\title{
KALISPEL TRIBE OF INDIANS WILDLIFE MITIGATION AND RESTORATION FOR ALBENI FALLS DAM: FLYING GOOSE RANCH PHASE I
}

\author{
Prepared by: \\ Christopher Merker \\ Upper Columbia United Tribe
}

\author{
Prepared for: \\ Joe DeHerrerra, Project Manager \\ U.S. Department of Energy




\section{TABLE OF CONTENTS}

\subsection{INTRODUCTION}

2.0 PROJECT DESCRIPTION
2.1 Scope of Project
2.2 Objectives
2.3 Workplan

3.0 METHODS

3.1 General

3.2 Habitat Evaluation Procedure

\subsection{RESULTS}

\subsection{DISCUSSION}

5.1 Implementation

5.2 Budget

\subsection{SOURCES}

\subsection{APPENDICES}

7.1 Habitat evaluation procedures for the Flying Goose Ranch

7.2 Fisheries and water quality survey of Flying Goose Ranch

7.3 Wetlands engineering design for Flying Goose Ranch 


\section{LIST OF FIGURES}

TITLE

PAGE

Figure 1. General locatron of Flying Goose Ranch Wildlife

Mitigation Project

Figure 2. Soils map of Flying Goose Ranch

Figure 3. Locations of HEP sites on Flying Goose Ranch

\section{LIST OF TABLES}

Table 1. Albeni Falls Dam losses

Table 2. Albeni Falls Dam habitat unit (HU) losses and

projected with project management

Table 3. $\quad$ Forest inventory data for Flying Goose Ranch and adjacent U.S.

Forest Service land as model comparison

Table 4. Objective and cost by year of project 


\subsection{INTRODUCTION}

This report is a recommendation from the Kalispel Tribe to the Northwest Power Planning Council (NPPC) for wildlife habitat mitigation for the extensive habitat losses caused by Albeni Falls Dam on and near the Kalispel Indian Reservation.

NPPC's interim wildlife goal over a 10 year period (1989-I 999) for the Columbia hydropower system, is to protect. mitigate and enhance approximately $35 \%$ of the lost habitat units identified in Table 5 of the Wildlife Mitigation Rule (89-35). During the coming ten years, NPPC will focus on higher priority wildlife resources. An orderly and predictable pace for implementation is important. Our recommendation will address all these items.

The six hydropower mitigation projects listed in Table 5, of the Wildlife Rule presented habitat unit changes due to the project. These changes were accepted as reasonable by NPPC as starting point for mitigation. Albeni Falls Dam losses were excerpted from Table 5 of the Wildlife Rule, and are shown below. Also shown are those estimated with project habitat units which will be enhanced on the Kalispel Indian Reservation. These were reported in Albeni Falls Wildlife Protection Mitigation and Enhancement Plan, (Martin et a/. 1988).

Table 1. Albeni Falls Dam Habitat Losses

\begin{tabular}{lcc} 
Target Species & Total Habitat Units (HU) & Kalispel Tribe (HU) \\
\hline Mallard & 5,985 & 230 \\
Redhead duck (winter) & 3,379 & 0 \\
Canada goose & 4,699 & 450 \\
Bald eagle-breeding & 4,508 & 720 \\
Bald eagle-wintering & 4,365 & 720 \\
Black-capped chickadee & 2,286 & 100 \\
Yellow warbler & 171 & 70 \\
White-tailed deer & 1,680 & 160 \\
Muskrat & 1,756 & 40 \\
\hline Total & 28,587 & 2,490 \\
\hline
\end{tabular}


The above losses and methodology to estimate them were reviewed and developed by members of the Albeni Falls Work group:

Idaho Dept. Fish and Game

Northwest Power Planning Council

U.S. Army Corps of Engineers

U.S. Fish and Wildlife Service

U.S. Forest Service

Upper Columbia United Tribes

Kalispel Tribe

\begin{abstract}
Albeni Falls Dam is located on the Pend Oreille River near the Washington Idaho border, about 25 miles upstream of the Kalispel Indian Reservation. The dam controls the water level on Lake Pend Oreille. The lake was formerly the center of subsistence use by the Kalispel Tribe. Flooding of wetlands, and water level fluctuations both on the lake and downstream on the river, has had adverse impacts to wildlife and wildlife habitat. This proposal addresses about one half the lost habitat units $(\mathrm{HU})$ as credited to the Kalispel Tribe. The proposal is designed to replace in-kind habitat on-site.
\end{abstract}

In-kind habitat i.e., riparian forest and wetland very similar as that identified by the Albeni Falls Wildlife Protection, Mitigation and Enhancement Plan (Martin et. al, 1988) will be replaced. It would be on-site as the purchase opportunity involves land sharing a common boundary with the reservation, along the Pend Oreille River downstream from Albeni Falls Dam. This is important because management costs will be lower and habitat benefits higher. For example, by creating a water control structure to enlarge a wetland on the purchased land, the water can be impounded in such a way to flood a portion of existing reservation. Wetlands will be increased without additional land costs.

An extensive process was followed to formulate and prioritize wildlife resource goals. The Kalispel Tribal Council provided guidance in terms of opportunities on-site. To prioritize specific goals the Albeni Falls Work Group and the Columbia Basin Fish and Wildlife Authority Wildlife Committee were consulted. From this process, the top priority goal for the Kalispel Tribe is: 
Protect and develop 1,260 habitat units of riparian forest and shrub, and freshwater wetlands, to mitigate losses resulting from reservoir inundation and river level fluctuations due to Albeni Falls Dam. Indicator species benefiting include mallard, bald eagle (breeding and wintering) Canada goose, black-capped chickadee, yellow warbler, white-tailed deer, and muskrat.

To meet this priority goal, the Flying Goose Ranch was proposed as a mitigation site in an earlier UCUT report (Merker and Scholz 1990). The Albeni Falls Work Group ranked this project as first priority for 1990. The Columbia Basin Fish and Wildlife Authority's Wildlife Committee (CBFWA) ranked this as one of three projects to be implemented using 1990 BPA wildlife mitigation funding. The proposal was then submitted to the joint BPA/CBFWA Implementation Planning Process, commonly referred to as IPP. This process is conducted by the BPA - appointed Scoping Group. The Scoping Group first created criteria, and a scoring process, by which to rank all projects submitted for wildlife mitigation under the Wildlife Rule. The first projects were submitted for consideration in Fiscal year 1991. Of 32 projects submitted, the Pend Oreille Wetlands/Flying Goose Ranch proposal was ranked number three in importance by the Scoping Group in December 1990. The list and scoring criteria were then submitted to the BPA Policy Review Group (PRG). PRG reviewed the results and accepted it without changes. In addition they funded a detailed design analysis, the result being this report. Finally in January 1991 the Northwest Power Planning Council voted 7-1 directing BPA to purchase the Flying Goose Ranch.

Much of the detailed proposal submitted by Merker and Scholz (1990) remains unchanged as far as a management plan, and so will be the basis of this report. However additional information was required by BPA, including baseline Habitat Evaluation Procedure (HEP) inventory, detailed management objectives, hazardous materials survey and National Environmental Policy Act (NEPA) review. BPA conducted, or will conduct, the latter two items under a separate cover, while UCUT addressed the former and they are reported here. 


\subsection{PROJECT DESCRIPTION}

\subsection{Scope of Work}

The construction of Albeni Falls Dam in 1951 inundated 6,617 acres of wetlands once used by the Kalispel Indian Tribe. In addition, fluctuations in water levels both above and below the dam. destroyed riparian habitat and precluded the reestablishment of riparian plant communities. Finally, habitat loss occurred 40 years ago and cumulative wildlife losses have been extensive. These factors resulted in both direct and indirect losses of wildlife.

Acquisition of a $\mathbf{4 4 0}$ acre floodplain ranch directly adjacent to the Pend Oreille River and Kalispel Indian Reservation is the basis of this proposal. The land has been zoned Rural Acreage-Investment by Pend Oreille County. Recreational development on this land is considered "highest and best use" by the county. The land will be placed in tribal trust with Bureau of Indian Affairs, and dedicated to wildlife. In this way it will be secure from development taking place along the river corridor.

The plan is designed in three steps:

\section{Acquisition \\ Enhancement \\ Operations and Maintenance/Monitoring and Evaluation}

Acquisition will prevent further degradation by cattle grazing, will prevent sale and recreational home site development, and be consistence with wildlife management objectives of the Kalispel Tribe. BPA has negotiated with the landowner and a selling price has been agreed upon. As of this writing, terms of sale had been negotiated. and a sale purchase option signed. Full fee simple purchase remains to be consumated.

\section{Enhancement will follow acquisition. It will consist of repaining an existing dike} and water control system to expand and restore fresh-water wetlands, repair an eroding shoreline, convert an over-used cattle pasture to optimum goose brood habitat, restore a flood plain, black cottonwood ecosystem and an upland mixed deciduous-coniferous forest. The objective is to maximize the benefits to wildlife by restoring an over-grazed 
ranch to optimum wildlife habitat, and credit the Habitat Units towards Albeni Falls Dam impacts.

Operations and maintenance $(0 \& M)$ and monitoring and evaluation $(M \& E)$ will be the third and final step in the plan. $0 \& M$ is needed to speed successional development of habitats, and to insure permanence of benefits from enhancement efforts. $M \& E$ is necessary to confirm results.

\subsection{Objectives}

Acquisition and development will protect and create a projected estimated 1260 HU's of mallard, Canada goose, bald eagle, white tailed deer, muskrat and riparian dependent passerine birds such as black-capped chickadee and yellow warbler as listed below in Table 2.

Table 2. Albeni Falls Dam habitat units (HU) losses to Tribe, and credited to project (modified from Martin et al. 1988).

\begin{tabular}{lccc} 
Target Species & $\begin{array}{c}\text { Kalispel Tribe } \\
\text { Losses }\end{array}$ & $\begin{array}{c}\text { Credited to } \\
\text { Project }\end{array}$ & $\begin{array}{c}\text { Current } \\
\text { HUs }\end{array}$ \\
\hline Mallard & 230 & 110 & 77 \\
Redhead duck & 0 & 0 & 0 \\
Canada goose & 450 & 190 & 42 \\
Bald eagle-breeding & 720 & 390 & 67 \\
Bald eagle-wintering & 720 & 390 & 81 \\
Black-capped chickadee & 100 & 50 & 15 \\
Yellow warbler & 70 & 30 & 2 \\
White-tailed deer & 160 & 70 & -2 \\
Muskrat & 40 & 30 & 61 \\
\hline Total & 2,490 & 1,260 & 345
\end{tabular}

${ }^{1}$ From this study; see Appendix 7.1 for full explanation.

2Not measured in this study. 


\section{2 . 3 GENERAL SITE DESCRIPTION}

The Kalispel Indian Reservation is in Pend Oreille County in northeast Washington State. The project area is in the valley of the Pend Oreille River, fronting on the river (Figure 1). The river is large, averaging 25,000 cfs annually, with spring peak average of 90,000 cfs. The Selkirk Mountains rise 6000-7000 ft above mean sea level on both sides of the valley.

The valley floor is well-developed from river alluvium. Wetlands are welldistributed in these rich deposits. Most of the valley floor is considered to be, or to have once been, wetland by Eastern Washington University Geography Department classification (Figure 1). The combination of wetlands, river, and north-south aligned mountains has resulted in an important migratory flyway for waterfowl and bald eagles. 


\section{Tri-County Wetlands 【nventory Jared (Provisional) Pend Oreille County}

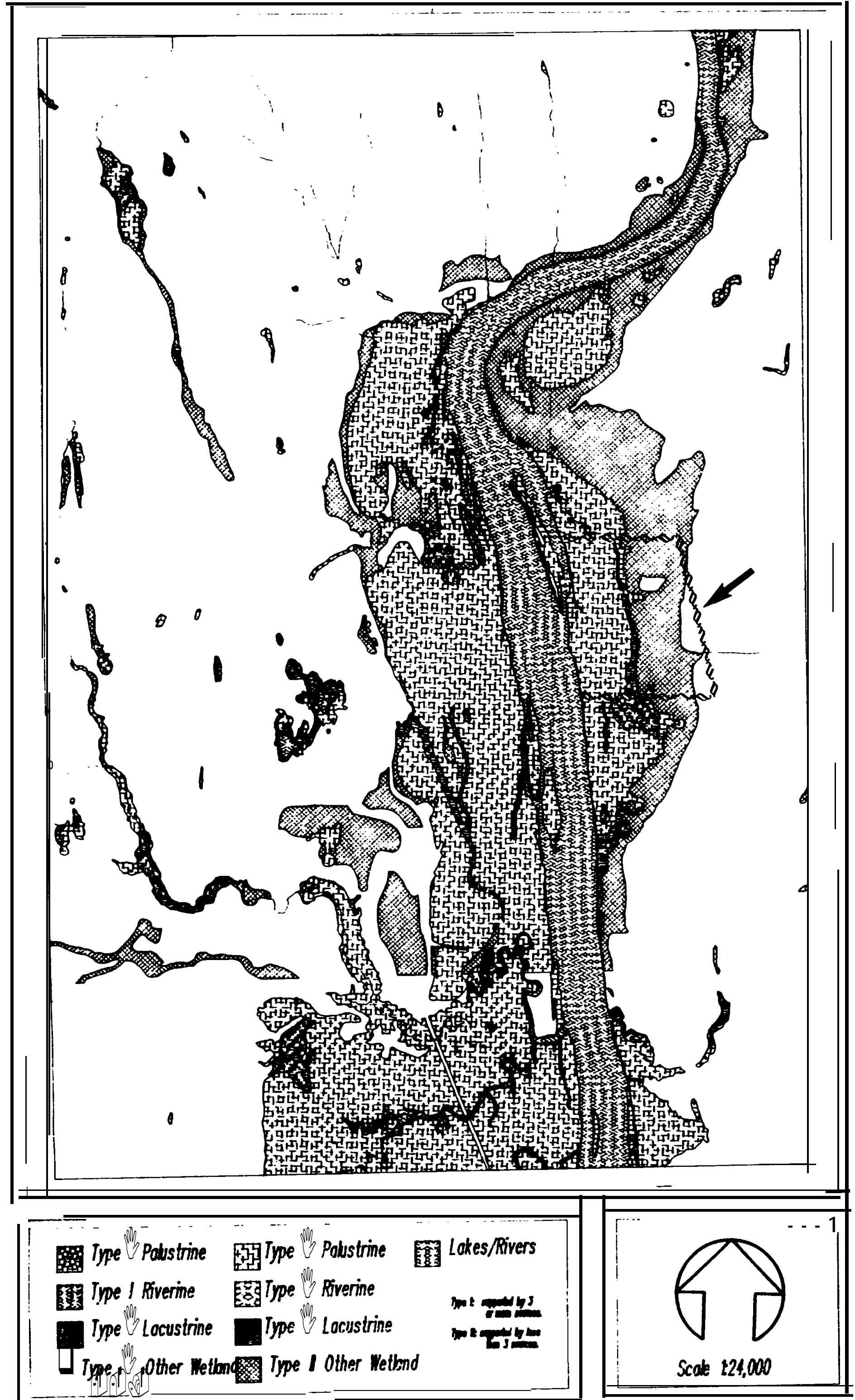

EASTERN WASHINGTON UNIVERSITY -Department of Urban and Regional Planning

Figure 1. General location of Flying Goose Ranch Wildlife Mitigation Project. 


\subsubsection{Climate}

In Pend Oreille County Area. summers are warm or hot in most valleys and much cooler in the mountains. Winters are cold in the mountains. Valleys are colder than the lower slopes of the adjacent mountains because of cold air drainage. Precipitation occurs in the mountains throughout the year, and a deep snowpack accumulates during winter. Snow melt usually supplies much more water than can be used for agriculture in the project area. In valleys summer precipitation falls during showers and thunderstorms. In winter the ground is covered with snow much of the time. Chinook winds, which blow downslope and are warm and dry, often melt and evaporate the snow.

In winter, the average temperature is $\mathbf{2 7}$ or 28 degrees $\mathrm{F}$ and the average daily minimum temperature is 20 or 21 degrees. In summer, the average temperature is 63 degrees and the average daily maximum temperature is 79 degrees. The total annual precipitation is about 27 inches. Of this, 9 to 11 inches, or 30 to 40 percent, usually falls in April through September. The growing season for most crops falls within this period. The average seasonal snowfall is about 62 inches at Boundary Dam and 70 inches at Newport.

\subsubsection{Soils}

Due to the importance of soils to wetland establishment and function, a brief description follows. Reference Figure 2 with the following text. Soil map number is in parentheses.

Anglen silt loam (12) 0 to 7 percent slopes: This very deep, moderately well drained soil is on terraces. It formed in a mantle of volcanic ash and loess over fine textured glacial lake sediments. The native vegetation is mainly conifers, shrubs, forbs and grasses. The average annual precipitation is 27 to 30 inches, the average annual air temperature is about 44 degrees $F$, the average growing season (at 28 degrees) is 90 to 110 days, and the average frost-free period is 75 to 105 days. Permeability is moderately slow. Available water capacity is high. The effective rooting depth is 60 inches or more. Runoff is slow, and the hazard of water erosion is slight. Douglas fir, western larch, grand fir, ponderosa pine, lodge pole pine, and western white pine are the main woodland species on this unit. 
If the stand includes seed trees. natural reforestation of cutover areas by Douglas fir, western larch, grand fir. ponderosa pine, lodge pole pine, and western white pine occurs periodically. Reforestation can be accomplished by planting Douglas fir, western larch, or ponderosa pine seedlings. When openings are made in the canopy, brush species that are not controlled invade and delay the establishment of natural and planted reforestation species.

This unit is suited to grazing and browsing. The forest understory is mainly Oregongrape, pinegrass, alder, common snowberry, thimbleberry, bluegrass, ceanothus, pachystima, mountain brome, rose, willow, and creambush oceanspray. Overgrazing causes the desirable plants, such as pine grass, rose, mountain brome, and creambush oceanspray, to decrease in extent and the less desirable plants to increase. Seeding suitable plants in recently disturbed areas can help to control erosion and provide desirable forage. Broadcasting is the most effective seeding method.

Borosaprists (22) ponded: These very deep, very poorly drained soils are in upland basins and on the perimeter of lakes and beaver ponds. They formed in organic material over alluvium derived dominantly from volcanic ash. Slope is 0 to 2 percent. The native vegetation is mainly wetland forbs and grasses, including rushes, sedge, cattails, and reeds. The average annual precipitation is 27 to 35 inches, the average annual air temperature is about 41 degrees $F$, and the average growing season is 60 to 110 days.

No single profile is typical of these soils. In one commonly observed in the survey area, however, the surface layer is black muck about 12 inches thick.

Permeability is moderate. Available water capacity is very high. The effective rooting depth is limited by a seasonal high water table that is 1 foot above the surface from October through June. Runoff is ponded, and water erosion typically is not a hazard. This unit is used for watershed and wildlife habitat. It provides good habitat for waterfowl. In summer, when the water table is below the surface, livestock graze in some areas.

Cusick silty clay loam (38): This very deep, somewhat poorly drained soil is in basins. It formed in fine textured glacial lake sediments. Slope is 0 to 3 percent. The 


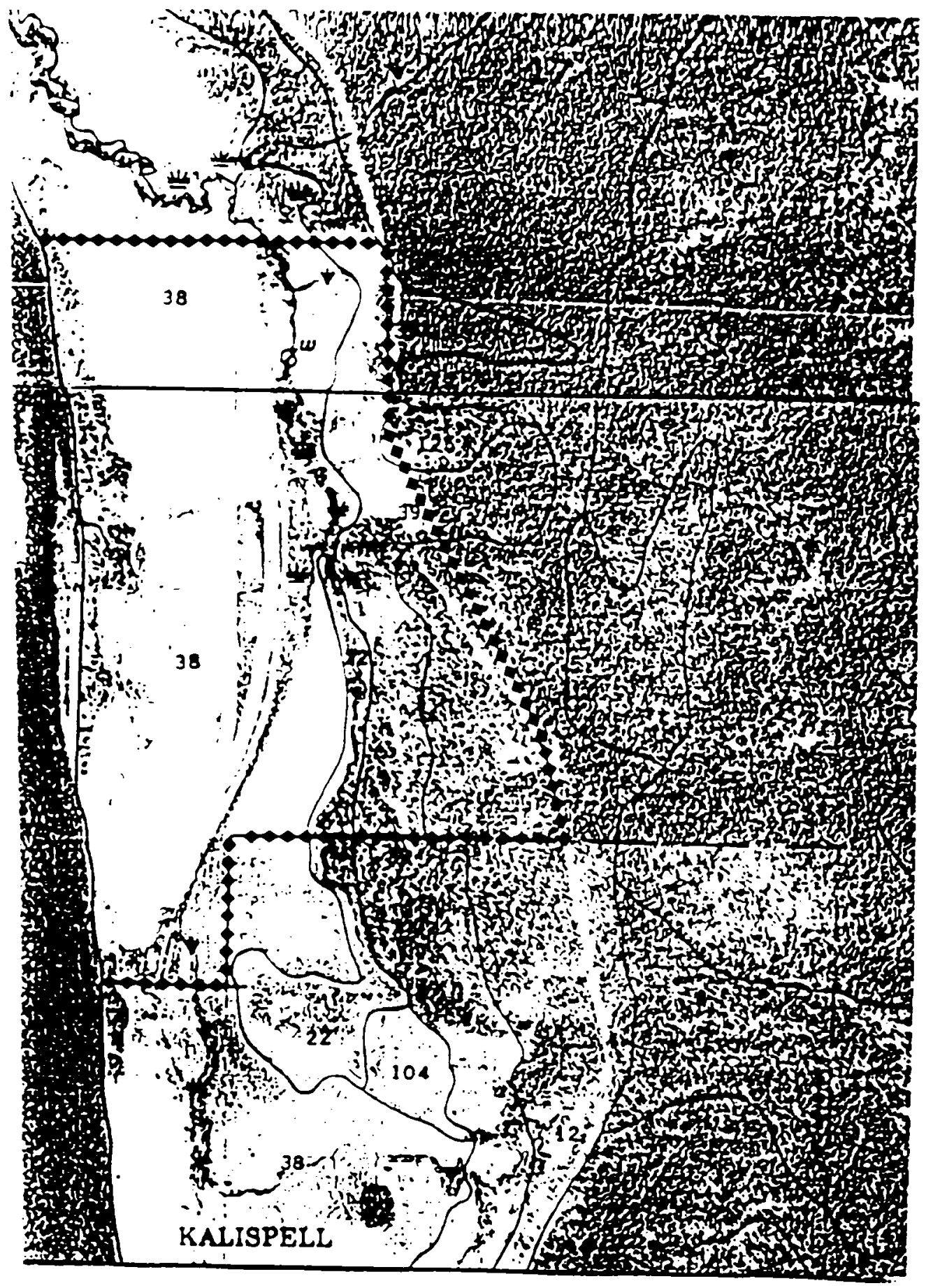

Figure 2. Soils map of Flying Goose Ranch 
native vegetation is mainly shrubs, forbs. and grasses. The average annual precipitation is 25 to 27 inches. the average annual air temperature is about 44 degrees F. the average growing season (at 28 degrees) is 90 to 100 days, and the average frostfree period is 75 to 105 days.

Permeability is very slow In the Cusick sod. Available water capacity is high. The effective rooting depth is limited by a perched seasonal high water table within a depth of 2 feet from November through April. Runoff is very slow. and the hazard of water erosion is slight.

This unit is suited to non Irrigated and irrigated oats and grass-legume hay. The main limitation is the seasonal wetness. A tillage pan forms if the soil is tilled when wet.

Dalkena fine sandy loam (39) 0 to 7 percent slopes. This very deep, moderately well drained soil is on terraces. It formed in glaciofluvial deposits over clayey glacial lake sediments. The native vegetation is mainly conifers, shrubs, forbs, and grasses. The average annual precipitation is 25 to 30 inches, the average annual air temperature is about 44 degrees $F$, the average growing season is 90 to 110 days, and the average frost-free period is 75 to 105 days.

Permeability is moderate to a depth of 30 inches in this Dalkena soil and slow below that depth. Available water capacity is high. The effective rooting depth is limited by a perched seasonal high water table at a depth of 2 to 3 feet from February through April. Runoff is slow, and the hazard of water erosion is slight. Douglas fir, ponderosa pine, and western larch are the main woodland species of this unit.

\subsection{METHODS}

\subsection{General}

Habitat Evaluation Procedures (HEP) were applied to measure the baseline condition. HEP was the standard loss estimator in all hydro loss statements submitted to the NPPC. BPA required its use on a project specific basis for increased detail and accuracy on projects accepted into the advance design phase. 
The Bureau of Indian Affairs (BIA) Forestry Branch at the tribal headquaners provided color stereo aerial ohotographs. Habitat types were delineated on mylar overlays, then digitized using program ROCKWARE DIGITIZE for determination of area.

BIA Forestry Brancn. U.S. Fish and Wildlife Servtce Wetlands Enhancement, and River Masters Engineerıng personnel all toured the site for suggestions and feasibility of management practices. Their comments and knowledge guided management suggestions, estimates of success and costs.

The permit process for work within wetlands can be extensive. The following agencies were contacted and found to have jurisdiction: U.S. Army Corps of Engineers, Washington Departments of Wildlife and Ecology. Following this step, if was decided to retain a protessional engıneerıng group. River Masters Engineering mapped wetland basins, designea physical structures, and identified alternatives. This should streamline the permitting process.

UCUT fisheries personnel conducted a preliminary fisheries survey of the interior slough suing a backpack electroshocker, as well as a water quality survey using a Hydrolab Scout II.

BPA conducted a hazardous material survey as part of the NEPA process. Results are not reported here, but are on file in their Portland Office.

To properly recreate the riparian forest type, an undisturbed stand is desired as a model. We were fortunate in finding such an area immediately north of the project site. It is owned by the U.S. Forest Service and although it has received some level of grazing, it appeared to never have been farmed or logged. We took note of species composition, density and juxtaposition.

\subsection{Habitat Evaluation Procedure (HEP)}

The objective of the Habitat Evaluation Procedures conducted on the Flying Goose Ranch was to rate the quality of lands being considered for easement and management as mitigation for losses to wildlife due to damages caused by construction of Albeni Falls Dam. The product of the baseline survey will determine the number of "Habitat Units" $(1$ H.U. $=1$ acre of optimum habitat, or e.g. 2 acres of habitat rated at 
0.5) currently available for individual indicators species, and the amount that will become available with management. Indicator species were used to determine the habitat quality ratıng and available habitat units. They were bald eagle, Canada goose, muskrat, black-capped chickadee. yellow warbler, and mallard. Martin et al. (1988) also used white-tailed deer. I chose not to use it due to its very wide ecological amplitude. The other species, being more dependant on specific habitats, are better indicators of habitat condition. I believe that with habitat management for them, deer will respond positively.

An interdisciplinary evaluation team was assembled. A Habitat Evaluation Procedures Manual was created to aid the team in rating the quality of the habitat. This manual provided the team with Habitat Suitability Models which described life requisites for eacn Indicator species. This enabled the team to derive a number value between 0.0-O corresponding to the quality of the habitat. i.e. the habitat suitability index $(\mathrm{HSI})$. The team conducted the site surveys and collected data on habitat type, quantity, quality, and wildlife use under existing conditions at established sites (Figure 3).

For a full explanation of the HEP process on this project, including models, data collection and interpretation, see Appendix 7.1. 


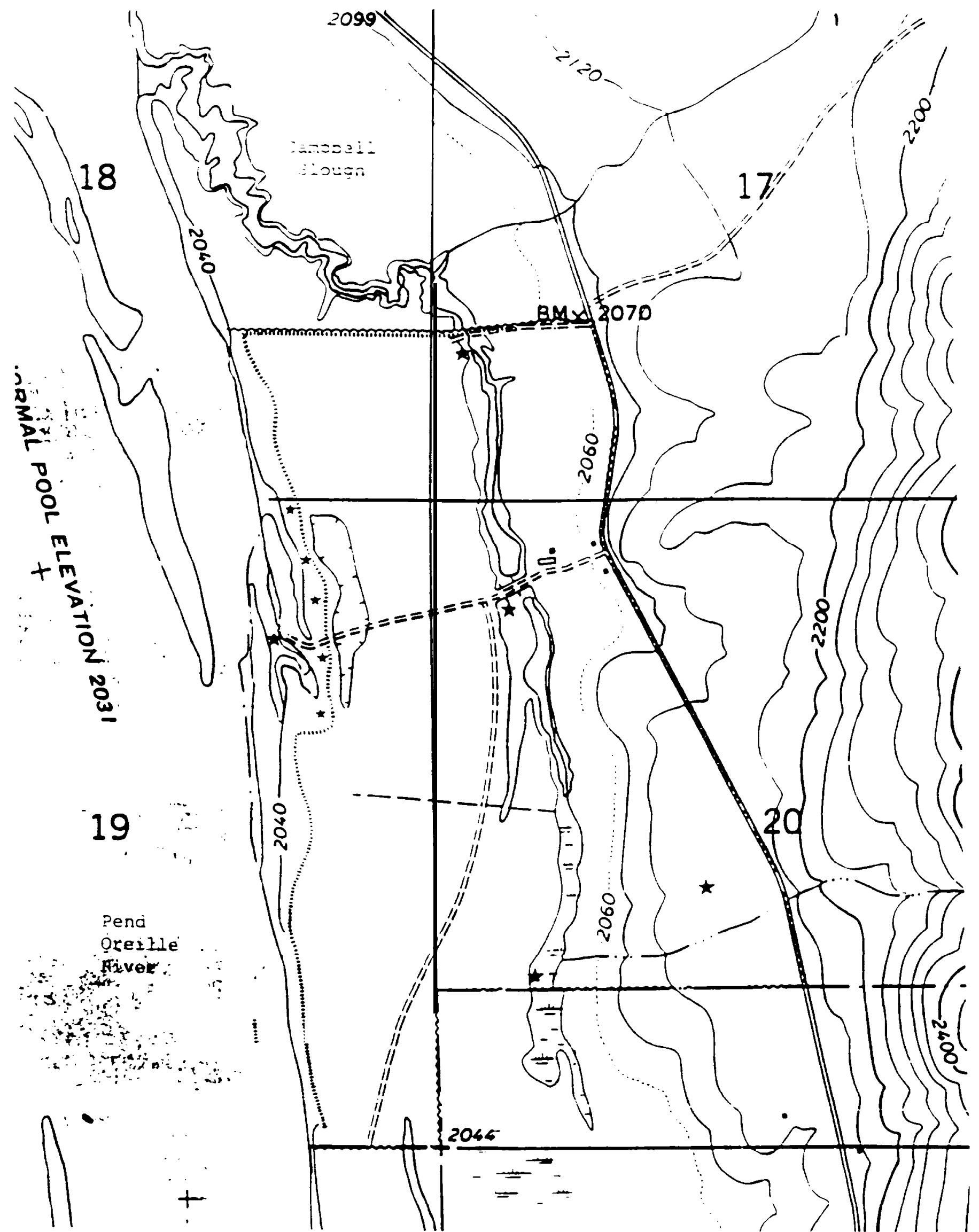

Figure 3. Habitat Evaluation Procedure (HEP) sitesusefor baseline condition, and futures monitoring, at Flying Goose Ranch Wildlife Mitigation Project. 


\subsection{RESULTS}

Following collection of field data, Habitat Suitability Indices (HSI) were calculated from models, and multiplied by acres of habitat type. The resulting Habitat Units are presented by Indicator species. This is the baseline. or current, HU's for the project area. See Section 7.0 (Appendix 7.1) for a full explanation of HEP results, and identification of limiting factors. See Section 5.0 DISCUSSION for detailed explanation of limiting factors that will be targeted under a management plan based on HEP results.

Results of a preliminary fisheries and water quality survey are presented in Appendix 7.2. In general the slough seems to support a very limited population of pumpkinseed sunfish (Lepomis gibbosus). This is probably due to the abundant emergent macrophyte vegetation. primarily cattail (Typha), and the slough bottom in an anoxic condition.

Results of the wetlands engineering consultation are presented in Appendix 7.3. This effort identified existing and potential wetland elevations and area, and detailed drawings on water control structures, placement and siting. The results of this consultation will be used to apply for necessary permits to work in wetlands. This report will be used as basis of need for the permits.

Four forested sites on the ranch were inventoried of shrub and tree species (Table 3). Two riparian forest (HEP site2) and two mixed forest (HEP site 10 and "roadside buffer") were sampled. All sites were subject to grazing. The adjacent USFS forest was use as an undisturbed control comparison. Roadside buffer and riparian forest on project were characterized by an almost total lack of tree and shrub reproduction. The stems per acre at HEP site 2 compared to USFS samples showed great differences. The USFS data will be useful in trying to reconstruct a large riparian forest on project. No undisturbed mixed forest could be found locally. Stems per acre are probably higher due to preponderance of unpalatable (to cattle) conifer component.

The Washington Department of Wildlife has mapped "critical waterfowl nesting" areas under its Priority Habitat and Species Program. The project shoreline, and Campbell Slough immediately to the north, have been so designated. 
Table 3. Forest inventory data for flying Goose Ranch and adjacent U.S. Forest Service land as model comparison.

\begin{tabular}{|c|c|c|c|c|c|}
\hline Site & $\begin{array}{l}\text { Dominant } \\
\text { overstoty }\end{array}$ & $\begin{array}{l}\text { Mean } \\
h t(F t)\end{array}$ & $\begin{array}{c}\text { Mean } \\
\text { dbh(in) }\end{array}$ & $\begin{array}{c}\text { Canopy } \\
\text { Coverage }(\%)\end{array}$ & $\begin{array}{c}\text { Stems } \\
\text { Acre }\end{array}$ \\
\hline \multicolumn{6}{|c|}{ Flvina Goose } \\
\hline \multicolumn{6}{|l|}{ Ranch } \\
\hline HEP2a & cottonwood & 39.0 & 9.1 & 91.9 & 100 \\
\hline HEP2d & cottonwood & 43.4 & 20.7 & 90.4 & 100 \\
\hline HEP 10 & mixed forest & 65.0 & 14.8 & 94.0 & 1800 \\
\hline $\begin{array}{l}\text { Roadside } \\
\text { buffer }\end{array}$ & mixed forest & 74.3 & 16.2 & 89.4 & 400 \\
\hline \multicolumn{6}{|c|}{ U.S. Forest Service } \\
\hline Mature & cottonwood & 77.0 & 18.1 & 98.7 & 300 \\
\hline Pole & cottonwood & 28.4 & 3.6 & 99.4 & 900 \\
\hline
\end{tabular}




\subsection{DISCUSSION}

\subsection{Implementation}

The seven indıcator species were chosen to gauge the current condition of the existing habitat. as well as to set goals for future improvement. The condition of the existing habitat was measured through the HEP process discussed earlier. In this section, discussion of each species and respective habitat management tasks is by habitat type. The HEP variables are used as a basis of management. However, also included are additional management techniques not included in the model that are important to the species. as well as to increase both habitat and wildlife diversity on project.

Recently the Washington Department of Ecology developed a report series to spur the development of policies and standards for wetlands protection. Most projects reviewed did not meet mitigation goals due to poor planning, implementation and/or monitoring. Estimates of historic wetland loss on the state level are $50 \%$, while local losses may approach 98\% (Canning and Stevens 1989). Successful mitigation in the future is imperative to provide a myriad of functions such as fish and wildlife habitat, flood control, shore stabilization, sediment and waste control, water supply, both surface and ground, and recreation opportunities. More complex wetlands types, such as forested and shrub-scrub. were lost and not replaced, or "replaced" by emergent or open water types (Castelle et al. 1992). Poor success for forested wetlands is partly due to more expensive inputs, hydrologic requirements and slow maturation (Kussler and Kentula 1990). However, these should not be considered constraints, but opportunities for innovative management and to further our knowledge of this neglected aspect of wetland science. As over 2314 acres, or 35\% of total losses due to Albeni Falls Dam were forested (Martin et al. 1988) we must make efforts to replace these types. The Flying Goose Ranch offers the opportunity to replace a portion of these losses.

Land acquisition is the first and most important step in the management process. BPA recently completed a part of the process, begun by the tribe, to negotiate terms and conditions on the sale of the ranch. In August 1992 BPA and the landowner signed a sale option. Full acquisition is planned "as soon as possible" (See Appendix 7.4 letter from J. Luce, BPA to A. Scholz, UCUT). 
Following acquisition. permanent management practices can be implemented. Numerous site visits, onservations of wildlife. the HEP process and wetlands engineering all were used to formulate objectives. These objectives will be met by performing a series of tasks. The order or level of implementing the tasks was arranged by a variety of factors such as ease of implementation, costs, permit constraints and urgency. At either end of the spectrum. for example, are cessation of cattle grazing and restoration of riparian forest on 100 acres. The former is most urgent, due to its severe impact to the existing riparian forest and shoreline. It is clear in that by not doing something, i.e. grazing cattle, we allow the forest, shoreline, wetlands and grassy field to begin recovery. Conversely, riparian forest restoration will be a very interactive, money and time-dependent endeavor.

\section{Level I. Objectives and Tasks}

\section{Objective 1.1 Baseline Inventory}

Baseline wildlife populations will be assessed prior to, and during, habitat development. Populations will be assessed by target species guild. For example, bald eagle winter use will be assessed by total counts from November-April. The entire area will be surveyed using binoculars and spotting scope. Waterfowl response will be measured by spring pair and lone drake counts on wetlands, using binoculars from dike and canoe access. Changes in song bird populations (including black-capped chickadee and yellow warbler) will be determined initially, and monitored through the project, using line transect methods twice monthly throughout the year. These methods, as well as others deemed necessary, will continue through the monitoring phase (Level IV Task IV.I).

\section{Objective 1.2 Cattle Grazing}

\section{Task 1.2.1 Cessation}

All grazing will cease at the end of the 1992 lease agreement. Crumbling shoreline banks, damaged dike, and degraded and declining riparian forest are all a result of unrestricted season-long grazing for many years. Grazing may be used in the future on a limited basis to meet specific goals for wildlife, e.g. to open up dense stands 
of cattails, or to prepare for planting of woody vegetation. Grazing will not occur beyond the dike along the river shore. or in any habitat type dominated by aspen or black cottonwood. The latter is so highly preferred that cattle seek it out first, and even eat fallen leaves (Sedgewick and Knopf 1991).

\section{Task 1.2.2 Modified Use}

If cattle grazing is used in the future, electric fence will be used, at the lessees expense, to contain the livestock. No new barbed wire fence will be established. Old interior fences may be removed. Perimeter fences will be repaired and retained. Barbed wire is a potential hazard to birds and deer, and to some extent moose, which are locally increasing.

\section{Objective I.2 Bank Repair and Riparian Restoration}

About 1500' of river bank. beginning at the south boundary, is severely degraded by erosion. Cattle grazing has removed most woody vegetation. Without protection the banks are sloughing in high spring river flows.

\section{Task $1.1 \quad$ Initial Repair}

Cuttings of dormant black cottonwood, red-osier dogwood and willow will be collected on adjacent tribal lands in February-March. They will be at least 1/2" in diameter and 3' long. All side branches will be stripped and the cuttings driven into the ground as far as possible using a mallet and rebar for pilot holes.

\section{Task $1.2 \quad$ Long Term Repair}

Following one year of cattle restrictions and plantings, results will be noted as to bank stabilization. If sloughing continues then the following will be implemented. A log boom consisting of cedar logs will be attached end to end and anchored immediately offshore. Used tires will be threaded over the logs with additional tires suspended below. This will create an effective and cost effective breakwater, as an alternative to expensive and disruptive rip-rap. The purpose is to mitigate wave action on the exposed shoreline. Biological methods include further planting of shrubs and trees, and use of cut conifer trees as bank protection. Planting of unrooted cuttings from local 
black cottonwood and willow species will be made directly into the eroding bank following breakwater placement. Both species root well in moist/wet soils. The use of conifers cut and anchored along the exposed bank will further slow erosion behind the log boom. This technique has been employed in central Oregon on eroding streambanks with good success (pers. obs.). The conifer supply can be tops from local logging slash or thinning operations. The conifers are placed large end upstream/upbank. and anchored. This not only slows wave action, but also traps sediments, allowing vegetation growth. Additional benefits to wildlife included amphibian and furbearer shelter. and fish rearing habitat.

\section{Objective $1.3 \quad$ Site Cleanup}

The farm buildings nave been investigated by consultants to BPA (Cordery-Colter 1991). Some diesel fuel-stained soil was found. A building foundation had elevated leveis of copper, possibly due to electrical wiring. However no serious hazardous wastes were found. Refuse levels are high as many abandoned vehicles are present. Unusable outbuildings are also present. Powerlines need modification, maintenance or removal.

\section{Task 1.3.1 Farm Site}

The Washington State Department of Ecology and Pend Oreille County will be contacted. Guidelines for clean-up, and the permitting process, will be pursued and implemented. With the exception of the house, equipment barn and grain storage, all other buildings and material will be removed, recycled, burned and/or buried. The house will be used as a field station, the barn for equipment storage, and the grain silos for seed. Scrap dealers will be contacted and offered the vehicles. The local fire departments will be requested to stand-by during burning operations. An operator with an appropriate-sized front-end loader and dump truck will be retained to do major disposal. Seasonal laborers are available through the Kalispel Tribe for hand clean-up of smaller items.

This would be an appropriate time to plan for public use. Immediately following clean-up, a small-capacity ( $\pm 10 \mathrm{car}$ ) parking lot will be established. A large interpretive sign will be created, explaining project purpose and sponsors. Basic repairs and 
upgraaes will also be made to the existing house for its use as a field station and interpretive center.

\section{Task 1.3.2 Powerlines}

The Pend Oreiiie PUD has been contacted regarding our plans. Specifically we discussed the existing powerlines on project. There are two major components of the system. The first is an old. non-functional line with mechanical switches once used to pump river water for irrigation. This line runs from the farm-site south to the south-west corner of the property. The PUD is willing to remove it, and so claim abandonment of responsibility. Some sound poles will be retained for raptor perching and nesting. The second line segment is live, and runs north from the farm-site. However, it is currently in standing water in the slough. Maintenance is a problem now, and will become more so in the future with increased water levels under wetland management. The PUD has tentatively agreed to move this line to an upland site if given a right-of-way (ROW). An ROW along the highway would be ecologically and economically desirable. Movement will be facilitated during wetland draw down during water control structure construction.

\section{Objective $1.4 \quad$ Hydrology}

Of ail the factors affecting wetlands, hydrology seems less well understood. Yet hydrology is probably the single most important factor in riparian bottomland forest restoratlon (Lea and Fredrick 1992; Kussier and Kentuia 1990). A common theme in literature review for this plan was the lack of attention to, and functional knowledge of, the Interrelationships between surface and groundwater hydrology, seasonal soil moisture, and wetland plant community responses. We will follow the guidelines of Richter (1992) to measure both surface flow and groundwater.

\section{Task 1.4.1. Surface Flow}

Guages will be installed on each water control structure around the project perimeter dike. This will allow determination of surface flow exiting the project. Knowing the mean quantity of seasonal water available will enhance management of both vegetation and wildlife. 


\section{Task 1.4.2. Ground Water Wells}

Determ!natlon oi ground water table depth and monthly fluctuations, before and after water control establishment. Is needed. "Sand Point Wells" will be established to monitor seasonal ground water levels and fluctuations. These are fairly cheap, about S150. and can be Installed by hand.

\section{Task 1.4.3. Tensiometers}

Measurement of degree of soil moisture of various depths (4", 18' and 24") will minimize irrigation needs but maximize plant establishment. Tensiometers will be established at each well point. and at planting sites.

\section{Objective $1.5 \quad$ Weed Control}

An undesireable plant survey was conducted for BPA by the Pend Oreiiie County Noxious Weed Control Board (Sorby et al. 1992). Class A Noxious Weeds and class BDesignate Noxious Weeds have mandatory control requirements. However, none were found on project. A number of Class B and Class C Noxious Weeds, as well as nonclassified "undesirable' plant species were found. Control is not required, but recommended. See Appendix 7.5 for a complete discussion.

\section{Task 1.5.1 Control and Maintenance}

Most weeds are the result of disturbance resulting in much bare gound due to intensive, season-long grazing. With removei or reduction of grazing, weeds such as bull thistle and muilein are expected to disappear as grass competition increases. Sorby et al. (1992) listed a comprehensive set of recommendations. We will work closely with the County Weed Board in implementing these recommendations (See Appendix 7.5). Foiiowtng control during implementation, regular spot maintenance control will occur during the 0 \& $M$ phase.

\section{Level II}

These objectives were identified primarily through the HEP process. They were believed to be the limiting factors to target species of wildlife and so are priority 
Implementatlon Items. From Appendix 7.1 they include the following with target species in parenthesis:

-. $\quad$ Increased percn tree size (bald eagle)

- $\quad$ Increased tree density in deciduous forest (black-capped chickadee)

- $\quad$ Construction of nesting islands (Canada goose)

-- $\quad$ Revegetation of river shoreline (Canada goose and muskrat)

-- Restoration of wetland shrubs (yellow warbler)

-- $\quad$ increased grass nesting cover (mallard)

-- Seasonally flooded wetland type (mallard)

\section{Objective II.1 Increased Perch Tree Size}

\section{Task II.1.1 Thinning From Below}

Using Bureau of Indian Affairs Forestry Division assistance, accepted techniques will be applied to speed tree growth. Currently, the mixed coniferous-deciduous forest has been "high-grade" logged over the years. This removes the largest and/or more superior trees. Instead. we will cruise and mark the largest and best trees for retention. Through a "thinning-from-below" process we will then remove competition to these trees to stimulate faster growth. An example of this can be seen on tribal land immediately south of the project forest.

\section{Objective II.2 Increased Deciduous Tree Density}

\section{Task II.2.1 Aspen Release}

Within the mixed forest and task II.1.1. described above, we will encourage aspen. This will be done by removing competing vegetation, especially conifer, from within and near aspen stands. Aspen prefers full sunlight and higher moisture than conifers. Stands should sucker well and expand following removal of competition.

\section{Task II.2.2 Cottonwood Enhancement}

Within the riparian forest, two techniques will be employed to increase deciduous tree density. The primary species here is black cottonwood. Aspen is present but at 
lower densities. Restrictionremoval of cattle grazing has been discussed earlier. An indication of cottonwood sproutıng potential. and cattle impacts, were clear in 1992. Cattle were introduced in July, later than normal release in May. This gave the cottonwood and aspen 2 months of undisturbed growth. Suckering was profuse. However. upon Introduction. cattle immediately sought out and removed most ail suckers prior to any noted Impacts to the tall timothy grass, a preferred grass species.

Following the restriction of livestock grazing, planting of cuttings will commence (see Task 1.2.1 for detail). A low density (100 stems/acre) planting will help speed both Increased density and mean height following many years of cattle impacts. The planting density was chosen to speed. and to give some assurances that, the recovery will approach 900 stems/acre in an undisturbed young stand, versus the current level of 100 stems/acre (see Table 3).

\section{Objective II.3 Nesting Islands}

island construction has proven to be very effective for increasing waterfowl nest success. Densities as high as 20-80 nests/acre have been reported due to security from predators (Burger and Webster 1964). Non-breeding and moulting adults, and flight-less broods are also expected to use the islands.

\section{Task II.3.1 Waterfowl Islands}

We plan to construct seven islands. Construction is best and most cheaply accomplished by using an excavator to pile soil, and a front-end loader to move soil within the wetland basin. This will be done during the summer dry season. The islands will be compacted, seeded, and allowed to stabilize prior to basin flooding.

Each island will be a approximately of $70 \times 300 \mathrm{ft}$., and $3 \mathrm{ft}$. above high water as well as $100 \mathrm{ft}$. from shore with a '50 wide 4' deep moat, to deter predators.

\section{Objective II. 4 Shoreline Revegetatlon}

The shoreline has been designated "critical waterfowl nesting" habitat. its restoration will help meet state and federal duck populations recovery goals. 
The current shoreline is mostly devoid of herbaceous cover due to cattle grazing. I looked at the adjacent U.S. Forest Service parcel as a comparison and found that below the normal high water mark (about 2040' msi) sedges and rushes (Eleocharis and Carex spo.) dominated. Patches of Scirous were present at mean water level (August). Grasses and forbs comprised the remainder. Canopy coverage of herbaceous plants was $60-90 \%$. Above the mean high water level, red-osier dogwood and cottonwood were invading to the water line.

\section{Task II.4.1 Woody Plantings}

Planting of cottonwood and dogwood cuttings will be done at 100 stems/acre on 10 acres to the water line.

\section{Task II.4.2. Bulrush Plantings}

Using a front-end loader, Scirous clumps will be transplanted to the mean water level in August. One clump per 300' of shoreline is the goal. Without livestock, expansion can be expected along the shoreline. Other grasses and sedges will not be planted, as they are expected to invade rapidly following cessation of cattle grazing.

\section{Objective II.5 Restoration of Shrub Swamp}

Drainage, farming and grazing activities have ail impacted riparian shrubs. These shrubs included red-osier dogwood, willow and to some extent, hawthorn. The latter is included, though not a wetland obligate, due to its valued structure and fruit. Two hawthorn species are present on project: Craetequs douglasii and $\underline{C}$. columbiana.

\section{Task 11.5.1 Wetland Shrub Planting}

Cuttings of willow and dogwood, and rooted plants of hawthorn will be used: the former two just below, at, and just above the waterline, the latter as an upland screen. This will occur on about 10 acres along the east edge of the slough north of the farm site. This area is currently very open. Revegetation here will shelter much of the project from audio and visual intrusion from the highway. This goal is dependent on, and will be accomplished, when water control is firmly established. 


\section{Objective 11.6. Increased Grass Nesting Cover}

The mallard model clearly showed that nesting cover was lacking (nesting cover $\mathrm{HSI}=0.3$. This will be easily remidied by cessation of cattle grazing. Tall residual grass will result in much higher $\mathrm{HSI}$.

\section{Level III}

This third level of effort Includes the most detailed and scaled items of implementation. Engineering, costs and permitting are all more complex. However, the rewards are greatest of all, due to the conversion of the lowest valued cover type, tame pasture. to two of the highest valued types. riparian forest and emergent paiustrine wetland. The acreage Involved. about 200 acres, is also extensive and represents about one-half of all project lands. The primary constraint is agency permitting, a process of unknown length. Time to maturation to full wildlife benefits in restored forest will also be a significant factor. Hence the Level iii listing.

\section{Objective III.1 Wetland Restoration}

In the 1950's. $10,000 \mathrm{ft}$. of perimeter dike, ditches and one-way flap gates were constructed and installed. This allowed the drainage and clearing of over 200 acres for farming and livestock purposes. Today however, we can take advantage of those appurtenances and use them to restore old and create new wetland. An extensive engtneering survey has been completed by a professional group (Appendix 7.3). it is the basis of the following discussion of management items, and costs. it is also an essential exhibit for the permitting process.

\section{Task III.1.1 Permits}

This report with Appendix 7.3 will be submitted to the following agencies for the appropriate permits to work within wetlands.

A. U.S. Army of Corps of Engineers: Section 404 Federal Water Pollution Control Act. This is necessary due to the goal of dredging material from a wetland, i.e. island instruction. Dredging fill for islands, and channels to improve water control, fish and waterfowl habitat may ail occur. Approval of this type of activity 
Is expected but may take 2-6 months of review. However, the projects positive wetland goals may qualify it for a "Letter of Permission" and thereby greatly shorten and simplify the process.

B. Washington State Department of Ecology: SEPA checklist, and Reservoir Permit Water Right.

I. State Environmental Policy Act requires all government agencies to consider the environmental impacts of a proposal before making decisions. Its primary purpose is to assist in identifying significant negative environmental impacts.

ii. Reservoir: To impound 10 or more acre feet of water, a reservoir permit Is needed. At maximum pool at 2042' msl, there is the potential to store 179 acre feet of water. This will be very low head, i.e. only about one foot. At all times a minimum of two feet of freeboard will be maintained below the top of the dike. All engineering guidelines as outlined in Appendix 7.3 will be followed.

C. Washington Department of Wildlife: a Hydraulics Project Application (HPA) needs to be approved prior to working within the slough. Protection of water flows and fish life is the primary purpose of an HPA.

\section{Task III.1.2. Water Control Structure Construction}

- Six structures are planned: five in the dike to pass water out of the project, and one in the rebuilt dike/road bisecting the interior slough (see Appendix 7.3 for full details). The structures will allow impoundment of an additional one foot of water within the lower interior slough. This will overflow into the existing pasture and flood an additional 113 acres creating new wetland. This additional water depth will also lend increased security to nesting islands built within the new wetland. Drawdown flexibility, and water flow patterns, will be greatly enhanced for increased wetland productivity. Management of seasonal wetlands, a limiting factor in the mallard model, will be a primary objective. The area of permanent wetland within the slough will also increase. This will offer greater security to flightless water fowl brood and moulting adults. 
Increasea depth wil also favor nesting diving duck species. especially to rehead ducks, by opening up dense stands of cattail.

Construction wil take about 173 hours of installation tıme. or 22 work days. This will need to be done during the drier season of August-October.

\section{Objective III.2. Riparian Forest Restoration}

Extensive losses of forested wetlands were caused by the Albeni Falls project. The United States Fish and Wildlife Service (USFWS) has identified these areas as unique and scarce on a regional basis (Sather-Blair cited in Martin et. al., 1988). In some western states, riparian losses have reached 95\% (Brinson et al. 1981). Knopf (1988) pointedly stated: "The lack of cottonwood regeneration is undeniably the most critical riparian conservation-Issue in the western states today." Bald eagles are dependant on this habitat for nesting, roosting and perching. Lost bald eagle HU's were greatest of all target species on Kalispel Reservation.

We propose to restore 60 acres of tame pasture to black cotton-wood-dominated forest, with an understory of willow and red-osier dogwood to be planted simultaneously. Local stock will be collected and rooted prior to planting. This will be done to increase survival, as the higher, drier interior of the pasture is to be planted. Cuttings will also be used as a comparison. Natural seeding potential will also be tested. During the summer prior to plantıng, 10 acres will be fallowed over each of 6 years to control weeds. The plantings will occur in the following spring.

Three approaches in establishing black cottonwood will be tried to maximize success rates. Initial test results will be used to select best methods to complete the restoration. The three methods are:

\section{Task III.2.1. Scrape and Seed.}

This will be tested immediately adjacent to the existing riparian forest. Fall tillage using a tractor-pulled disc will break up the sod. Spring runoff will be held on the tilled ground to kill competition and to wet the soil. Conditions then should be good for germination of wind-blown cottonwood seeds. This method has been very successful under proper conditions in eastern Colorado (M. Scott, pers. 
comm. 1. It simulates natural reproduction and establishment. Areas chosen need to oe adjacent to a seed source with a summer water table close to the surface. Surface irrigation greatly increases success rates. A gasoline-powered pump with 3" intake will be usea to transfer water from the river slough and spray it through stand-pipe sprinklers.

\section{Task III.2.2 Pole cuttings}

For best results, the guidelines to be followed for planting unrooted cuttings were outlined by Hoag et. al. (undated) for planting riparian areas in Idaho, and Swenson (1988) for New Mexico with project specific needs included.

- In year prior to planting. weaken pasture grass competition by intense grazing, herbicide or tillage.

- Collect cuttings in dormant season, remove all side branches, seal the top if necessary, store in cooler at $3-6^{\circ} \mathrm{C}$ until planting.

- $\quad$ Cuttings should be minimum of 1.53 " dbh -- larger is better.

- Length of cuttings should be great enough to reach mid-summer water table (about 3' deep on project), 3-10 long is recommended.

- Soak cuttings in water I-1 0 days prior to planting in April.

- $\quad$ Planting depth should be $1 / 2-2 / 3$ length of cutting for best soil-stem contact.

- For ease and greatest efficiency of planting, a tractor with an auger or steel rod, should be used to create a hole of sufficient size and depth.

- Planting supplements did not increase survival or performance (removal of competition was not addressed).

- $\quad$ Back fill the holes carefully to avoid air pockets.

- $\quad$ Remove all buds and stems as they grow from lower two-thirds of the pole. 
. Only one-nalf of the non-wetland pasture acreage will be planted. Randomized group plantings will be made with openings between to maximize edge.

\section{- Control competition}

\section{Task III.2.3 Rooted cuttings}

Plant materials will be cultured at the recently established native plants nursery in Cheney. This is a cooperatıve effort between Eastern Washington University and Cheney High Scool biology staff. A new greenhouse at EWU will allow culture of newly collected, and/or smaller. plants. Outplanting at the outdoor nursery at the high school will occur for one growing season. Growing capacity, and cultural knowledge, of native plants is limited. The mitigation project is an opportunity for UCUT, BPA. EWU and Cheney High School to meet that challenge, as well as holding down costs and offering educational opportunities.

\section{Task III.2.4 Irrigation and Costs}

A low capitolirrigation system. as designed and used by Bureau of Land Management, will be employed. To ensure initial plantings are successful. and to avoid costly replanting efforts, a drip system will be used in the first growing season following planting. The system consists of a 2500 gallon plastic tank, a timer to best apply water, $1 / 2^{n}$ delivery tube, $1 / 4^{\prime \prime}$ emitter tube. emitters and miscellaneous fittings. Cost for one unit to irrigate 2 acres is $\$ 2.000$. We will restore 10 acres/year. Planting will occur in clumps over one-half of the area. to leave open meadows in between plantings. If 10 acres per year will be planting, then 5 irrigation systems will be needed. They will be used over the five years of restoring 60 acres, about the expected life of the systems. Cottonwood, and understory shrubs, will be planted in groups of five, each serviced by a 2 gallon per hour emitter. Each tank will need to be filled once per week for eight weeks (during July and August dry season). A local fire fighter tanker truck and operator will be retained for 1 day/week over 8 weeks

Costs for this objective are expected to be $\$ 3500$ per acre. This reflects tillage, herbicide, irrigation, plant collection, greenhouse growth, etc. I believe this is a minimum cost. Carothers et al. (1990) summarized 17 riparian restoration attempts in 
the western U.S. Of the 17.13 were primarily cottonwood dominated. The average cost oer acre for these 13 was $\$ 4289$, with a range from $\$ 1380$ to $\$ 40.000$ /acre. The estimate of $\$ 3500$ is $18 \%$ less than the above mean, not counting for inflation.

\section{Objective III.3. Upland Forest Buffer}

About 76 acres of mixed coniferous-deciduous forest exists in the southeast quadrant. along the highway. Besides providing habitat to forest wildlife, it also acts as a sight and sound barrier. About $1 / 2$ mile of project area along the highway to the north is without this forest buffer. We propose to plant about 11 acres of mixed forest as both habitat and buffer. Bare root Douglas fir, lodgepole pine and western larch will be underplanted. Containerized aspen and red-osier dogwood will be planted towards the slough as an associated deciduous band adjacent to the coniferous buffer.

\section{Objective III.3.1. Pasture Management}

In order to assist mitigation for Canada goose habitat units, high quality brood habitat needs to be created. Brood habitat may well be more restrictive to populations than nesting sites. as evidenced by long travel distances to brood areas following hatching (Ball et. al., 1981). Mackey et. al., (1987) found that grazing broods generally remained within 30 meters of the security of water. Management of brood pasture will entail keeping grass lengths at 4" or less, during the brood season (April-July 15). Pastures should be managed out to $100 \mathrm{~m}$ from the water edge to provide visual security. Based on the above parameters, and planned wetland expansion, there is an estimated 80 acres of brood pasture that could be created.

This will be done over a 4 year period, involving 20 acres/year. In year one the area will be grazed hard by cattle and/or sprayed with Roundup herbicide to weaken/remove competition. A fall tillage and planting to winter wheat will occur. This will be allowed to mature and left over one winter as wildlife food. In the following spring the area will be disced and seeded to native foxtail grasses (Alopecurus spp.) which are water tolerant. In addition a top seeding of Camas (Camassia quamash) will occur. Once very common, and a preferred cultural and food item of the tribe, it is now much reduced over its range. Improper livestock grazing quickly removes it from the flora. It is still common on the reservation where livestock grazing is less intense. Seed will be collected here for use on project, and for propogation research at EWU. 
Following wild casture establishment, annual mowing or haying will occur tollowing seea set by camas. Pisroose is to prevent invasion by undesired species maıntain vigor of grasses ana open nature desired by flightless broods of Canada geese.

In order to establish and maintain wild pastures for goose food sources, equipment will be neeaea. This equipment will also be used to maintain and enhance wetlanas. roads and aikes. and to cultivate plantings for maximum survival. Weed competition and other moisture loss factors are a major reason for restoration failure (Baird 1989). This will allow maximum flexibility in management by the project manager in most all deveiooment objectives. Costs for a medium-sized tractor, haying equipment and a disc and grain arill is expected to be $\$ 80.000$. This is listed as a lump sum payment in year 3. incluaing a cash payment discount of $10 \%$ (L., Adams pers. comm.).

\section{Level IV}

Long term analysis of results, and assurance of benefits is essential, yet often ignored or improperly funded in mitigation projects. Kusler and Kentula (1990) in their data base noted that monitoring of mitigation projects has been uncommon so that the potential information gained to Improve future projects is not being accrued.

\section{Objective IV.1. Monitoring and Evaluation}

The Power Council. Bonneville. Columbia Basin Fish and Wildlife Authority and the Kalispei Tribe need to monitor and evaluate the effectiveness of the wildlife program. Assessment of conditions before and after habitat enhancement is essential for auditing purposes.

Reference data concerning changes relative to the baseline condition (Objective 1.1.) will be continued throughout the life of the project. In addition, habitat and vegetation responses will be measured and correlated with trends in wildlife populations. Permanent plots in eacn habitat type will be established and measured over time.

Habitat will be monitored by selecting and permanently marking each HEP site in each of the vegetation types in the study area. This has been done. Parameters to be measured include HEP variables by target species as well as species of trees, shrubs, 
forbs and grasses present, heignt. density and distribution of these species, percent tree and and shrub canopy cover. acres of wetlands and riparian forest successfully established. Water table levels will be monitored and correlation with vegetation development. At year 10. a HEP wiil be conducted using the target species.

Wildlife populations will be assessed by conducting a winter survey to estimate the number of bald eagles and deer. spring pair counts to determine the number of waterfowl, line transect song bird estimates, and other standard methods for estimating animal populations. The results of these efforts wiil then be correlated with the follow-up HEP.

Annual photographic documentation will occur at each HEP site and at each planting site to record vegetation development.

The migitation project offers a unique opportunity to rectify current deficiencies in method knowledge. In the creation of a wetlands restoration data base, Ischinger and Schneller-McDonald (1988) looked at study length duration. Based on 79 records, they found the majority of records concerned with one year, or less, of monitoring and evaluation efforts. Few studies were sufficient to provide useful knowledge as to long term relationships and success.

\section{Objective IV.2. Operations and Maintenance}

The category, like monitoring and evaluation, seemed mostly ingnored in the literature. The only way to assure long term success is to apply them both for a term equal to the life of the hydro project to which they are assigned. Adaptive management cannot occur unless both are applied.

Funding for a half-time manager and half time biologist, plus equipment costs and overhead has been included in Section 5.2 BUDGET.

\subsection{BUDGET}

Project costs were figured using a variety of methods. An extensive literature review, many telephone conversations to resource personnel, equipment and nursery estimates, and personnel costs at UCUT, KTOI and EWU and local operators were all 
usea. Costs are in 1992 dollars. Inflation was not figured within. Discussion of project costs by objective/task. and a funding mechanism follows.

\subsubsection{Project Costs}

Objective 1.1. Baseline Inventory

One "full-time equivalent" (FTE) personnel is needed throughout the project. This will consist of a half-time manager, and a half-time biologist. Together they will be responsible for supervising, coordinating, implementing, monitoring and maintaining the project.

$\begin{array}{llll}1 \quad \text { FTE } & \$ & \$ 30.000 & \$ 30,000 \\ \text { Overnead } & \$ & 35 \% & 10,500 \\ \text { Benefits } & @ \quad 35 \% & 10,500 \\ \text { Mileage, } & \text { equipment, supplies } & 20,000 \\ r \\ r\end{array}$

Objective $1.2 \quad$ Shoreline Bank Repair

Wooay Plantings $\quad 3,000$

Conifer Mulch 2,000

Breakwater @ $\$ 10 / \mathrm{ft} \times 1500 \mathrm{ft}$. 15,000

Objective $1.3 \quad$ Site Cleanup

Farm Site 20,000

Powerlines

Objective $1.4 \quad$ Hydrology

Surface Flows (included in Objective 111.1) -0-

Ground Water Wells (10 well points @ \$150/point) $\quad 1,500$

Tensiometers (3@ each well point at \$100/ea) 3,000

Objective $1.5 \quad$ Weed Control

Initial Control 4,500

Annual Maintenance 250 
Objective II.1. increased Perch Tree Size

Silviculture (BIA assisted)

Objective II.2. Increased Deciduous Tree Density

Aspen (included in Objective II. 1)

-0 -

Cottonwood Enhancement

(100 stems/acre $\times$ \$4/stem $\times 20$ acres) $\quad 8,000$

Objective II.3. Nesting Islands

Islands ( 7 at $\$ 5.020 /$ ea)

35,140

Objective II.4. Shoreline Revegetation

Woody Plantings

(100 stems @ \$4/stem on 10 acres) $\quad 4,000$

Bulrush Plantings

(one "clump" $/ 300$ ' shore 1

$\$ 100 /$ clump $\times 12,760 \mathrm{ft}$. shore) $\quad 4,300$

Objective II.5. Restoration of Shrub Swamp

Wetland Shrub Planting (\$3,500/acre x 10 acres) $\quad 35,000$

Objective III.1. Wetland Restoration

Control Structures $\quad 38,670$

Objective 111.2. Riparian Forest Restoration

60 acres @ 3,500/acre 210,000

Objective III.3. Upland Forest Buffer

11 acres @ \$520/acre 5,720

Objective III.4. Pasture Management

Includes tractor, disc, drill, auger $\quad 80,000$

Objective IV.1. Monitoring \& Evaluation

(as Objective Baseline) $\quad 71,000$ 
Objective IV.2.

Includea in Objective IV.I.
Operations and Maintenance

$-0-$

\subsubsection{Total Amount to Implement}

Total costs for implementation, $M \& E$ and 0 \& $M$ through year ten is illustrated in Table 4.

Table 4. Objective and cost by year of project.

\begin{tabular}{|c|c|c|c|c|c|c|c|c|c|c|c|}
\hline \multicolumn{12}{|c|}{ jost by Year } \\
\hline Objective & 1 & 2 & 3 & 4 & 5 & 6 & 7 & 8 & 9 & 10 & $11+$ \\
\hline : Basolne & 71000 & & & & & & & & & & \\
\hline i 2 Bank Reparr & & 5.000 & 15.000 & & & & & & & & \\
\hline I 3 Site Cleanup & 20.000 & & & & & & & & & & \\
\hline 14 Hydrology & & 4.500 & & & & & & & & & \\
\hline i 5 Weed Control & 2.000 & 1.000 & 500 & 500 & 500 & 250 & 250 & 250 & 250 & 250 & 250 \\
\hline II 1 Perchtree & & & 7.600 & & & & & & & & \\
\hline 112 Tree Density & & & & 8.000 & & & & & & & \\
\hline 3 Nesung islanas & & & 10.000 & 10000 & 10.000 & 5000 & & & & & \\
\hline II 4 Shoreline Veg. & & & 4.000 & 4.300 & & & & & & & \\
\hline I 5 Shrub Swamp & & & & & 35,000 & & & & & & \\
\hline :I : Wetana & & 36.670 & & & & & & & & & \\
\hline ill 2 Fidanan & & & & & 42.000 & 42.000 & 42.000 & 42.000 & 42.000 & 42.000 & \\
\hline '/l 3 Forest Buffer & & & 5.720 & & & & & & & & \\
\hline :! 4 Pasture & & & & 60.000 & & & & & & & \\
\hline$V 1 M \& E$ & & 71.000 & 71000 & $7: .000$ & 71.000 & 71.000 & 71,000 & 71.000 & 71,000 & 71,000 & 71,000 \\
\hline$V 2 O \& M^{2}$ & & & & & & & & & & & \\
\hline Annual Total & 93.000 & $120.17 \mathrm{C}$ & $11362 \mathrm{C}$ & $173.80 \mathrm{C}$ & 156.500 & 116.250 & 13.250 & 13.250 & $\mid 13.250$ & 113.250 & 71.250 \\
\hline
\end{tabular}

1 Inflation not included.

2Included with Objective IV. 1. M \& E 


\subsection{SOURCES}

\section{$6.1 \quad$ Literature}

Baird. K. 1989. High quality restoration of riparian ecosystems. Restoration and Management Notes 7(2) 60-64.

Ball. I.J.; Bowhay, EL. and Yocum, C.F. 1981. Ecology and management of the western Canada goose in Washington. Wash. Dept. Game Biol. Bull No. 17.

Brinson. M.M.; Swift, B.L.; Plantico, R.C.; and Barclay, J.S. 1981. Riparian ecosystems: Their ecology and status. USFWS. RFW/OBS-81/17. $155 \mathrm{pp}$.

Burger, G.V. and Webster, C.G. 1964. Instant nesting habitat. Chapter in Linduska, J.P. ed. Waterfowl Tomorrow USDI Fish and Wildlife Service, Washington D.C.

Canning, D.J. and Stevens, M. 1989. Wetlands of Washington: A Resource Characterization. Land and Wetland Resources Subcommittee, Environment 2010 Advisory Committee, Wash. Dept. Ecology, Olympia.

Carothers, S.W.; Mills, G.S. and Johnson, R.R. 1990. The creation and restoration of riparian habitat in southwestern arid and semi-arid regions. Pgs. 351-366 in Kusler, J.A. and Kentula, M.R. eds. Wetland Creation and Restoration: The Status of the Science. Island Press, Washington, D.C.

Castelle, A.J.; Conolly, C.; Emers, M., Metz, E.D; Meyer, S.; Witter, M.; Mauermann, S.; Bently, M.; Sheldon, D. and Dole, D. 1992. Wetland replacement ratios: defining equivalency. Adolfson and Associates, Inc., for Shorelands and Coastal Zone Management Program, Wash. Dept. Ecology, Olympia, Publ. No. 92-08.

Cordery-Colter, Flying Goose Ranch, Cusick, Washington Environmental Survey. Report from $\mathrm{CH}_{2} \mathrm{M}$ Hill to Bonneville Power Administration, Portland, OR. Dec. 1991. 17 pp. 
Hoag, J.C.; Young, G.L.: and Gibbs, J.L. undated. Planting techniques for vegetating rıparian areas from the Aberdeen Plant Materials Center. USDA-SCS, Aberdeen, ID.

Ischinger, L.S. and Schneller-McDonald, K. 1988. Wetland restoration and creation in the West: What do we really know? pp 29-42 in Mutz, K.M.; Cooper, D.L.; Scott, M.L. and Miller, L.K. tech. eds. Restoration, creation and management of wetland and riparian ecosystems in the American West. Society of Wetland Scientists, Denver, CO.

Knopf, F.L. 1988. Riparıan wildlife habitats: more, worth less and under invasion. pp. 20-22 in Mutz. K.M.: Cooper, D.L.; Scott, M.L. and Miller, L.K. tech. eds. Restoration. creation and management of wetland and ripanan ecosystems in the American West. Society of Wetland Scientiest. Denver, CO.

Kusler, J.A. and Kentula, M.E. (eds.). 1990. Wetland Creation and Restoration: The Status of the Science. Island Press, Washington, D.C.

Lea, R. and Frederick, D.J. Bottomland hardwood restoration in the southeast- a prespective. Journal of land and water conservation. Sept/Oct. 1992.

Mackey, D.L.; Gregory, S.K.; and Mathews, Jr. W.C. 1987. Impacts of water levels on breeding Canada geese and methods for mitigation and management in the southern Flathead Valley, Montana. Bonneville Power Project \#83-2. Portland, OR.

Martin. R.C.; Hensen, H.J. and Mueleman, G.A. 1988. Albeni Falls wildlife protection, mitigation and enhancement plan. BPA Project No. 87-43. Portland, OR.

Merker, C. and Scholz, A. 1990. Kalispel Tribe of Indians Wildlife mitigation and restoration for Albeni Falls Dam. Upper Col. United Tribes Fisheries Center, EWU, Cheney, Wa.

Richter, B. 1992. Hydrologic monitoring manual. The Nature Conservancy, Boulder, co. 
Schemnitz, S.D. ed. Wildlife Management Techniques Manual. The Wildlife Society, Wash.

Sedgewick, J.A. and Knopf, F.L. 1991. Prescribed grazing as a secondary impact in a western riparian floodplain. Journal of Range Manage. 44(4):369-373.

Sorby, S.L.; Larson, G. and Ceretto, P. 1992. Flying Goose Ranch Mitigation Project undesirable plant survey for the Bonneville Power Administration. Pend Orielle County Weed Control Board, Newport, WA. BPA contract \#DE-BI-7992BP75859.

Swenson, E.A. 1988. Progress in the understanding of how to reestablish native riparian plants in New Mexico. In Murtz, K.M.; Cooper, D.L.; Scott, M.L. and Miller, L.K. tech. eds. Restoration, creation and management of wetland and riparian ecosystems in the American West. Society of Wetland Scientist, Denver, co.

\subsection{Personal Communication}

Adams, K. Adams Tractor Company, Spokane, WA.

Thompson. T. Bureau of Land Management, Spokane, WA.

Fulmar, K. USFWS. Turnbull NWR, Cheney, WA.

Scott, M. USFWS, National Ecology Research Center, Ft. Collins, CO. 


\section{APPENDIX 7.1}

\section{Habitat Evaluation Procedure for the}

Pend Oreille Wetlands Wildlife

Mitigation Project-flying Goose Ranch

\section{BY}

Chris Merker and Ray Entz

UCUT Fish and Wildlife Research Center

Department of Biology

Eastern Washington University 


\begin{abstract}
The Habitat Evaluation Procedure (HEP) was used to determine baseline informatron on habitat suitability for the target species using Habitat Suitability Index ( HSI) Models. These HSI species models consisted of the bald eagle - wintering and breeding, black-capped chickadee. Canada goose, muskrat, and yellow warbler. A HEP team was put together with persons from several different agencies. The team consisted of the following persons and agencies: Ray Entz, Ron Peters, and Chris Merker of UCUT Fish and Wildlife Research Center: Peter Paquet. NPPC wildlife biologist; Kathleen Fulmer, USFWS; Patrick Buckley, Pend Oreille County PUD \#1 resource manager; and Annette Brewer, Kalispel Indian Tribe resource manager, Using an ocular measurement method the HSI was conducted as a group with the HSI values for each variable being the agreed upon team value. The HSI values were determined to be as follows: bald eagle breeding-0.68 in the deciduous forest cover type and 0.63 in the coniferous forest cover type. bald eagle wintering -0.6 in the deciduous forest cover type and 0.4 in the coniferous forest cover type, black-capped chickadee -0.47 in the deciduous forest cover type, Canada goose -0.5 in the riparian herbaceous cover type, muskrat 0.96 in the herbaceous wetlands cover type, yellow warbler -0.68 in the deciduous shrub/decifuous shrub wetland cover types, and mallard - 0.3 in pasture type. These values are based on a $0.0-1.0$ scale where 1.0 is the optimum value for habitat in a given cover type. These values were within expected ranges as current land use has degraded the habitat within the property borders.
\end{abstract}

\title{
INTRODUCTION
}

Habitat evaluation procedure (HEP) is used extensively in today's fish and wildlife biological sciences to determine habitat losses and/or benefits to the habitat after construction of a facility, or enhancement or restoration of habitat. HEP utilizes habitat suitability index $(\mathrm{HSI})$ models for target species found within certain cover types. An example of this would be the muskrat HSI model for the herbaceous wetland cover type.

In 1987, baseline HEP data was collected by the Albeni Falls work group on the Pend Oreille River Area. During this survey the Albeni Falls work group provided HEP data for eight target species representative of area cover types that were adversely effected by the construction of the Albeni Falls Dam. Baseline data collected by the Pend Oreille wetlands work group was accomplished using the same target species as 
usea by the Alben falls work group excluding the white-tailed deer model. It was decided that the habitat and cover types were adequately Included by the other HSI models.

The Pend Oreille work group consisted of seven members, each of which was picked for expertise in a certain area and/or personal or agency interest. The work group consisted of the following individuals and agencies: Ray Entz. UCUT biologist; Chris Merker, UCUT wildlife biologist: Ron Peters, UCUT biologist: Kathleen Fuimer, USFWS biologist: Peter Paquet. NPPC wildlife biologist: Pat Buckley, Pend Oreille County PUD\#I resource manager; and Annette Brewer, Kalispel Indian Tribe resource manager.

The goal of this project is to obtain baseline data to determine current levels of habitat suitability for the project property and to present a representation of the benefits of restoration on the current habitat.

\section{METHODS}

Habitat types were mapped from color photographs, then ground truthed. Type area was computed using a summargraphics sketchpad and program digitize.

The HSI models for the Canada goose, breeding bald eagle and the wintering bald eagle were modified from those used by the Albeni Falls work group. The blackcapped chickadee, yellow warbler and the muskrat HSI models were acquired from Bob Martin, IDFG wildlife biologist and head of the Albeni Falls work group. Models and field data forms can be found at the end of the report. The HSI models were modified to a histogram format for ease $\mathrm{rn}$ use during the ocular measurement method. These models were forwarded to work group members for review and comments. It was determined that the ocular measurement method is as accurate as actual direct measurements (P. Ashley, WDW, pers. comm).

Each target species were selected for its association with specific cover types. Each HSI model consists of several variables with each variable being split into several categories. Each category was assigned a value between 0.0 and 1 .O. The scores for each variable was then calculated using the HSI equation(s) for each model and given a final HSI score (Table 7.1.1). This final score is criteria for which habitat suitability is 
determınea. The habitat suitability is based upon a numerical range between 0.0 and 1.0 . where 1.0 is the optimal suitability value for a given cover type.

Table 7.1.1. Life requisite(s), life requisite equations, and HSI values for each species according to the HSI models.

\begin{tabular}{|c|c|c|c|}
\hline Target Species & Life requisite & Equation & HSI value \\
\hline Bald eagle-breedıng & -iSI value & {$\left[\left(V_{1}\right)^{2} \times V_{2}\right]^{1 / 3}$} & Lde requiste \\
\hline Bald eagle-wintering & HSI value & {$\left[\left(v_{1}\right)^{2} \times v_{2}\right]^{1 / 3}$} & Life requisite \\
\hline Blackcapped chickader & $\begin{array}{l}\text { Food } \\
\text { Reorooucion }\end{array}$ & $\begin{array}{c}\left(v_{1} \times v_{2}\right)^{1 / 2} \\
v_{3}\end{array}$ & Lowest Life requisite value \\
\hline Canaaa goose & -ISI value & {$\left[\left(N_{1}+V_{2}\right) V_{3}\right]^{1 / 2}$} & Life requisite \\
\hline Muskrat & $\begin{array}{l}\text { Cover } \\
\text { Food }\end{array}$ & $\begin{array}{l}\left(V_{1} \times V_{2}\right)^{1 / 2} \\
\left(V_{1} \times V_{3}\right)^{1 / 2}\end{array}$ & Lowest Life requisite value \\
\hline Yellow warbierReproduction & $\left(V_{1} \times V_{2} \times V_{3}\right)^{1 / 2}$ & Reproduction & \\
\hline Mallard & Reproduction & $v_{1}$ or $v_{2}$ or $v_{3}$ & Lowest Life requisite value \\
\hline
\end{tabular}

\section{RESULTS}

Table 7.1.2. is habitat types classification and acreage used to figure Habitat Units by target species.

Table 7.1.3. summarizes the results of HEP including scores by species and habitat, and total Habitat Units of the ranch in its current condition. 
Table 7.1.2. POW Mitigation Project Flying Goose Ranch habitat types \& acreage, and dike length.

Habitat Type (parcel acreage)

Acres

Project (Boundary) Area

(incl. beacn \& slougns below $2041 \mathrm{msl}$ )

$487.4^{\prime}$

2. Riparian Forest $(22.75+0.5+0.2=)$

3. Open Water (Interior slough) $(5.2+1.9+1.0+0.9=)$

4. Herbaceous Emergent Wetland

5. Sedge Wetlana $(2.8+21.6+0.9=)$

6. Shrub Sedge Wetland $(1.6+0.7)$

7. Mixed Deciduous Coniferous $(5.1+77.9)$

8. Farm Building area

9. Deciduous Tree/Shrub Scrub

10. Beach and Slougn (outside dike)

11. Agriculture and open (by default: sum all above, subtract from Project-Area 487.4 - 203.4)=

12. Dike length (total)

*Does not equal 440 acres aut to Inclusion of land below high water mark outside the dike along river. 
Table 7.1.3. Habitat Suitability Index (HSI) scores habitat acres and Habitat Units (HU) for each of the target species at Flying Goose

Ranch.

\begin{tabular}{|c|c|c|c|c|c|c|}
\hline $\begin{array}{l}\text { Target Soecies/Habrat } \\
\text { Type }\end{array}$ & Vanaole & $\begin{array}{l}\text { Variable } \\
\text { Score }\end{array}$ & $\begin{array}{l}\text { Lffe req. } \\
\text { Score }\end{array}$ & $\begin{array}{c}\text { HSI } \\
\text { Score }\end{array}$ & $\begin{array}{c}\text { Habrtat } \\
\text { Acres }\end{array}$ & HUs \\
\hline $\begin{array}{l}\text { Sald eagie-breeding } \\
\text { deciduous forest cover } \\
\text { type }\end{array}$ & $\begin{array}{l}\text { V4-food } \\
\text { V2-nesvoercn } \\
\text { V3-dist. to water } \\
\text { V4-human aisturt. }\end{array}$ & $\begin{array}{l}V 1=0.8 \\
V \overline{3}=0.6 \\
V 4=0.4\end{array}$ & HSI Value & 0.63 & 23.5 & 14.8 \\
\hline $\begin{array}{l}\text { Bald eagle-breeamg } \\
\text { coniterous forest cover } \\
\text { type }\end{array}$ & $\begin{array}{l}V \text { i-food } \\
V 2 \text {-nesvoerch } \\
V 3 \text {-dist. to water } \\
\text { V4-human disturt. }\end{array}$ & $\begin{array}{l}V 1=0.8 \\
V 2=0.4 \\
V 3=0.9 \\
V 4=0.9\end{array}$ & HSI Value & 0.63 & 83.0 & 52.3 \\
\hline $\begin{array}{l}\text { Bald eagle-wtntenng } \\
\text { deciduous forest cover } \\
\text { ype }\end{array}$ & $\begin{array}{l}\text { VI-t ow } \\
\text { V2-Dercn } \\
\text { V3-dist. to water } \\
\text { V4-human aisturo. }\end{array}$ & $\begin{array}{l}V_{1}=1.0 \\
V_{2}=0.6 \\
V 3=1.0 \\
V_{4}=0.9\end{array}$ & HSI value & 0.84 & 23.5 & 19.7 \\
\hline $\begin{array}{l}\text { Bald eagle-wtntenng } \\
\text { confferous forest cover } \\
\text { type }\end{array}$ & $\begin{array}{l}\text { V1-food } \\
\text { V2-percn } \\
\text { V3-dist. to water } \\
\text { V4-human disturt. }\end{array}$ & $\begin{array}{l}V_{1}=1.0 \\
V_{2}=0.4 \\
V_{3}=0.9 \\
V_{4}=0.9\end{array}$ & HSI value & 0.74 & 83.0 & 61.4 \\
\hline $\begin{array}{l}\text { Black-capped chickadee } \\
\text { deciduous forest cover } \\
\text { type }\end{array}$ & $\begin{array}{l}\text { VI-\% tree closure } \\
\text { V2-avg. tree height } \\
\text { V3-No. snags/acre }\end{array}$ & $\begin{array}{l}V_{1}=0.25 \\
V 2=0.88 \\
V 3=0.87\end{array}$ & food $=0.47$ & 0.47 & $\begin{array}{c}23.5+ \\
8.6\end{array}$ & 15.1 \\
\hline $\begin{array}{l}\text { Canada goosel } \\
\text { herbaceous veg } \\
\text { (incl. open water slougn, } \\
\text { sedge, emergent, beach } \\
\text { types) }\end{array}$ & $\begin{array}{l}\text { V1-Island nest } \\
\text { V2-shoreline nest } \\
\text { V3-brood-reanng }\end{array}$ & $\begin{array}{l}V 1=0.3 \\
V 2=0.2 \\
V 3=0.5\end{array}$ & HSI value & 0.5 & $\begin{array}{l}9.0+ \\
29.0+ \\
25.3+ \\
20.1\end{array}$ & 41.7 \\
\hline $\begin{array}{l}\text { Muskray } \\
\text { herbaceous emergent } \\
\text { veg. inci. open water } \\
\text { slough, seage. emergent } \\
\text { types; }\end{array}$ & $\begin{array}{l}\text { V } 1 . \% \text { cover } \\
\text { V2-\% year/water } \\
\text { V3.\%orefer. veg. }\end{array}$ & $\begin{array}{l}V 1=0.93 \\
V 2=1.0 \\
V 3=1.0\end{array}$ & $\begin{array}{l}\text { cover }=0.96 \\
\text { tood }=1.0\end{array}$ & 0.96 & $\begin{array}{c}9.0+ \\
29.0+ \\
25.3\end{array}$ & 60.8 \\
\hline $\begin{array}{l}\text { Yellow warbler } \\
\text { deciduous snrub } \\
\text { deciduous shrub wetland } \\
\end{array}$ & $\begin{array}{l}V_{1-\%} \text { shrub cover } \\
\text { V2-avg. neight } \\
\text { V3-\% wetland shr. }\end{array}$ & $\begin{array}{l}V_{1}=0.9 \\
V_{2}=1.0 \\
V_{3}=0.5\end{array}$ & Reproduction & 0.68 & 2.3 & 1.6 \\
\hline $\begin{array}{l}\text { Mallard/ } \\
\text { open water wetland } \\
\text { pasture }\end{array}$ & $\begin{array}{l}\text { V1-wetland type } \\
\text { V2-nesting cover } \\
\text { V3-shoreline cover }\end{array}$ & $\begin{array}{l}V_{1}=0.5 \\
V_{2}=0.3 \\
V_{3}=0.7\end{array}$ & Reproduction & 0.3 & 256.6 & 77.0 \\
\hline
\end{tabular}




\section{DISCUSSION}

Accoraing to the HSI models and their values. the property currently has a fair value to wildlife. The major contrigbutor to the current conditions of the property is effects of cattle grazing. This is evident in that there is no visible leaves on any of the trees or shrubs below SIX feet. fences were not maintained allowing access to the river and wetlands, lack of plant recruitment. and erosion problems due to the extensive cattle travel in sensitive areas. The cattle damage was so extensive in certain areas that it skewed the results of the Canada goose HSI value at 0.2, and the black-capped chickadee V. at 0.25 . Grazing aenuaed river shoreline nest habitat, and weakened and killed riparran trees.

Bald eagle scores in ail 4 categories were lowest in the perch variable. This was due to 2 reasons: hrgh graae logging that removed largest trees in the coniferous forest type, and grazing that weakened and killed large cottonwoods in the deciduous riparian forest type. However. food resources and distance to water for all very good for eagles, attesting to the potential for increased eagle use. We commonly noted both young and adult eagles together using the ranch in late summer. We assumed they were a family group from the known nest immediately downriver on U.S. Forest Service land.

Converseiy, the muskrat scores indicate the existing high quality of the wetland slough. The permanency of the water supply (V2) and the mix of preferred vegetation species (V3) are idea!. The \% cover score (V1) while high at 0.93 . could be slightly Improved to a 1.0 by opening the dense emergent stands.

The HEP (HSI) scores can be very useful in designing a management plan. First efforts should be targeted at variables with lower scores. We suggest that all variables with scores of 0.6 or lower be targeted for initial improvement efforts. Using this criteria the following variables would be selected:

${ }^{*}$ Increased perch tree size in both forest types

*Increased tree density in deciduous forest

- Construction of nesting Islands

- Revegetation of river shoreline

${ }^{*}$ Restoration of wetland shrubs

${ }^{*}$ Increased grass nesting cover

*Increase in seasonally flooded wetland type 
In this way, for a given cost of inputs, maximum benefits would result by rarsing the scores of the weakest varrables.

Following the target efforts above, additional HUs could be captured by converting the open pasture ground to other more desirable habitat types. In our models, Canada goose brood habitat (V3) and mallard nest habitat (V2) is represented in the pasture. Score for this variable is only moderate due to much of the interior of the pasture field being too far from water. or very low in cover quality. Therefore, restoring deciduous riparian forest to 160 acres of the interior portion of the pasture for example, would greatly increase bald eagle, black-capped chickadee and yellow warbler HUs, without decreasing Canada goose HUs. Goose HUs could be increased by development of additionai wetlands within the pasture, increasing brood security by increasing water-pasture edge, and also try maintaining some Improved pasture. Mallard Hus could be increased by simply allowing grass to mature undisturbed and retained over winter for spring nesting cover. 


\section{References}

Allen, A. W. • 984. Habıtat surtability models: muskrat. FWS/OBS-82/10.46 Western Energy Land Use Team. U.S. Fish and Wildlife Service. Fort Collins, CO. 27pp.

Ashley, P. : 991. Personnel communication. Wildlife biologist. Washington Dept. of Wildlife. Sookane. WA.

Martın. R.C.. H.J. Hansen, G.A. Meuleman. 1988. Albeni Falls wildlife protection, mitigation. and enhancement plan. 123 pp. Bonneville Power Administration, Division of Fish and Wildlife: project no. 87-43.

Merker. C. and A. Schotz. 1990. Kalispel Tribe of Indians Wildlife mitigation and restoration for Albenı Falls dam: advanced design report and management plan. Upper Columbia United Tribes Fisheries and Wildlife Research Center. Eastern Washington University, Cheney. Technical report No. 5.

Schroeder, R.L. 1982. Habitat suitability models: yellow warbler. FWS/OBS-82/10.27 Western Energy Land Use Team, U.S. Fish and Wildlife Service. Fort Collins, co. $12 \mathrm{pp}$. 


\title{
HABITAT EVALUATION PROCEDURES BRIEFING PAMPHLET
}

\author{
PEND OREILLE WETLANDS \\ ALBENI FALLS DAM WILDLIFE MITIGATION \\ Sept. 23.1991
}

\section{PROJECT SCOPE}

Conduct a baseiine analysis of wildlife habitat values using the Habitat Evaluation ProcedurescHEP).

\section{OBJECTTVES}

The objective is to rate the quaiity of the habitat for lands being considered for acquisition or management as mitigation for losses to wildlife due to damages caused by construction of Albeni Falls Dam.

\section{PROCEDURES}

1.) An interdiscipiinary evaiuanon team will be assembled to conduct a site survey and coilect data on habitat type, quantity. quality. and wtldlife use under existing conditions.

2.) A "habitat suitability model" for each indicator species and a composite model will be provided. Each model will provide information and descriptions of key "life requisites" and graphs illustrating the relationships between these requisites(variables) and habitat quality.

3.) Based on this information. personal knowledge, professional judgment. and group discussion each member will rate the habitat as it relates to the given variables.

3.) Team members will discuss their ratings for the habitat variables. If they are widely different then the team member should discuss his/her rational for that decision.

5.) The teams rating for each variable shall be the consensus of all team members. If no consensus can be agreed upon the value u-ill be deferred to the team expen or a simple average of the teams values will be used. 


\section{Bald Eagle HSI Model (wintering and breeding)}

$V$, Bald eagie ib and w. Food reculrements -

Good. Abundant prey base Iunguiate carrion. fish of severai species. Wateriowi. and small nammas) avaiable throughout the year within :hree miles of potenaai nest/percn site. SI vaiue $=$ $\therefore 0$.

Moderate. Moderate prey availability within three miles of potentiai nesvperch site. Water somermes frozen over early in the nesung penod. but some unguiate carrion avaiiable during that time. Alternatuve food sources may be within five miles of the nest or perch. SI value $=0.8$.

Fair. Minimal prey base within five miles of poiential nesvperch site. Water rrozen over late into rhe nesting cycle without aitemsuve food sources. SI value $=0.3$.

Poor. Insufficient prey base to sustain eagles. SI value $\mathbf{= 0 . 0}$.
V2 Bald eagle (b and $w$ ) Vesuperch structure: ive $r \mathrm{rm}$. and density -

Best. Old growth spruce. Dougias fir. or ponderosa pine in coniferous areas: old growth cottonwood in deciduous stands: stands dense and continuous and exceeding 10 acres in size. SI value $=\mathrm{i} .0$.

Good. Scattered old growth trees in stands of moderate (mature) aged trees as above exceeding 10 acres in size. SI value $=0.9$.

Fair. Scattered old growth trees. as above. in open areas ( without screening from younger aged trees). SI value $=0.6$

Poor. Dominant trees available are old growth lodgepoie pine in coniferous areas or aspen in deciduous stands. SI value $=0.4$.

Minimal. Potential nest or perch structures are shrubs or young trees, no screening present. SI value $=0.0$. $\checkmark 3$ Bald eagle (b). Distance to water bodv with sufficient orevavailability -
A. $\leq 1$ kilometer. SI value $=1$. O.
B. 2 kilometers. SI value $\mathbf{= 0 . 9}$.
C. : kilometers. SI value $=0.6$.
D. 4 kilometers. SI value $=0.2$.
E. $\geq 3.5$ kilometers. SI value $=0.0$.

\section{Cover types}

Riparian deciduous forest

Coniferous forest

\section{Bald eagle (b). Human activity level -}

Good. Natural vegetation dominates area; no permanent developments or human structures: no human activity within the area during the nesting period. SI value $=1$.O.

Moderate. Area of farming g-round or pasture surrounds site; occasional use of area by predictable humans, such as a farmer or stockman; human activity occurs late in the eagle nesting cycle. SI value $=0.9$.

Fair. Dispersed recreation campsites or trails, or occasionally used boat docks within vicinity of potential nest or perch site: activity occurs during brooding period only. SI value $=0.4$.

Poor. Developed sites, e.g. campgrounds, boat launches. etc.. within vicinity of potential nest or perch site; heavy human use of area during incubation period. SI value $=0.0$. 


\section{Equation -}

Wintenng - Food $=V$. and Perch $=V$. The HSI value is equal to the lower of the two variables.

Breeding - Food $=\vee !$ and NesuPercn sites $=\vee 2$. The HSI value for breeding bald eagles is calculated as follows: $[(V .): \times \vee]^{: 3}$

\section{Bald ezgie overnew -}

The model recognizes that proximity to prey base. quality of prey base, and quaiity of nesting and perching habitat. and amount of human disturbances are the most important components determining the quality of breeding and wintering bald eagle habitat.

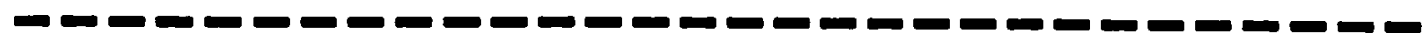

This HSI model was taken from the Albeni Falls Wildlife Protection, Mitigation and Enhancement Plan (.Martin et. al 1987). 
Black Capped-Chickadee HSI Model


Black capped-chickadee variable definitions -

V 1 - Black capped-chickadee. Percent tree canop! $\therefore$ osure is the percent of canopy closed by vertical rrojection of the canopy in the cover type.

12 - Black capped-chickadee. The average height of .) verstory trees is the averge height from the ground of :he overstory trees present in the cover type.

$\vee 3$ - Black capped-chickadee. Sumber or' snags 10 - 2: $\mathrm{im} / 0.4$ ha. is the number of snags usabl e by bl ack capped-chickadee's in the cover type.

Equation -

Life reauisire Cover tvpe

Food Deciduous forest iv. $x$ V.): :

Deciduous forested wetlands

Reproduction Deciduous forest

Deciduous forested wetlands

The HSI value for the black capped-chickadee is equal to the lowest life requisite value. 


\section{Black-capped chickadee overview-}

This model considers the ability of the habitat to meet the food and reproductive needs of the black zapped-chickadee as an indication of the overall habitat suitability. Cover needs are assumed to be met by the food and reproductive requisites and water is assumed not to be limiting. The food component assess vegetation conditions and the reproduction component assess the abundance of suitable snags.

This HSI model was modified into a histogram from the HSI models: black-capped chickadee, FWS/OBS-82/10.37 by R. L. Schroeder, 1983. 


\section{Canada Goose HSI Model}

$\because$ anada goose : and nesnra nazibar -

Good. Stable isiands present: reiauveiy high horeline:area ratio: ground cover on pomons of :siands 4 to i 6 incnes high: srood habitat within $i$ mile of area. SI vaiues between (). 8 and 1.0.

Fair. Siable isiands present: reiativeiv low shoreline/ares ratio: or cover on isiands $<4$ or $>\mathrm{i} 6$ :nches in heignt: or brood habitat within 1 to 2 :niles from area. SI vaiues detween 0.5 and 0.7 .

Poor. So stable isiands present: or isiands with irom area. SI vaiue between 0.0 and 0.3 . limited or no cover: cr brood habitat $\geq 2$ miies

V2 Carada goose. Shoreiine nesting habitat -

Good. Pomons of cover within 10 meters or water: ground cover 4 to 16 inches high; wetland iuffer within 50 meters of shoreiine. mav Include sloughs of open water: brood habitat within 1 mile. SI vaiue $=0.5$.

Fair. Portions of shoreline cover within 10 meters of water. ground cover 4 to 16 inches high; adjacent wetland buffer within 50 meters of shoreline Does not include open water wetlands); or brood habitat 1 to 2 miles away.

SI value between 0.3 and 0.4 .

Poor. So shoreline cover or shoreline cover taller ihan 16 inches and/or shorter than 4 inches: or wetland buffer $>50$ meters to absent: or brood habitat $>2$ miles away. SI vaiue between 0.0 and 0.2 .

Note: wetland buffer refers only to the proximity of the wetland to the shoreline nesting habitat.

\section{Equation -}

The HSI value is calculated 3s follows: $\left[\left(\mathrm{V}_{1}+\mathrm{V}_{i}\right) \mathrm{V}_{;}\right]^{: / 2}$

Good. Brood pasture essily accessible from main water body; foraging zones common: vegetation $<\downarrow$ inches tail: average $>\mathrm{i}$ acre in size: open water wetlands are present: within 1 miie of nesting habitat. SI value between 0.7 and 1.O.

Fair. Less than above and/or no open water wetlands; or area is 1 to 2 miles from nesting habitat. SI value between 0.4 and 0.6.

Poor. Little or no brooding are 3 : or area is $\geq 2$ miles from nesting habitat. SI vaiue between 0.0 and 0.3 .

\section{Canadian goose overiew -}

The model recognized that the quality of shoreline habitat. the presence of islands. and quality of brood-rearing habitat are the most important components determining the quality of Canada goose breeding habitat.

This HSI model was taken frum the Albeni Falls Wildlife Protection. Mitigation, and Enhancement Plan by Martin et. al, 1987. 


\section{Uuskrat HSI Model}

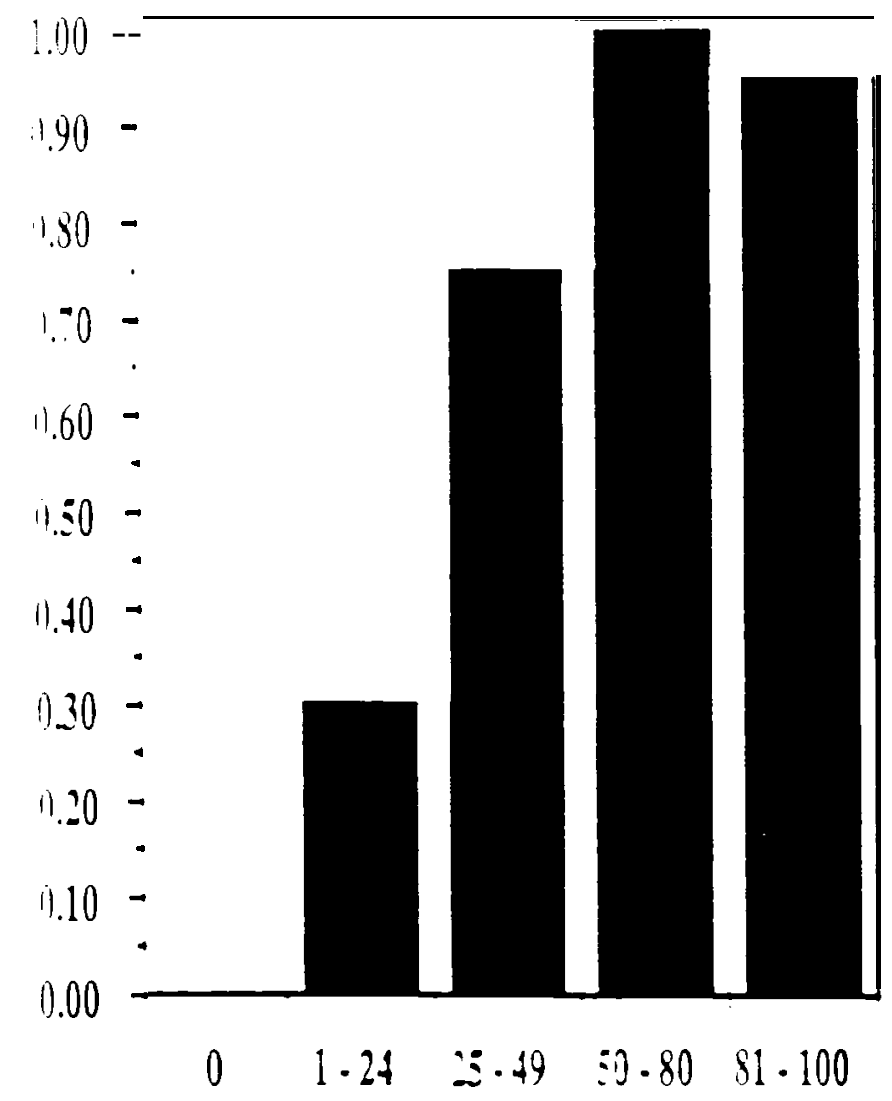

$\therefore \quad$ Percent canopy cover of emergent herbaceous regetation

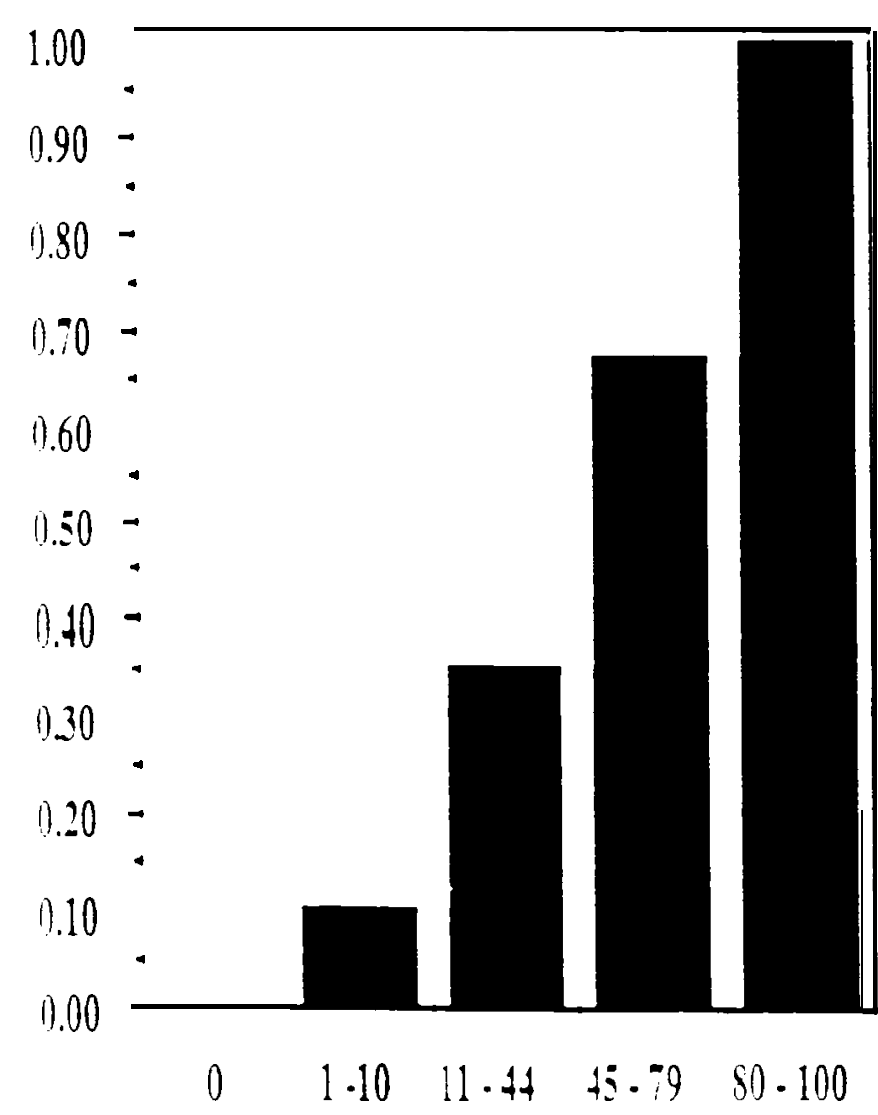

$v_{3}$ Percent of emergent herbaceous
1.00

$19.90-$

$1.80-$

$1.70-$

i). 60

$11.50-$

1). 40

1) 30

17.20 -

1).10

0.00

$\begin{array}{lllll}0.60 & 61.70 & 71.85 & 86.99 & 100\end{array}$

Percent of year with surface water present

lquskrat variable definitions -

V1 - Muskrat. Percent canopy cover of emergent Serbaceous vegetation is the percent of the water iuriace shaded by a verical projection of the anopies of all emersent herbsceous vegetation. 50th persistent and non-persistent.

12 - Muskrat. Percent of vear with suface water present is the proportion of the year in which the cover type has suriace water present.

V8 - Muskrat. Percent of emergent herbaceous vegetation consisting of Olney bulrush. common :hreesquare bulrush. or cattail considering both persistent and non-persistent types. 
Equanon -

Liferequisite Covera Equation

Cover Herbaceous itedand $\left.V . \times V_{:}\right)^{12}$

Food Herbaceous Wetland $\quad V \times V.)^{: / 2}$

The HSI vaiue for the muskrat is equai to the lowest life requisite value.

\section{Muskrat overview -}

Year-round habitat requtrements of the muskrat can be fulfilled within wetland habitats that provide herbaceous vegetanon and permanent surface water with minor fluctuations in water levels. Wetlands characterized by seasonai drying an absence of emergent vegetation, or both. have less potential as year-round muskrat habitat than wetlands with permanent water and an abundance of emergent vegeta:10n. It is assumed that food and cover are interdependent characteristics of the muskrat's habitat and that measures of vegetative abundance and water permanence within a wetland can be aggregated to reflect habitat conditions favoring maintenance of the muskrat's food and cover requirements. The reproductive habitat requirements of the species are assumed to be met when adequate v:ater, food, and cover conditions are present.

This HSI model was modified into a histogram from the HSI Models: muskrat, FWS/OBS-82/ 10.46 by A. W. Allen and R. D. Hoffman, 1984. 


\section{Yellow Warbler HSI Model}

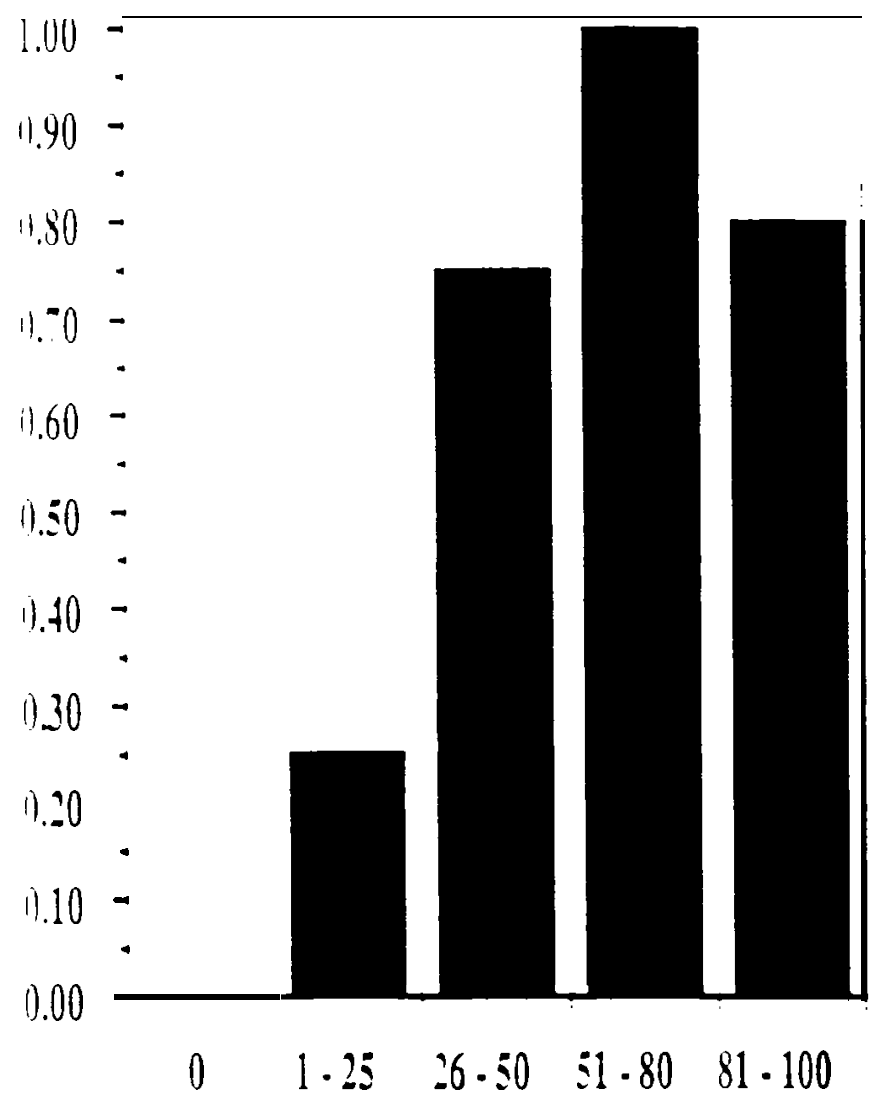

, 1 Percent deciduous shrub crown cover v2

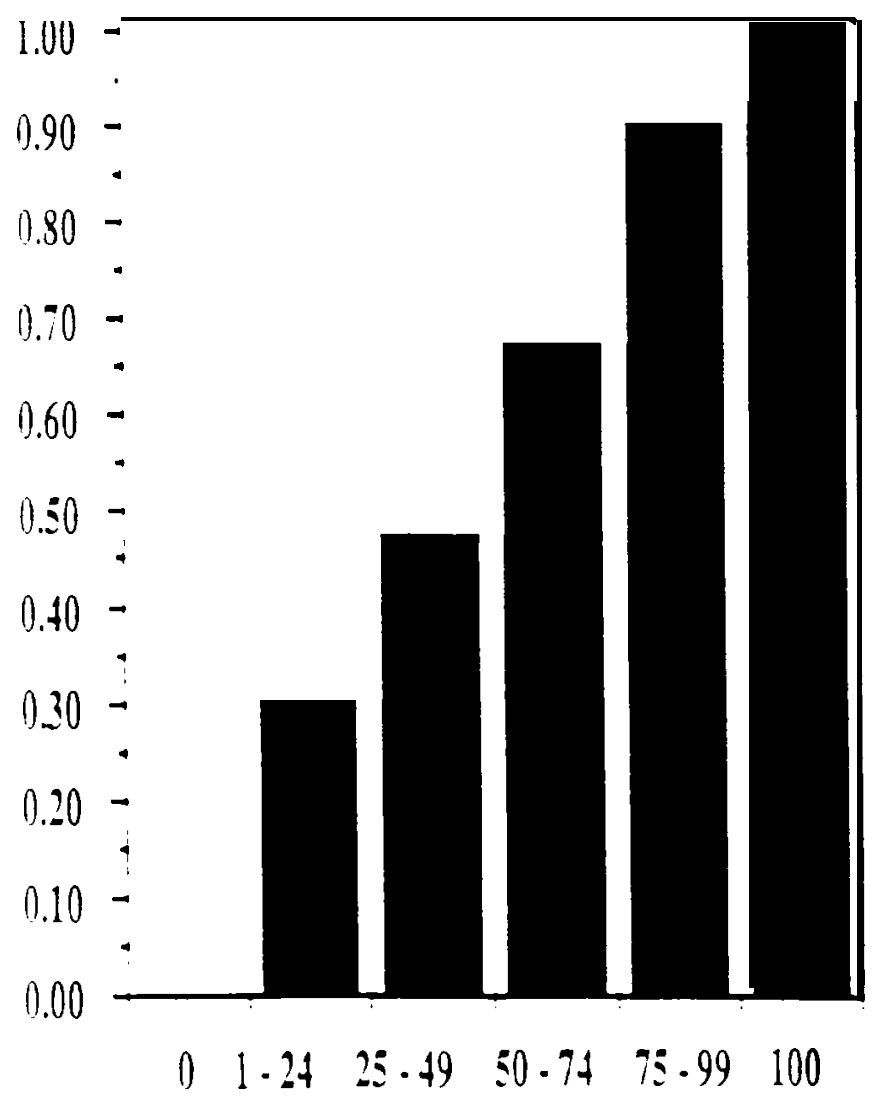

Yellow warbler variable definitions -

V1- Yellow warbler. Percent deciduous shrub srown cover is the percent of the ground shaded by a vertical projecton of the canodies of woods ¿eciduous vegetation that 15 iess than $5 \mathrm{~m}$ in height.

12 - Yellow warbler. Average height of deciduous shrub canopy is the average height from the ground to the top of those sirubs which comprise the uppermost shrub canopy.

V3 - Yellow warbler. Percent of deciduous shrub zanopy comprised of hydrophytic (i.e. wetiand species I shrubs is the relative percent of the umount of hydrophytic shrubs as compared to a.1 shrubs based on varizble? 


\section{Equavion}

\section{Life requisite Covernze Equation}

Reproduction Deciduos shrub $\quad$ V $\left.\times V_{:} \times V_{:}\right)^{: 2}$

Deciduous shrub wetland

The HSI vaiue for the yeilow warbler IS equal to the reproduction value.

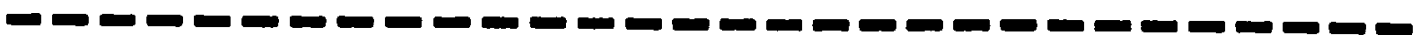

\section{Yellow warbler overnew -}

It is assumed that optimal habitats contain $100 \%$ hydrophytic deciduous shrubs and that habitats with no hydrophyric shrubs will provide marginal suitability. Shrub densities between 60 and $80 \%$ crown cover are assumed to be optimal. As shrub densities approach zero cover suitability also approaches zero. Totally closed shrub canopies are assumed to be of only moderare suitability, due to the probable restricrions on movement of the warblers in those conditions. Shrub heights of $\mathbf{2} \mathrm{m}$ or greater are assumed to be optimal. and suitability will decrease as the heights decrease.

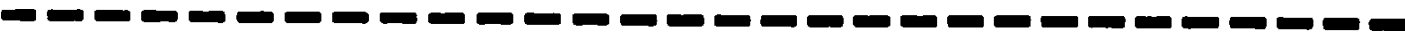

This HSI model was modified into a histogram from the HSI Models: yellow warbler, FWS/OBS8200.27 by R. L. Schroeder, 1982. 


\section{Habitat Sultability Index \\ Mallard (Anas platyrhyncos) \\ Breeding Season Only}

\section{Life Requisite Values}

Food (XI)--Related to the area of various wetland types within a sampling area that are shallow enough for a dabbling duck to feed $(<60 \mathrm{~cm}$ water depth is optimum) during the breeding season. Model assumes that seasonally flooded wetlands (i.e. wet meadows, etc.) provide a better food source than permanently flooded wetlands.

Reproduction (X2)--Related to the height and density of nesting cover (residual vegetation).

Cover (X3)--Related to the percent of shoreline dominated by emergent or scrub-shrub wetland vegetation. Shorelines with little or nor vegetation provide marginal escape cover for broods. Only wetlands with open water available during the brooding season should be evaluated.

\section{Habita_Evaluation_Criteria}

Food (XI): Seasonal wetlands, which produce highest quanitities of aquatic invertebrates, are preferred feeding habitat for laying mallard hens. The density of mallard pairs/hectare is assumed to be higher in seasonal rather than semipermanent wetlands.

A - Temporarily flooded: surface water is present for brief periods during growing season. $\mathrm{SI}$ value $=0.3$

B - Seasonally flooded: surface water is present for extended periods especially early in the growing season, but is absent by the end of the season in most years. SI value $=1 . \mathrm{O}$

C - Semipermanently flooded: surface water persists throughout the growing season during most years. SI value $=0.8$ 
D - Permanent flooced: water covers the land surface throughout the year in all years. Vegetation is composed of obligate hydrophytes. SI value $=0.5$

Reproduction (X2): Mallard nestıng success is the highest in cover with the greatest height-density of residual vegetation (i.e. concealed from all directions). Robel method was used as the visual obstructron technique (height and density). Reproduction value (X2) is a function of the height and density of nesting cover (residual vegetation).

Shoreline Cover (X3): Mallard broods will utilize wetlands having sparse to dense emergent of scrub-shrub vegetation. Wetlands devoid of wetland vegetation or open water are usually avoided. Marshes with shorelines bare of emergent vegetation are used less.

Measure the percent of shoreline dominated by emergent and/or scrub-shrub wetland vegetation for brood rearing wetlands ( $>2$ acres in size with some open water during brooding season):
A - $\quad 50 \%$ to $100 \%$ of shoreline. SI value $=0.7$ to 1.0
B - $\quad 15 \%$ to $50 \%$ of shoreline. SI value $=0.4$ to 0.6
C - $\quad 0 \%$ to $15 \%$ of shoreline. SI value $=0.1$ to 0.3

The habitat suitability index is the lowest $\mathrm{Xn}$ value. 


\section{Suggested Measurement Techniques}

Large sampling areas that are representative should be randomly selected. At least four sampling areas per area snould be used. Variables XI and X3 can be measured from aerial photography with field ground truthing. Variable $\mathrm{X} 2$ should be measured in the field in upland habitat types adjacent to wetlands. Specific suggestions on measurement techniques of each variable are provided below.

$\mathrm{XI}=$ Calculate area of varıous wetland types within each sampling area using a digitizer, or dot grid or planimeter. Multiply each wetland area by its SI for a weighted value. Sum the weighted values in the sampling area and divide by the total wetland acreage for a weighted sample area SI value.

$\mathrm{x} 2=$ Field measure height and density of residual vegetation using the visual obstruction technique (Robel pole used here). Sampling areas should be located on aerial photographs.

x3 $=$ Measure the amount of shoreline vegetation for each wetland type $>2$ acres in size and with some open water during brood-rearing season from aerial photographs. Calculate SI value for each wetland based on measurements. Multiple SI value times wetland area for a weighted value. A standard for lacustrine systems (i.e. littoral zone or 100 meters from shore) will need to be established as providing brood-rearing habitat. Sum weighted values in each sampling area and divide by total wetland acreage for a sample area SI value. Some field verification of shoreline vegetation should be conducted. 


\section{APPENDIX 7.2}

\section{Preliminary fisheries and water quality survey of Flying Goose Ranch}

On May 29. 1992 a preliminary fisheries and water quality survey was performed in the slougn on the proposed Pend Oreille Wetland Wildllife Mitigation site north of the Kalispel Indian Reservation. B. Ashe UCUT Fisheries Biologist, C. Merker, UCUT Wildlife Biologist and G. Nenema. Jr.. Kalispel Tribe Resource Technician conducted the survey.

A backpack electroshocker was used to sample the fisheries community along the edge of the slough. Both the east and west banks on the north end of the slough were sampled for approximately 200 feet. In approximately 20 minutes of shocking only 2 fish were captured. Both of these were pumpkinseed (Lepomis_gibbosus) 4.5 to 5 inches in length. Several other fish were sited but we were not able to capture them. We believe we saw one young-of-the-year bass, but it was not captured. No other young fish were sited from any species. At least one possible nest was sited in the shallow waters of the edge of the pond. It is suspected that it was a pumpkinseed nest, which is generally a shallow depression about a foot in diameter in a gravel, sand or mud bottom.

Water quality data was collected at one site on the slough (Table 1). Parameters were measured using a Hydrolab Scout II. These data were collected at the duck blind site on the east bank of the slough.

Dominent plant species in the slough included cattails (Typha spe) and Eurasion milfoil (Myriophyllum soicatum), both very abundant. Ceratophvllum and Elodea was also observed but in lesser amounts. The sediments were mucky and full of $\mathrm{H}_{2} \mathrm{~S}$ gas which was released in bubbles when stepped upon. There did appear to be a gravel bottom along the edge of the pond but it was not visible due to water turbidity. Water depth around the edge of the pond was approximately $1 \mathrm{~m}$ in most areas. The middle of the pond was deeper but measurements were not possible. Recent beaver activity has impounded water in several areas of the slough. The slough is physically blocked from Campbell Slough, and therefore the Pend Oreille River, due to a clogged culvert. If the culvert were unclogged emigration of fish from the slough would then be possible but 
Immigration would not. as the culven outlet was approximately 2 feet above water level of the receiving slougn.

Based on the data collected we believe the wetland slough has potential for rearing largemouth bass iry. Currently the macrophyte population is too abundant and the bottom of the pona is anoxic. If this wetland could be drained during the fall to reduce the macropnytes and dry out the bottom sediments it would greatly enhance fish habitat. Also it would be Deneficial to the fish if the water level of the pond was raised several feet to Increase available habitat and water quality.

Future surveys of this wetland to evaluate fisheries habitat should include zooplankton samples and benthic macroinvertebrates samples to determine natural food production for young fry. Also water quality stations whould be selected at several different locations arouna the wetland and should be monitored on at least a monthly basis. Samples collected should include fecal coliforms and heavy metal analysis. 
Table 7.2.

Water quality data from duck blind site on flying Goose slough.

\begin{tabular}{|l|c|c|}
\hline & Top of water column & Bottom of water column \\
\hline Depth & $0.1 \mathrm{~m}$ & $0.7 \mathrm{~m}$ \\
Temperature & $21.30^{\circ} \mathrm{C}$ & $19.92^{\circ} \mathrm{C}$ \\
Dissolved oxygen & $8.01 \mathrm{mg} / 1$ & $0.42 \mathrm{mg} /$ \\
Conductivity & $0.364 \mathrm{mmhos} / \mathrm{cm}$ & $0.369 \mathrm{mmhos} / \mathrm{cm}$ \\
pH & 7.23 & 6.79 \\
Oxidation reduction potential (ORP) & $0.207 \mathrm{volts}$ & $0.115 \mathrm{vohs}$ \\
Total dissolved solids (TDS) & $0.233 \mathrm{~g} / \mathrm{l}$ & $0.236 \mathrm{~g} / \mathrm{l}$ \\
\% saturation & $89 \%$ & $3.6 \%$ \\
\hline
\end{tabular}


Appendix 7.3.

Wetland engineering design for Flying Goose Ranch. 


\section{Constructron Soecrications}

\section{Nesting Islands}

Construction Sequence

Layout and stake edge of nesting island and outer edge of moat at desired location with the c-oper orientation

Determine elevations of existing ground level within nesting Island and moat

Begin excavating moat along outer edge with track-mounted excavator

Check bank slope and debth of excavatron to ensure at proper slope and grade

Haul excavated material from moat onto nesting island using a rubber tired front-end loader

Spread and compact nesting islana fill as work progresses

Check top of fill to ensure at proper elevation

Continue excavating moat and placing fill on island

Check nesting island bank slope and depth of excavation to ensure at proper slope and grade

Excavate drainage ditch between moat and water control structure

Check depth of excavation to ensure at proper elevation

Utilize excavated material as nesting island fill or as fill at another location within project area

\section{Equipment Specrifications}

Track Mounted Excavator -- Komatsu PC150 with bucket thumb or equivalent.

Rubber-Tirea Front-End Loader -- John Deere 624 with 3 - 4 yard bucket or equivalent.

$M Q$

\begin{tabular}{ll} 
Component & Quantity \\
\hline Excavation of Moat & $2600 \mathrm{cu}$ yds \\
Hauling and Placing Nesting Island Fill & $2600 \mathrm{cu}$ yds
\end{tabular}

ITE

Component

Layout and Construction Supervision

Site Excavation

Hauling and Placing of Nesting Island Fill
Time Required

$10 \mathrm{hrs}$

$26 \mathrm{hrs}$

$26 \mathrm{hrs}$

CE

Component

cost

Equipment

Excavator

Front-End Loader

26 hrs @ \$90.00/hr

$\$ 2,340.00$

26 hrs@ $\$ 80.00 / h r \quad 2,080.00$

Labor

Construction Supervision

10 hrs@\$60.00/hr

600.00

Total Cost per Island

$\$ 5,020.00$ 
Water Control Structure \#1

Construction Specrications

Construction Sequence

Identify location of new water control structure and outlet pipe

Excavate a trench 6 feet wide through dike for outlet pipe to elevation 2034.5

Remove existing pipe auring excavation of trench

Excavate around water control structure location to elevation 2033.5

Excavate inlet pond and trench to elevation 2035

Place 3/4-inch minus crushed rock in trench and area around water control structure and compact to depth of 6 inches

Assemble water control structure and install with bottom at elevation 2034

Assemble outlet pipe. attach to water control structure, and install at elevation 2035

Install backfill around outlet pipe in 12 inch lifts and compact

Install backfill around water control structure in 12 inch lifts and compact making sure structure does not distort

Final grading and shaping of backfill will blend into surrounding area

Revegetate all disturbed areas wtth natrve vegetation

Cut stop logs and wedges and install in water control structure

Equipment Specifications

Track Mounted Excavator -- Komatsu PC150 with bucket thumb or equivalent.

Rubber-Tired Front-End Loader -- John Deere 624 with 3-4 yard bucket or equivalent.

MQ

Component

Excavation of Trench and Water Control Structure Area

Excavation of Inlet Pond and Trench

Subgrade - 3/4-inch Minus Crushed Rock

Water Control Structure

Outlet Pipe

Pipe Couplers

Backfill Material (reuse excavated material)
Quantity

60 cuyds

$280 \mathrm{cu}$ yds

$8 \mathrm{cu}$ yds

1 ea

$32 \mathrm{ft}$

2 ea

$75 \mathrm{cu}$ yds 
ITE

Comoonent

Excavation of Trench and Water Control Structure Area

Excavation of Inlet Pona and Trench

Installation of Subgrade

Assemoly of Water Control Structure

Installation of Water Control Structure

Installation of Outlet Pipe

Installation and Compactton of Backfill

Construction Supervision
Time Required

$1.0 \mathrm{hrs}$

$3.0 \mathrm{hrs}$

$2.0 \mathrm{hrs}$

$12.0 \mathrm{hrs}$

$2.0 \mathrm{hrs}$

$2.0 \mathrm{hrs}$

$3.0 \mathrm{hrs}$

$10.0 \mathrm{hrs}$

CE

Component

Cost

Equipment

Excavator

Front-End Loader

10 hrs@\$90.00/hr

10 hrs@\$80.00/hr

$\$ 900.00$

800.00

Labor

Water Control Structure Assembly

Subgrade Installation

Water Control Structure Installation

Outlet Pipe Installation

Backfill Installation and Compaction

Construction Supervision

12 hrs@\$50.00/hr

2 hrs@\$50.00/hr

2 hrs@\$50.00/hr

2 hrs@\$50.00/hr

3 hrs@\$50.00/hr

10 hrs@\$60.00/hr

600.00

100.00

100.00

100.00

150.00

600.00

Materials

Water Control Structure

1 ea

$32 \mathrm{ft}$

Outlet Pipe

Pipe Couplers

2 ea

$8 \mathrm{cu}$ yds

Subgrade Material

stop Logs

12 ea

$1,985.00$

160.00

20.00

100.00

45.00

TOTAL COST $\$ 5,660.00$ 
Water Control Structure \#2

\section{Construction Soecrications}

\section{Construction Sequence}

Identify locatlon of new water control structure and outlet pipe

Excavate a trencn 6 feet wide through dike for outlet pipe to elevation 2037.5

Remove existing pipe auring excavation of trench

Excavate around water control structure location to elevation 2036.5

Excavate inlet pond and island drainage ditch to elevation 2038

Excavate outlet channel to elevation 2038 where needed

Place 3/4-inch minus crushed rock in trench and area around water control structure and compact to depth of 6 inches

Assemble water control structure and install with bottom at elevation 2037

Assemble outlet pipe. attach to water control structure. and install at elevation 2038

Install backfill arouna outlet pipe in 12 inch lifts and compact

Install backfill around water control structure in 12 inch lifts and compact making sure structure does not distort

Final grading and shaping of backfill will blend into surrounding area

Revegetate all disturbed areas with native vegetation

Cut stop logs and wedges and install in water control structure

\section{Equipment Specrications}

Track Mounted Excavator -- Komatsu PC1 50 with bucket thumb or equivalent.

Rubber-Tired Front-End Loader -- John Deere 624 with $3-4$ yard bucket or equivalent.

MQ

\begin{tabular}{lr} 
Component & Quantity \\
\cline { 2 - 2 } Excavation of Trench and Water Control Structure Area & $45 \mathrm{cu}$ yds \\
Excavation of Outlet Channel & $25 \mathrm{cu}$ yds \\
Excavation of Inlet Pond and Trench to Islands & $225 \mathrm{cu}$ yds \\
Subgrade $-3 / 4-$ inch Minus Crushed Rock & $8 \mathrm{cu}$ yds \\
Water Control Structure & $1 \mathrm{ea}$ \\
Outlet Pipe & $27 \mathrm{ft}$ \\
Pipe Couplers & $2 \mathrm{ea}$ \\
Backfill Material (reuse excavated material) & $45 \mathrm{cu}$ yds
\end{tabular}


ITE

Component

Time Required

Excavation of Trench and Water Control Structure Area

Excavation of Outlet Channel

Excavation of Inlet Pond and Trench to Islands

Installation of Subgrade

Assembly of Water Control Structure

Installation of Water Control Structure

Installation of Outlet Pipe

Installation and Compaction of Backfill

Construction Supervision

$1.0 \mathrm{hrs}$

$0.5 \mathrm{hrs}$

$2.5 \mathrm{hrs}$

$2.0 \mathrm{hrs}$

$12.0 \mathrm{hrs}$

$2.0 \mathrm{hrs}$

$2.0 \mathrm{hrs}$

$2.0 \mathrm{hrs}$

$9.0 \mathrm{hrs}$

CE

Component

Cost

Equipment

Excavator

Front-End Loader

9 hrs@\$90.00/hr

9 hrs@\$80.00/hr

12 hrs@\$50.00/hr

2 hrs@\$50.00/hr

2 hrs@\$50.00/hr

2 hrs@\$50.00/hr

2 hrs@\$50.00/hr

9 hrs@\$60.00/hr

Construction Supervision

Materials

Water Control Structure

Outlet Pipe

Pipe Couplers

Subgrade Material

stop Logs
1 ea

$27 \mathrm{ft}$

2 ea

8 cu yds

8 ea

TOTAL COST
S 810.00

720.00

600.00

100.00

190.00

100.00

100.00

540.00

$1,395.00$

135.00

20.00

100.00

30.00

$\$ 4,750.00$ 
Water Control Structure \#3

Construction Specrfications

Construction Sequence

Identify location of new water control structure and outlet pipe

Excavate a trench 6 feet wide through dike for outlet pipe to elevation 2037.5

Excavate around water control structure location to elevation 2036.5

Excavate inlet pond and island drainage ditch to elevation 2038

Excavate outlet channei to elevation 2038 where needed

Place 3/4-inch minus crushed rock in trench and area around water control structure and compact to depth of 6 inches

Assemble water control structure and install with bottom at elevation 2037

Assemble outlet pipe, attach to water control structure. and install at elevation 2038

Install backfill around outlet pipe in 12 inch lifts and compact

Install backfill around water control structure in 12 inch lifts and compact making sure structure does not distort

Final grading and shaping of backfill will blend into surrounding area

Revegetate all disturbed areas with native vegetation

Cut stop logs and wedges and install in water control structure

Equipment Specrfications

Track Mounted Excavator -- Komatsu PC150 with bucket thumb or equivalent.

Rubber-Tired Front-End Loader -- John Deere 624 with $3-4$ yard bucket or equivalent.

$\mathrm{MQ}$

Component

Excavation of Trench and Water Control Structure Area

Excavation of Outlet Channel

Excavation of Inlet Pond and Trench to Islands

Subgrade - 3/4-inch Minus Crushed Rock

Water Control Structure

Outlet Pipe

Pipe Couplers

Backfill Material (reuse excavated material)
Quantity

$\begin{aligned} & 95 \text { cu yds } \\ & 5 \text { cu yds } \\ & 400 \text { cu yds } \\ & 15 \text { cu yds } \\ & 1 \text { ea } \\ & 70 \mathrm{ft} \\ & 4 \text { ea } \\ & 95 \text { cu yds }\end{aligned}$


ITE

Component

Time Required

Excavation of Trench and Water Control Structure Area

2.0 hrs

Excavation of Outlet Channel

Excavation of inlet Pond and Trench to Islands

$0.5 \mathrm{hrs}$

Installation of Subgrade

Assembly of Water Control Structure

$4.0 \mathrm{hrs}$

Installation of Water Control Structure

$2.0 \mathrm{hrs}$

$12.0 \mathrm{hrs}$

Installation of Outlet Pipe

Installation and Compaction of Backfill

Construction Supervision

CE

Component

Cost

Equipment

Excavator

Front-End Loader

14 hrs@\$90.00/hr

14 hrs@\$80.00/hr

S $1,260.00$

$1,120.00$

Labor

Water Control Structure Assembly

Subgrade Installation

Water Control Structure Installation

Outlet Pipe Installation

Backfill Installation and Compaction

Construction Supervision

12 hrs@\$50.00/hr

2 hrs@\$50.00/hr

2 hrs@\$50.00/hr

4 hrs@\$50.00/hr

4 hrs@\$50.00/hr

14 hrs@\$60.00/hr

600.00

100.00

100.00

206.00

200.00

846.00

Materials

Water Control Structure

Outlet Pipe

1 ea

$70 \mathrm{ft}$

Pipe Couplers

Subgrade Material

stop Logs

4 ea

15 cu yds

8 ea

$1,395.00$

350.00

40.00

190.00

30.00

TOTAL COST $\$ 6,425.00$ 
Water Control Structure \#4

Construction Specrications

Construction Sequence

Identify location of new water control structure and outlet pipe

Excavate a trench 6 feet wide through dike for outlet pipe to elevation 2037.5

Excavate around water control structure location to elevation 2036.5

Excavate inlet pond to elevation 2038

Excavate outlet channel to elevation 2038 where needed

Place 3/4-incn minus crushed rock in trench and area around water control structure and compact to depth of 6 inches

Assemble water control structure and install with bottom at elevation 2037

Assemble outlet pipe, attach to water control structure, and install at elevation 2038

Install backfill around outlet pipe in 12 inch lifts and compact

Install backfill around water control structure in 12 inch lifts and compact making sure structure does not distort

Final grading and shaping of backfill will blend into surrounding area

Revegetate all disturbed areas with native vegetation

Cut stop logs and wedges and install in water control structure

Equipment Specrications

Track Mounted Excavator -- Komatsu PC1 50 with bucket thumb or equivalent.

Rubber-Tired Front-End Loader -- John Deere 624 with 3 - 4 yard bucket or equivalent.

$M Q$

Component

Excavation of Trench and Water Control Structure Area

Excavation of Outlet Channel

Excavation of Inlet Pond

Subgrade - 3/4-inch Minus Crushed Rock

Water Control Structure

Outlet Pipe

Pipe Couplers

Backfill Material (reuse excavated material)
Quantity

40 cu yds

5 cu yds

10 cu yds

8 cu yds

1 ea

$30 \mathrm{ft}$

2 ea

$40 \mathrm{cu}$ yds 
ITE

Component

Time Required

Excavation of Trench and Water Control Structure Area

$1.0 \mathrm{hrs}$

Excavation of Outlet Channel

Excavation of Inlet Pond

Installation of Subgrade

Assembly of Water Control Structure

Installation of Water Control Structure

Installation of Outlet Pipe

Installation and Compaction of Backfill

Construction Supervision

$0.5 \mathrm{hrs}$

$0.5 \mathrm{hrs}$

$2.0 \mathrm{hrs}$

$12.0 \mathrm{hrs}$

$2.0 \mathrm{hrs}$

$2.0 \mathrm{hrs}$

$2.0 \mathrm{hrs}$

$9.0 \mathrm{hrs}$

CE

Component

Cost

Equipment

Excavator

Front-End Loader

9 hrs@\$90.00/hr

9hrs@\$80.00/hr

S 810.00

720.00

Labor

Water Control Structure Assembty

Subgrade Installation

Water Control Structure Installation

Outlet Pipe Installation

Backfill Installation and Compaction

Construction Supervision

12 hrs@\$50.00/hr

600.00

2 hrs@\$50.00/hr

2 hrs@\$50.00/hr

2 hrs@\$50.00/hr

100.09

100.90

2 hrs@\$50.00/hr

100.00

9 hrs@\$60.00/hr

100.00

540.00

Materials

Water Control Structure

Outlet Pipe

Pipe Couplers

Subgrade Material

stop Logs

1 ea
$30 \mathrm{ft}$
2 e a
8 cu yds
8 e a

TOTAL COST
$1,395.00$

150.00

20.00

100.00

30.00

$\$ 4,765.00$ 
Water Control Structure \#5

\section{Constructron Specrications}

Construction Sequence

Identify location of new water control structure and outlet pipe

Excavate a trencn 6 feet wide through dike for outlet pipe to elevation 2034

Remove existing pipe aunng excavation of trench

Excavate around water control structure location to elevation 2033

Excavate inlet pond and trencn to islands to elevation 2037

Place 3/4-inch minus crusnea rock in trench and area around water control structure and compact to depth of 6 incnes

Assemble water control structure and install with bottom at elevation 2033.5

Assemble outlet pipe, attach to water control structure, and install at elevation 2034.5

Install backfill around outlet pipe in 12 inch lifts and compact

Install backfill around water control structure in 12 inch lifts and compact making sure structure does not distort

Final grading and shaping of backfill will blend into surrounding area

Revegetate all disturbed areas with native vegetation

Cut stop logs and wedges and install in water control structure

Equipment Specifications

Track Mounted Excavator -- Komatsu PC1 50 with bucket thumb or equivalent.

Rubber-Tired Front-End Loader -- John Deere 624 with $3-4$ yard bucket or equivalent.

\section{MO}

Component

Quantity

Excavation of Trench and Water Control Structure Area

Excavation of Inlet Pond and Trench to Islands

Subgrade - 3/4-inch Minus Crushed Rock

Water Control Structure

Outlet Pipe

Pipe Couplers

Backfill Matenal (reuse excavated material)

$50 \mathrm{cu}$ yds

$400 \mathrm{cu}$ yds

9 cu yds

1 ea

$36 \mathrm{ft}$

2 ea

$75 \mathrm{cu}$ yds 
ITE

Component

Time Required

Excavation of Trench and Water Control Structure Area

$1.0 \mathrm{hrs}$

Excavation of Inlet Pond and Trench to Islands

$4.0 \mathrm{hrs}$

Installation of Subgrade

Assembly of Water Control Structure

Installation of Water Control Structure

$2.0 \mathrm{hrs}$

Installation of Outlet Pipe

Installation and Compaction of Backfill

Construction Supervision

$12.0 \mathrm{hrs}$

$2.0 \mathrm{hrs}$

$2.0 \mathrm{hrs}$

$2.0 \mathrm{hrs}$

$11.0 \mathrm{hrs}$

CE

Component

cost

Equipment

Excavator

Labor

Front-End Loader

11 hrs@\$90.00/hr

11 hrs@\$80.00/hr

s 990.00

880.00

Water Control Structure Assembly

12 hrs@\$50.00/hr

606.00

Subgrade Installation

Water Control Structure Installation

Outlet Pipe Installation

Backfill Installation and Compaction

Materials

Construction Supervision

2 hrs@\$50.00/hr

100.00

2 hrs@\$50.00/hr

100.00

2 hrs@\$50.00/hr

106.00

2 hrs@\$50.00/hr

100.00

11 hrs@\$60.00/hr

660.00

Water Control Structure

1 ea

Outlet Pipe

Pipe Couplers

Subgrade Material

stop Logs

$\begin{array}{rl}36 & \mathrm{ft} \\ 2 & \text { ea } \\ 9 & \mathrm{cu} \text { yds } \\ 10 & \text { ea }\end{array}$

TOTAL COST
$2,120.00$

180.06

20.60

115.00

40.00

$\$ 6,005.00$ 
Water Control Structure \#6

\section{Construction Specifications}

\section{Construction Sequence}

Layout alignment of new road/dike

Identify location of new water control structure and outlet pipe

Excavate a trench 6 feet wide in existing road to elevation 2039.5

Remove existing pipes during excavation of trench

Excavate around water control structure to elevation 2038.5

Excavate wetland adjacent to water control structure to elevation 2040

Place 3/4-inch minus crushed rock in trench and area around water control structure and compact to depth of 6 inches

Assemble outlet pipe, attach to water control structure, and install with bottom at elevation 2040

Remove unused pipe near west end of road and discard

Remove and replace pipe in irrigation ditch with new culvert

Install fill material for road/dike in 6-inch lifts and compact

Revegetate top and faces of road/dike with native vegetation

Cut stop logs and wedges and install in water control structure

Equipment Specifications

Track Mounted Excavator -- Komatsu PC150 with bucket thumb or equivalent.

Rubber-Tired Front-End Loader -- John Deere 624 with 3 - 4 yard bucket or equivalent.

Dump Truck -- Twin axle with 10-12 cubic yard dump box and end gate.

$M Q$

Component

Excavation of Trench and Water Control Structure Area

Excavation of Upstream and Downstream Wetlands

Subgrade - 3/4-inch Minus Crushed Rock

Water Control Structure

Outlet Pipe

Pipe Couplers

Irrigation Ditch Culvert

Fill Material for Road/Dike
Quantitv

10 cuyds

220 cu yds

3 cuyds

1 ea

$28 \mathrm{ft}$

2 ea

$20 \mathrm{ft}$

$750 \mathrm{cu}$ yds 
ITE

Component

Time Required

Excavation of Trench and Water Control Structure Area

$0.5 \mathrm{hrs}$

Excavation of Upstream and Downstream Wetlands

Installation of Subgrade

Assembly of Water Control Structure

$2.5 \mathrm{hrs}$

$1.0 \mathrm{hrs}$

Installation of Water Control Structure

$12.0 \mathrm{hrs}$

$2.0 \mathrm{hrs}$

Installation of Outlet Pipe

Installation of Irrigation Ditch Culvert

Installation and Compaction of Road/Dike Pill Material

Construction Supervision

$2.0 \mathrm{hrs}$

$2.0 \mathrm{hrs}$

$24.0 \mathrm{hrs}$

$32.0 \mathrm{hrs}$

CE

Component

Cost

Equipment

Excavator

Front-End Loader

Dump Truck

Labor

Water Control Structure Assembty

Subgrade Installation

Water Control Structure Installation

Outlet Pipe Installation

Irrigation Ditch Culvert Installation

Materials

Construction Supervision

Water Control Structure

Outlet Pipe

Pipe Couplers

Subgrade Material

Irrigation Ditch Culvert

Stop Logs

32 hrs@\$90.00/hr

32 hrs@\$80.00/hr

24 hrs@\$60.00/hr

$\$ 2,880.00$

$2,560.00$

$1,440.00$

12 hrs@\$50.00/hr

1 hrs@\$50.00/hr

2 hrs@\$50.00/hr

2 hrs@\$50.00/hr

2 hrs@\$50.00/hr

32 hrs @ \$60.00/hr

600.00

50.00

100.00

100.00

100.00

$1,920.00$

1 ea

$28 \mathrm{ft}$

2 ea

6 cu yds

965.00

140.00

20.00

75.00

$20 \mathrm{ft}$

100.00

4 ea

15.00

TOTAL COST

$\$ 11.065 .00$ 


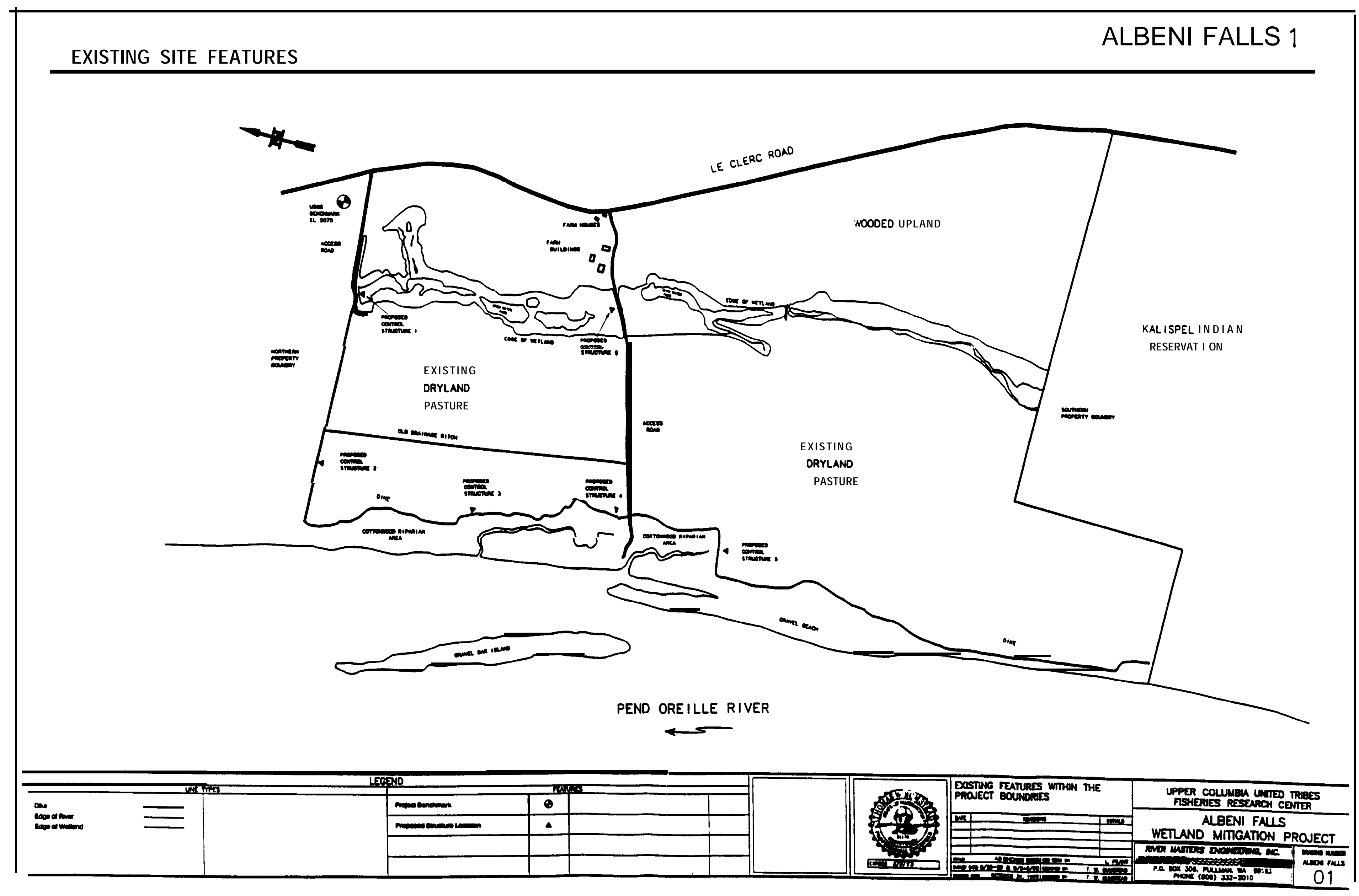




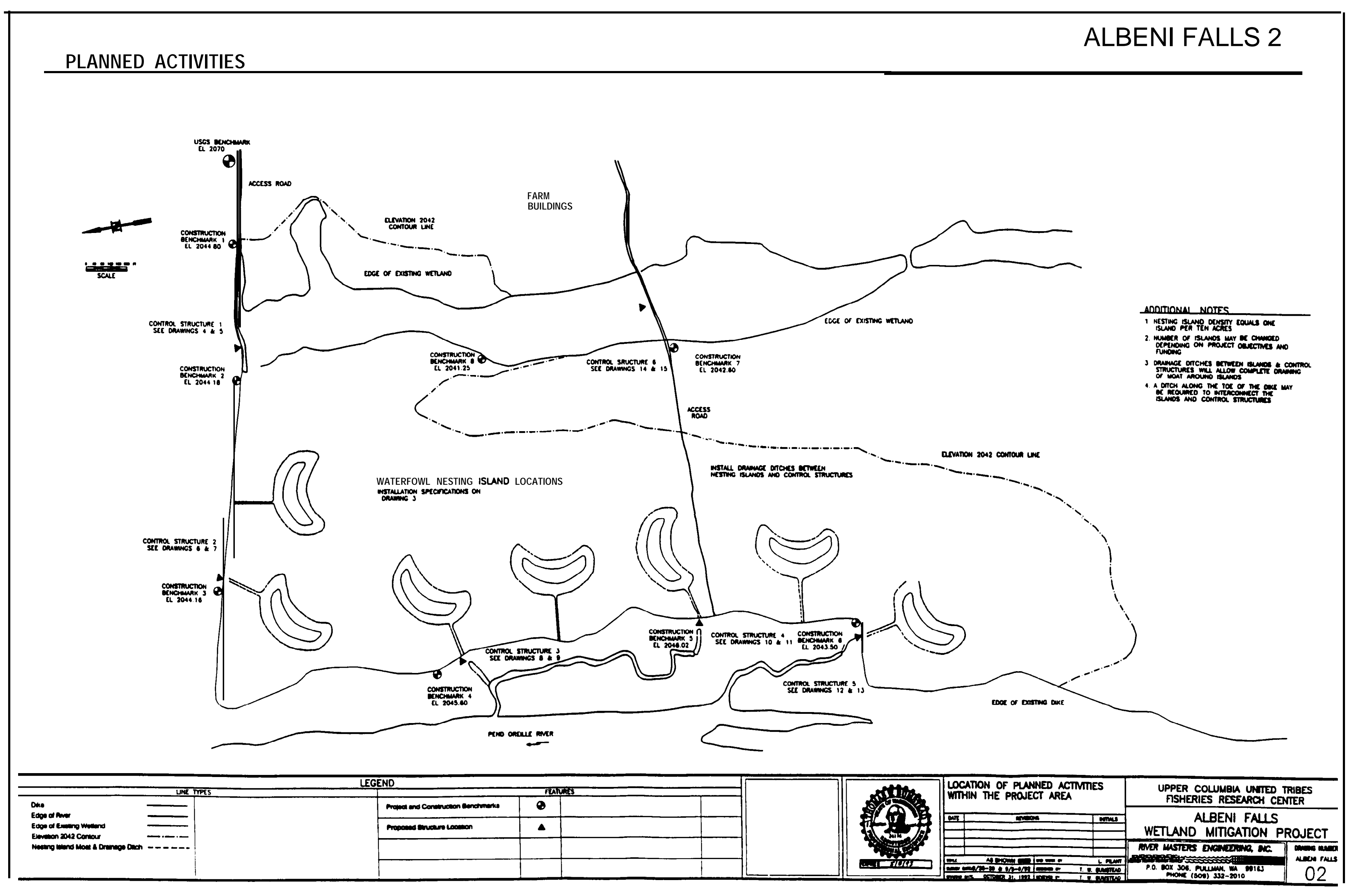




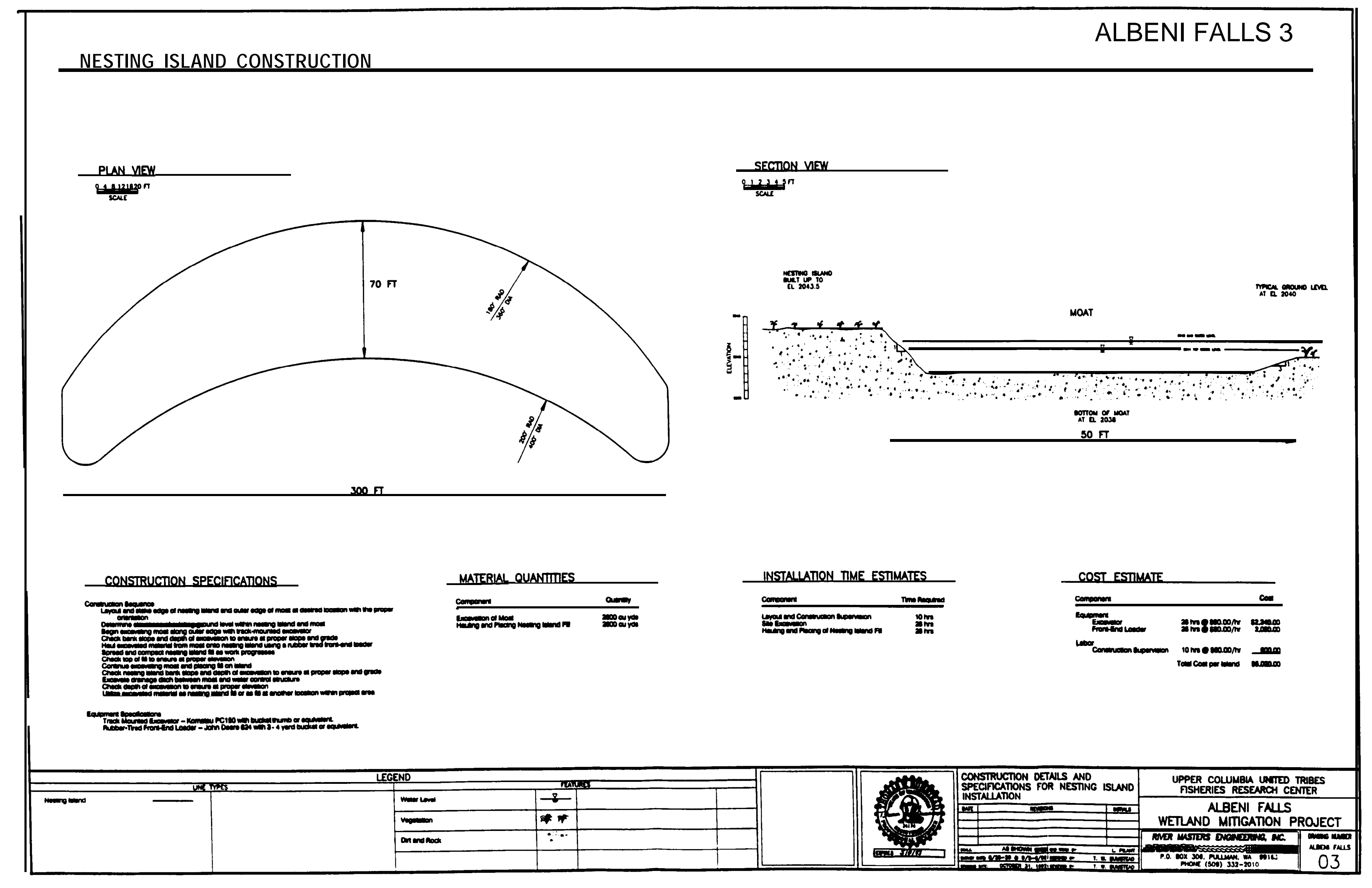




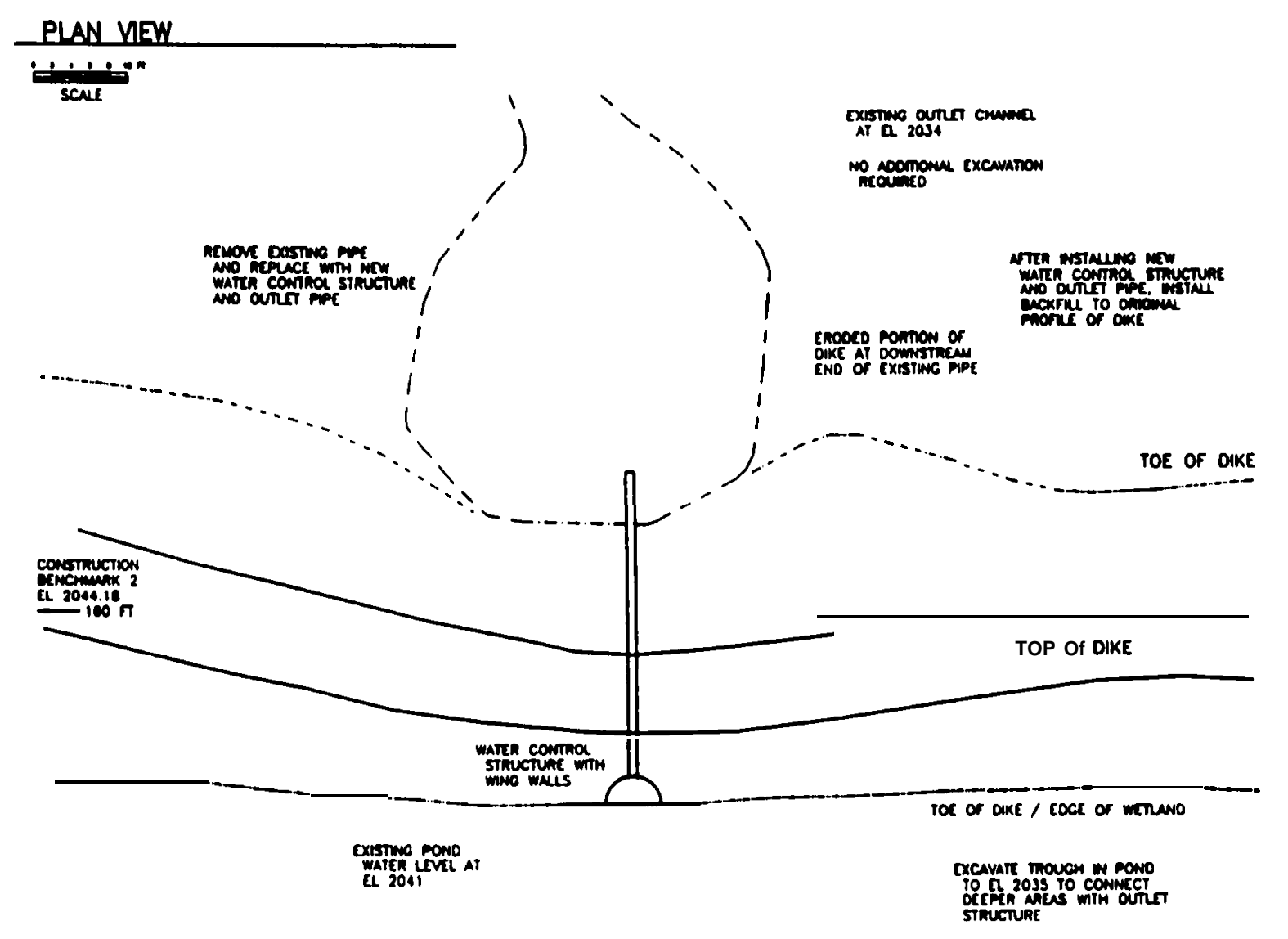

SECTION VIEW

sous

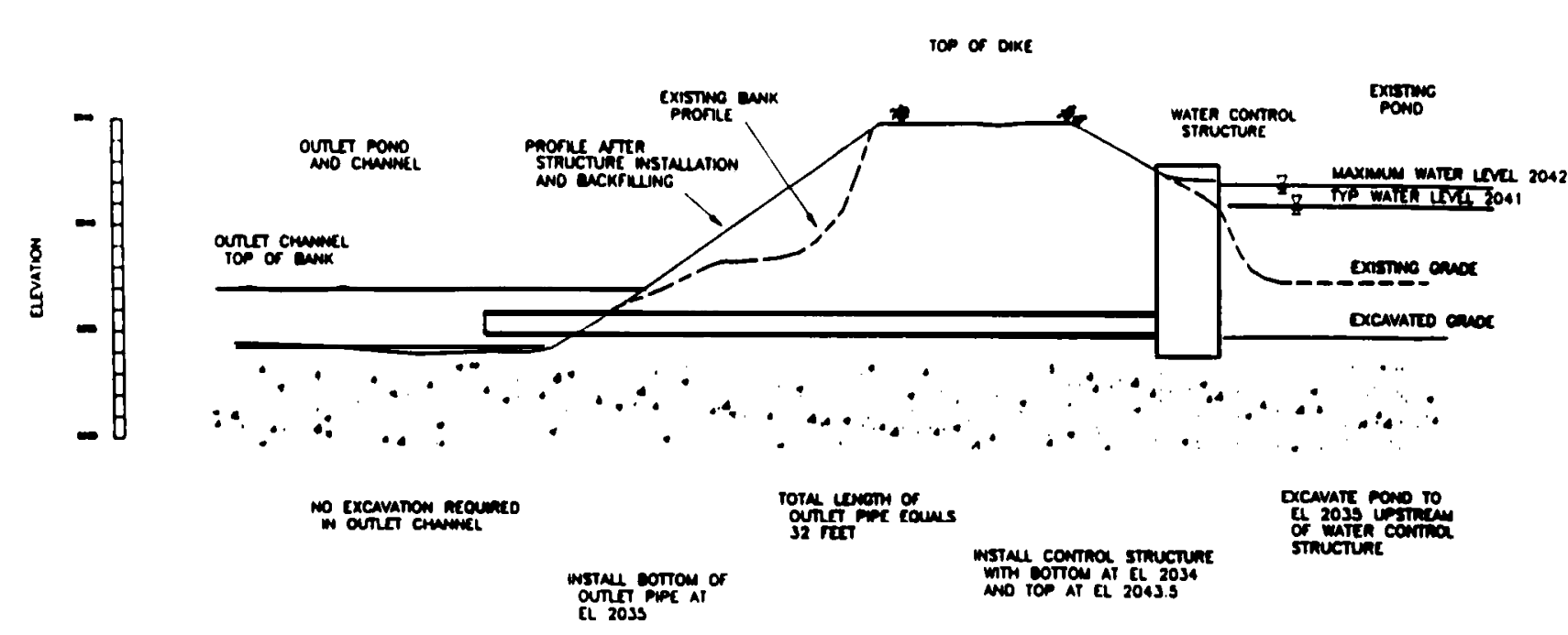

CONSTRUCTION SPECIFCATIONS
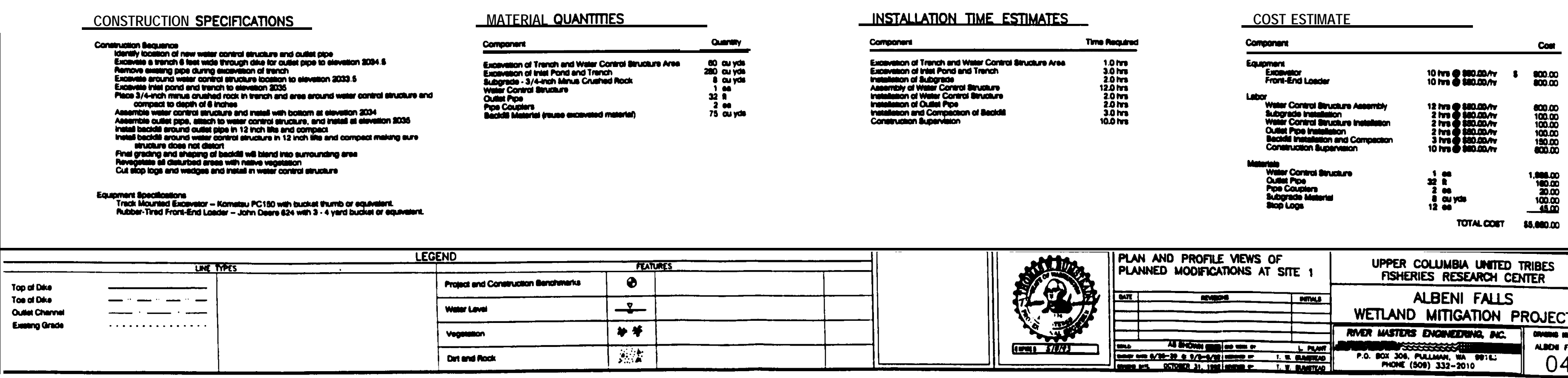

\begin{tabular}{|c|c|c|}
\hline \multicolumn{2}{|c|}{$\begin{array}{l}\text { PUW NWD PROFLE MEWS OF } \\
\text { PWWNED MOOFTCATONS AT STE I }\end{array}$} & $\begin{array}{l}\text { UPPER COUMBU WWIED TRIBES } \\
\text { PSHERIES RESEAROH CENIER }\end{array}$ \\
\hline and & annos & $\begin{array}{l}\text { ALBENI FNUS } \\
\text { WETLANO MITGATION PROJECT }\end{array}$ \\
\hline & 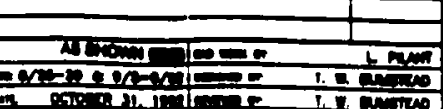 & 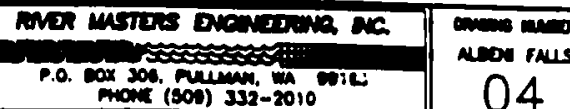 \\
\hline
\end{tabular}




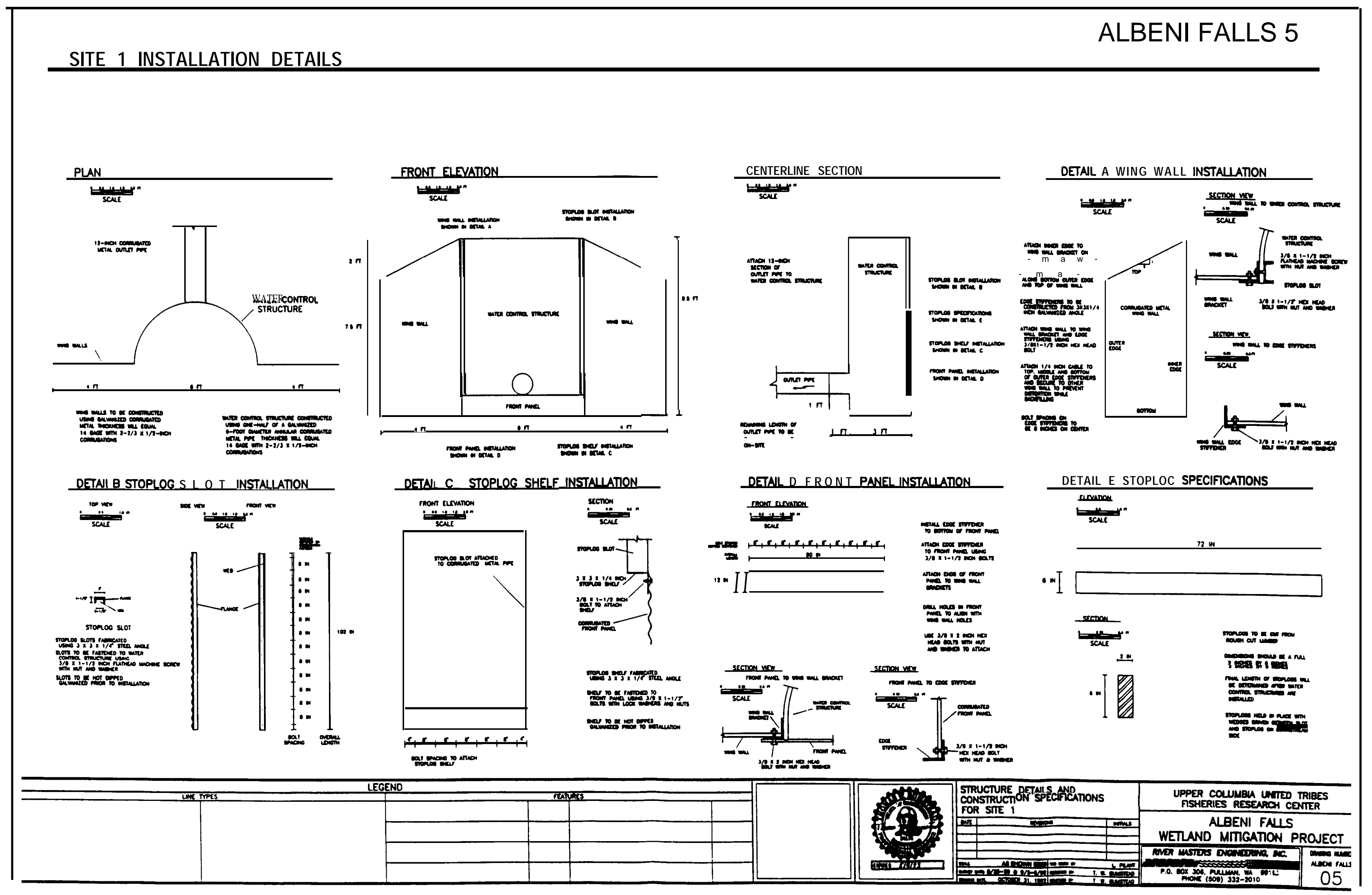




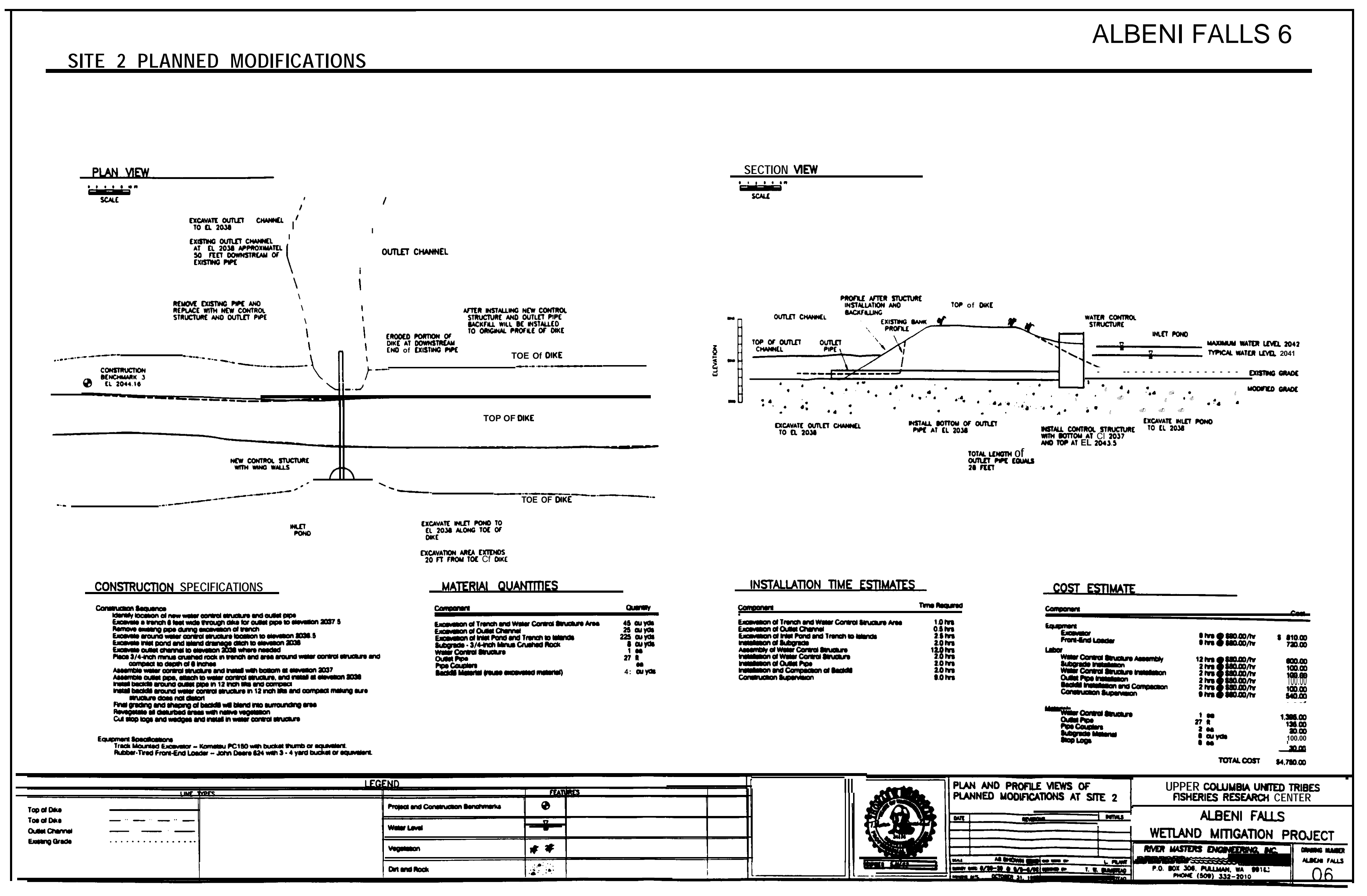



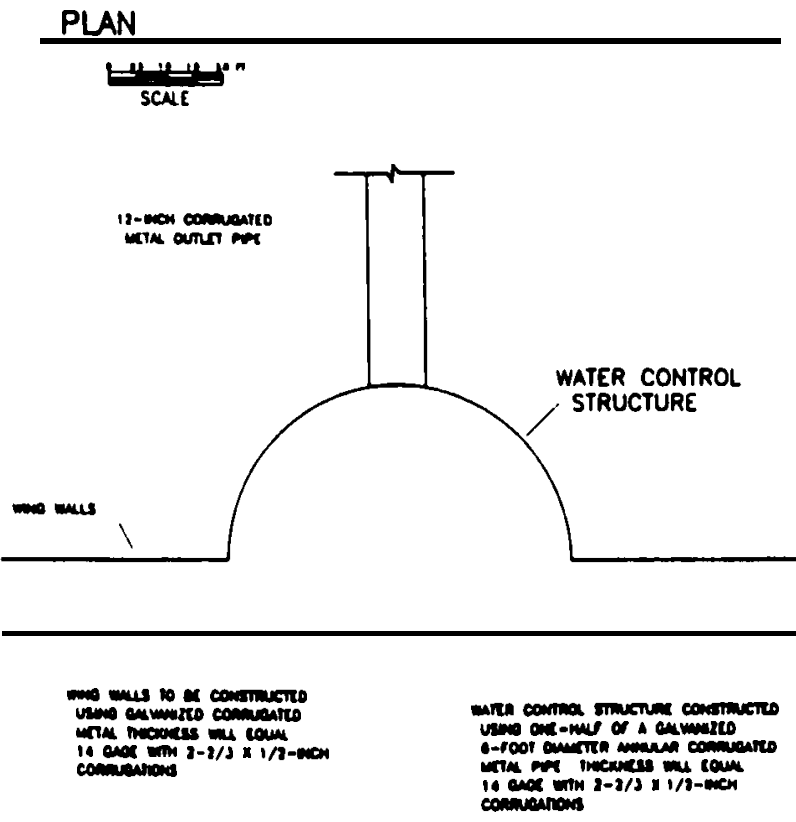

DETAL B STOPLDC SLOT INSTALLATION

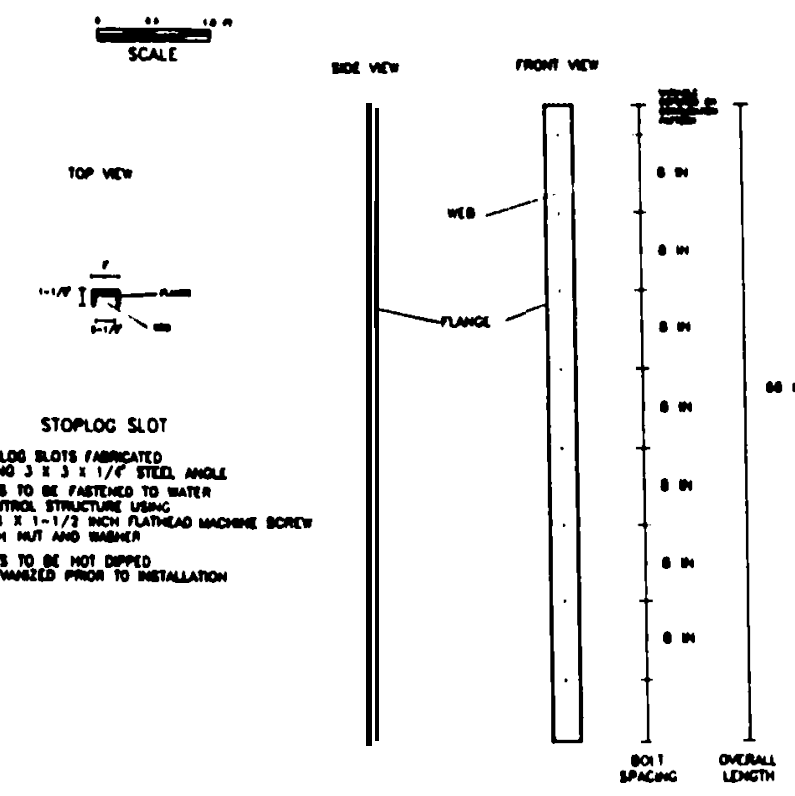

FRONT ELFYATON

Evate-"

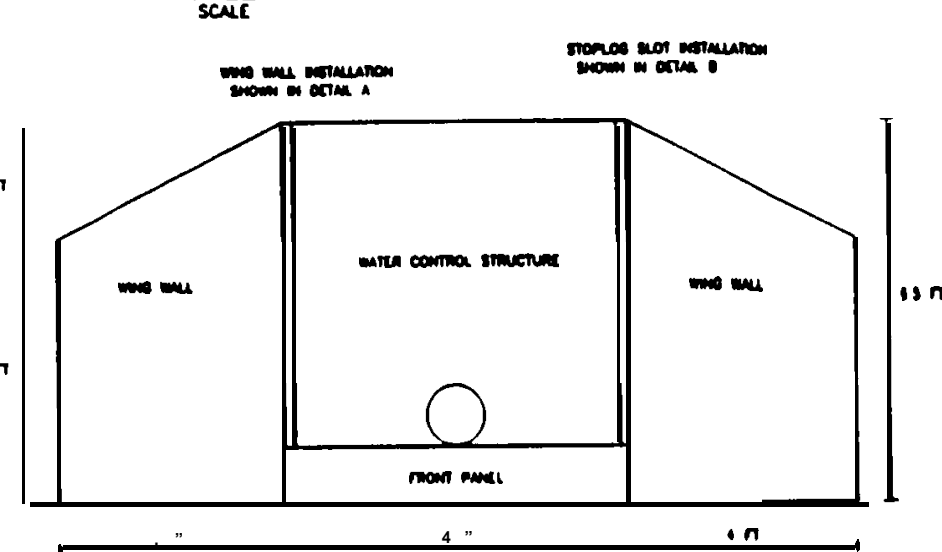

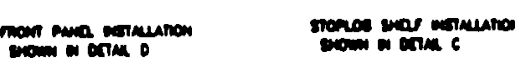

DETAIL C STOPLOC SHELF INSTALLATION

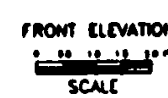
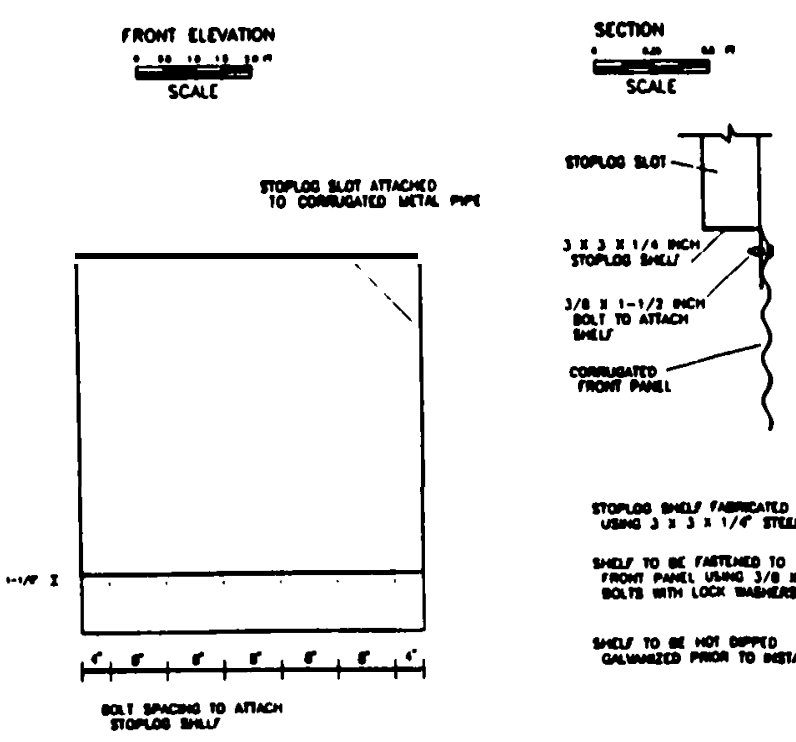

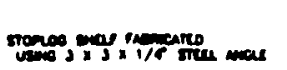
Fand

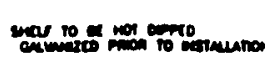

CENTERLINE SECTION Siston.

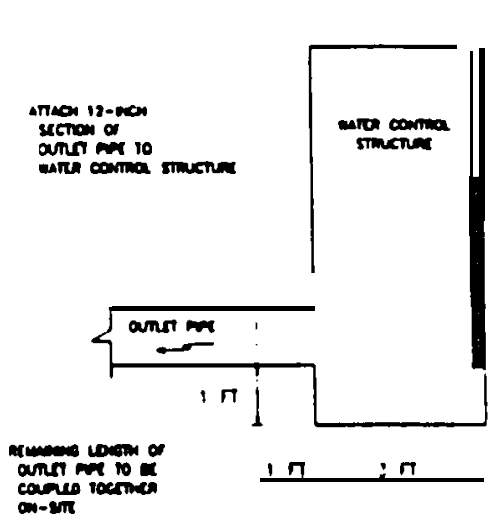

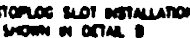
sangang simox moranow

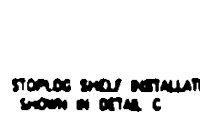

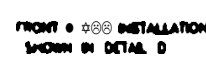

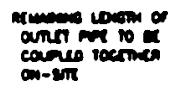

DETALL D FRONT PANEL INSTALLATON mananom

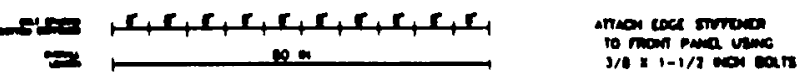
$12 \mathrm{I} T \square$

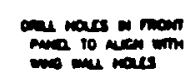

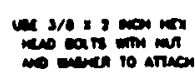

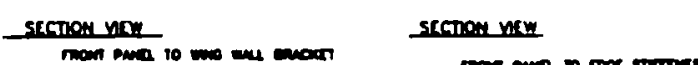

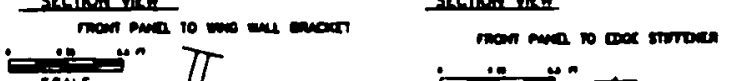
sciet" C.

DETAIL A WING WALL INSTALLATION
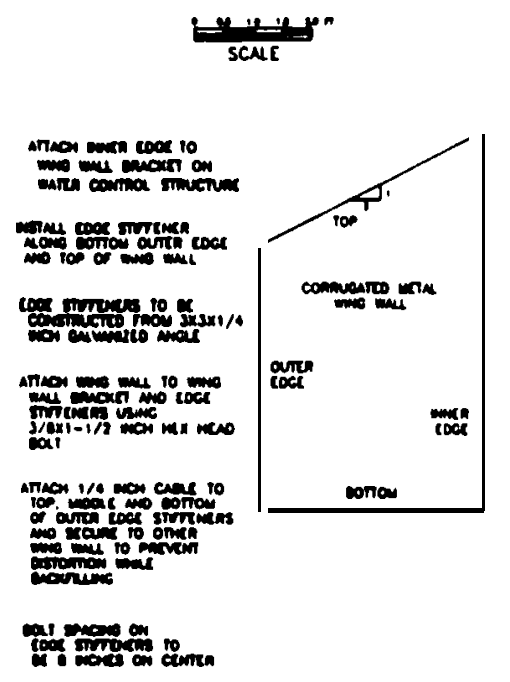

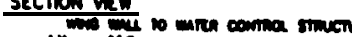

$\prod$ ingoma

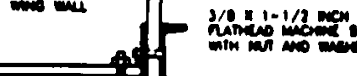

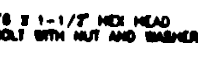
remon ins

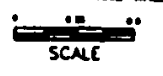

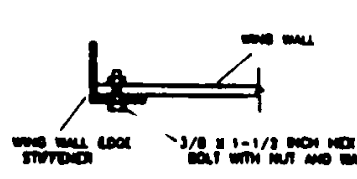

DETAL E STOPLOC SPECIFICATIONS Scure$$
n
$$

$\cdot m T$

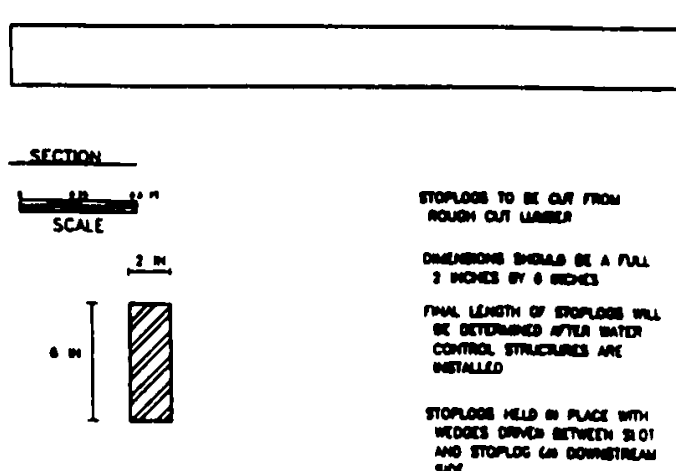

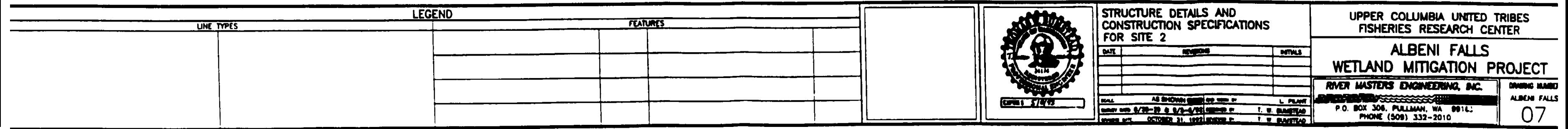




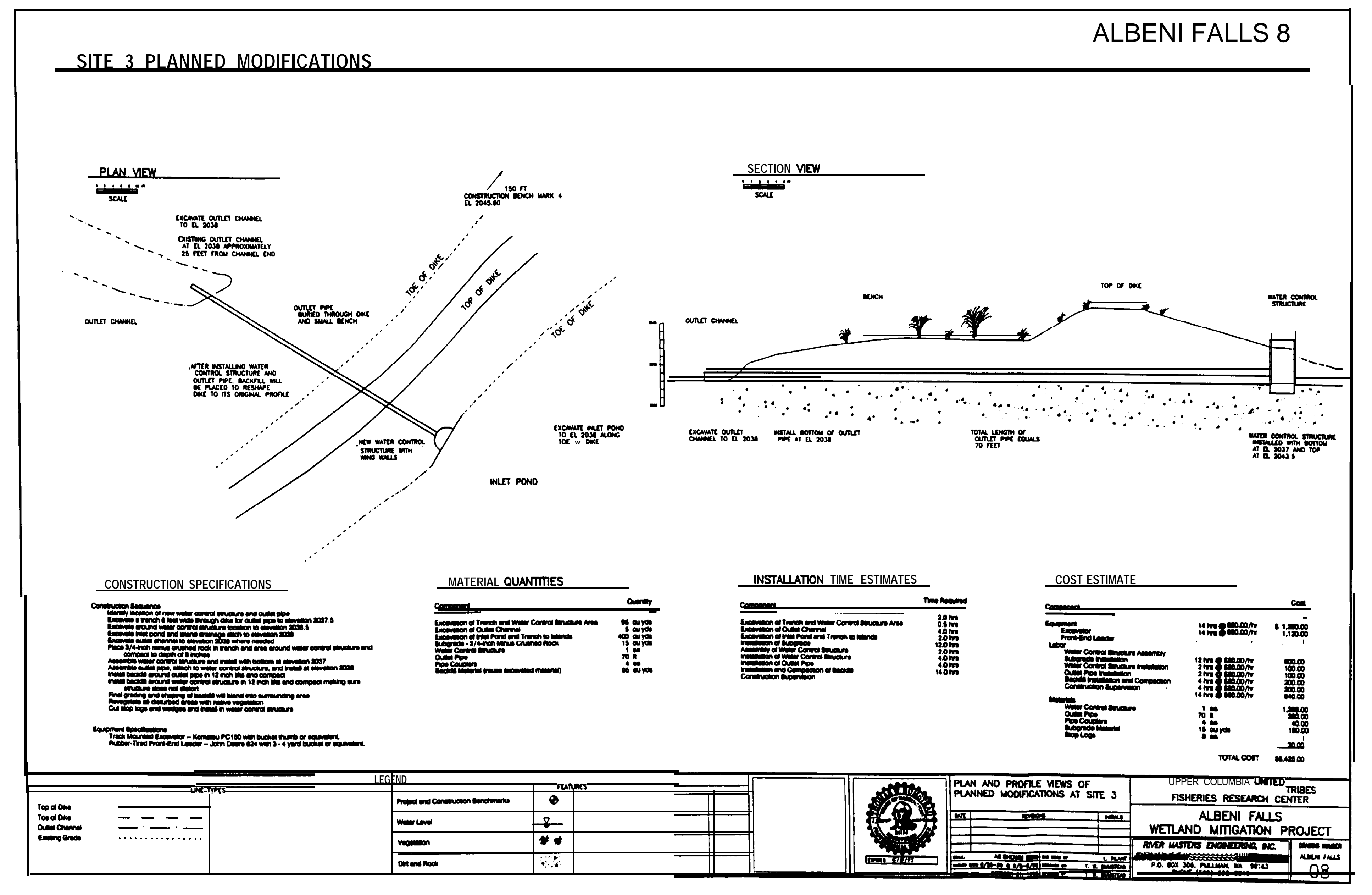




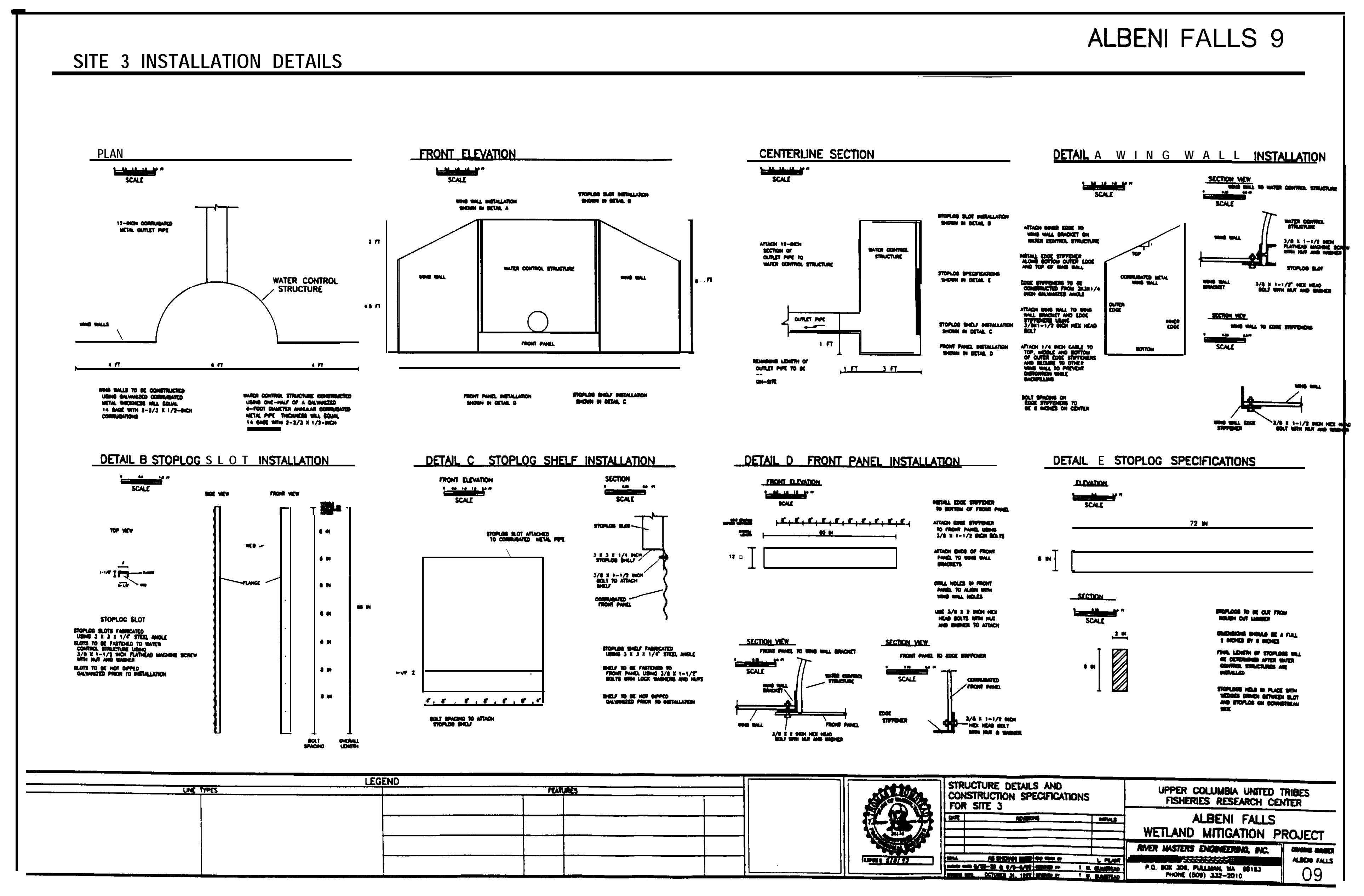



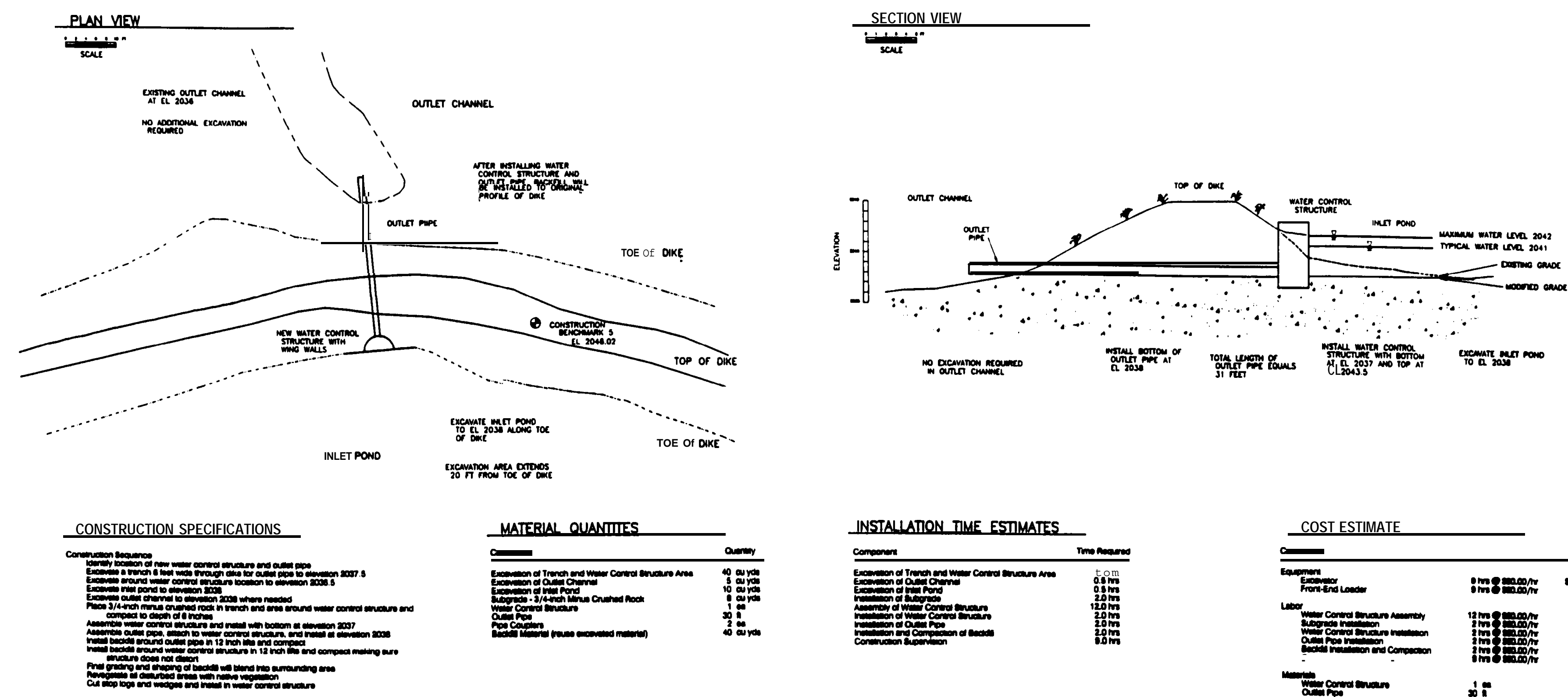

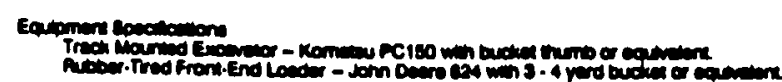

$m_{m}^{m}$

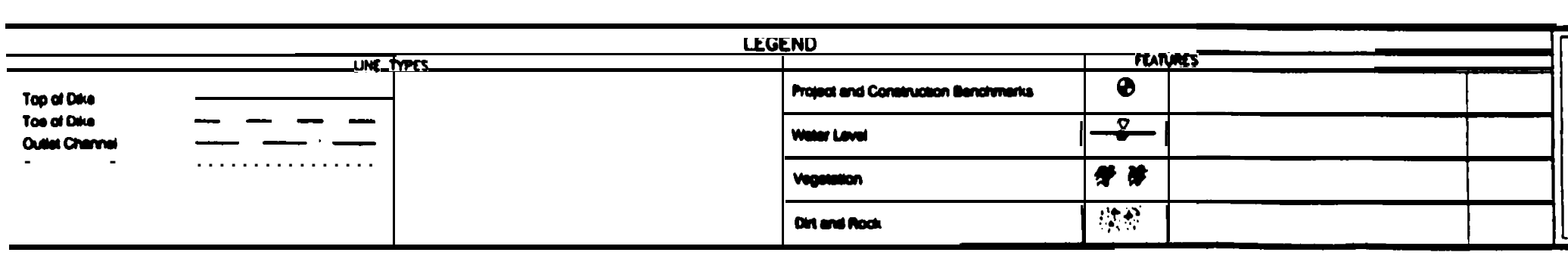

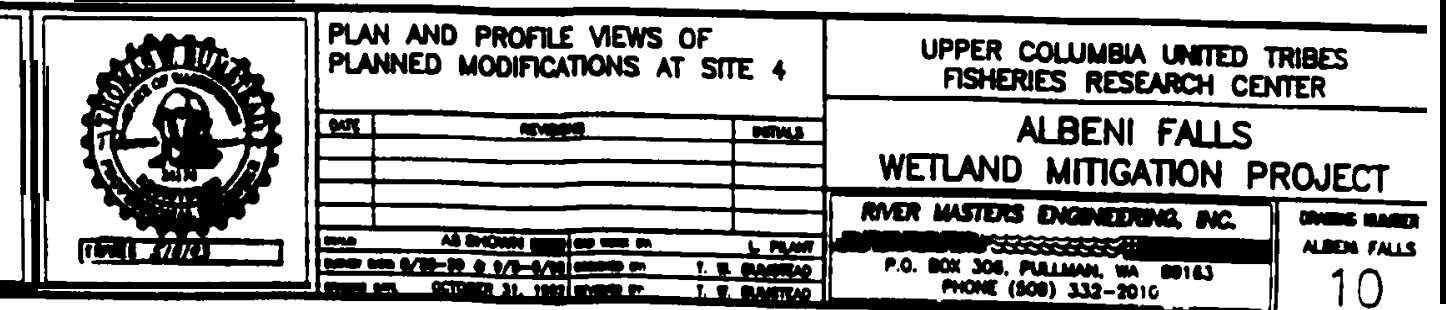



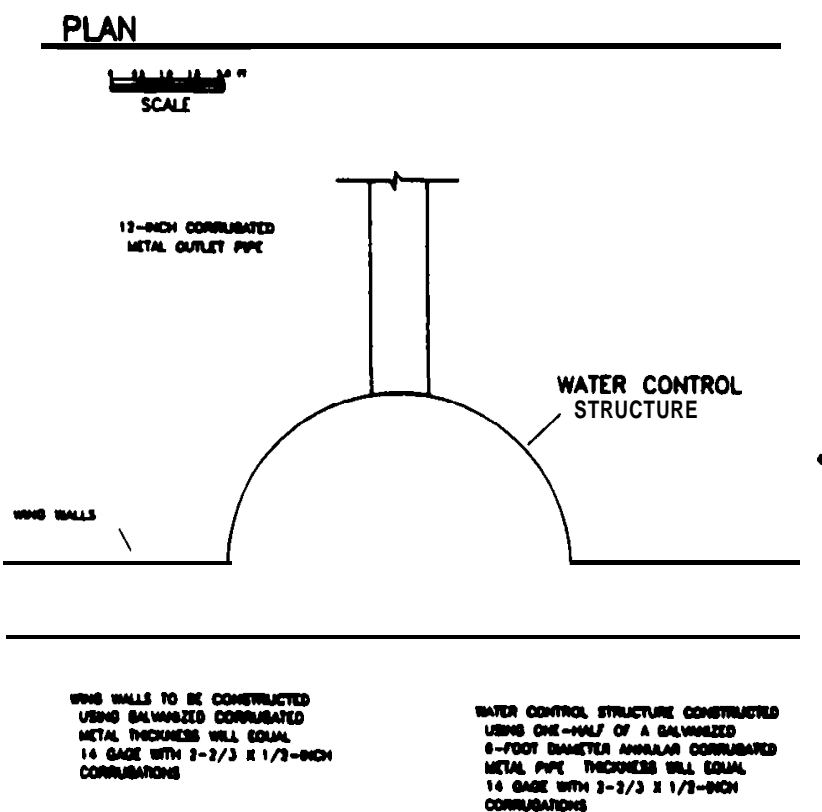

DETALL B STOPLOG_SLOIINSTALLATON

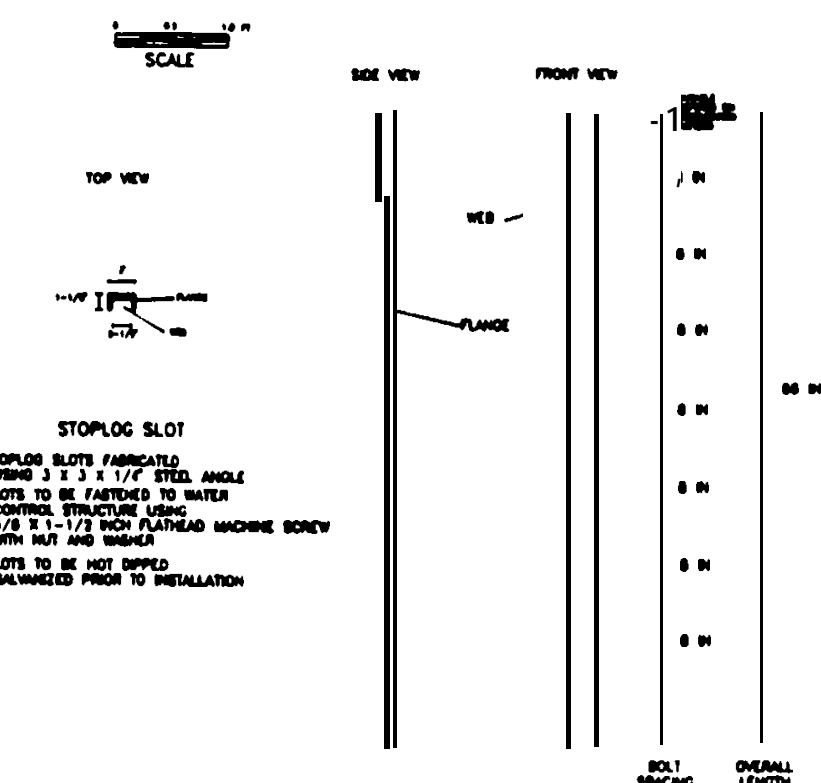

med
FRONT EIEYATION

Scunen"

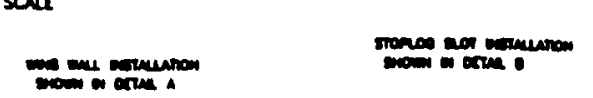

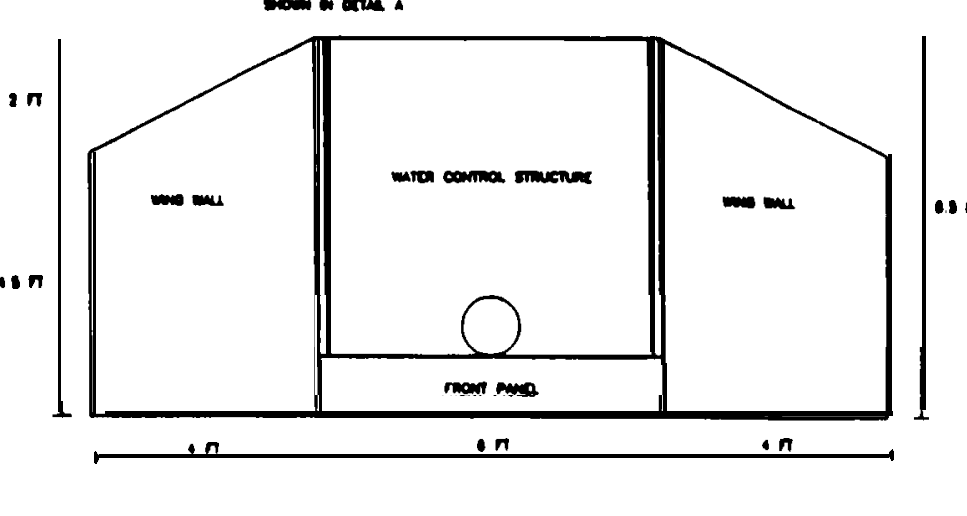

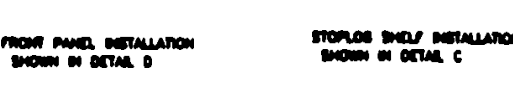

OETALC C STOPLOG SHELF INSTALLTON "mowr carvanow
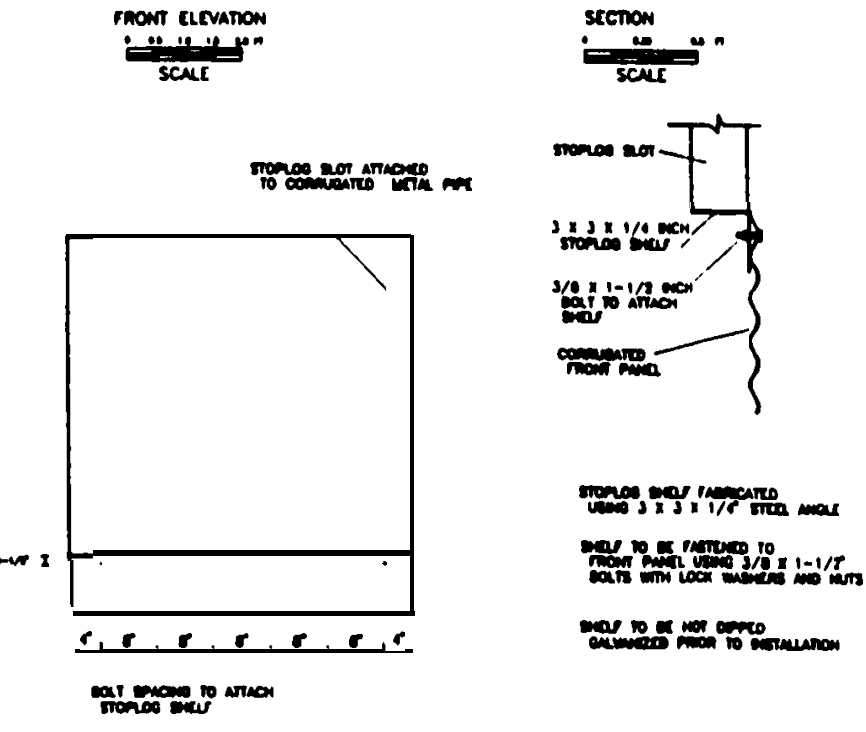

CENIERUNE SECTION

EScuren

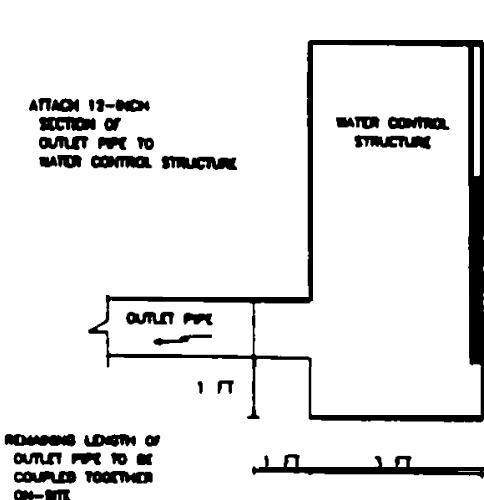

페에

DEALL D FRONT PANEL INSTALLATON

$$
\text { mascanapor }
$$

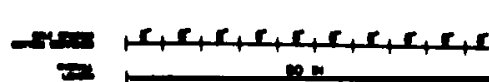

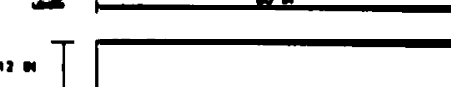

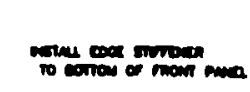

Mron $=0$

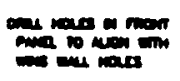
네에

scecou now

sche " $\underset{-\infty}{\longrightarrow}$

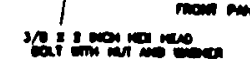

incen
DETAL A MING WAU INSTALLATION

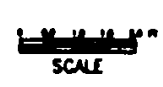

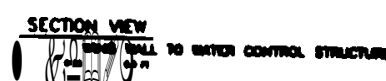

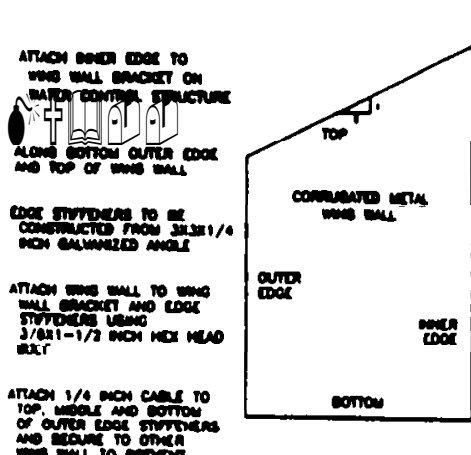

$\pi$ menoma - -2 $\Longrightarrow$ DL now eor

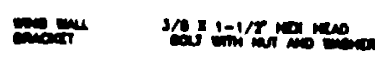

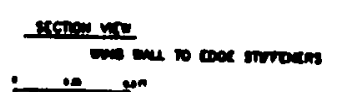
sine

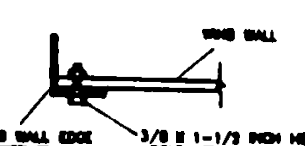

(1)

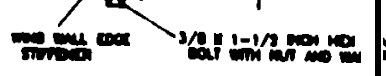

DETALL E STOPLOG SPECIFCATIONS

$$
\text { souron }
$$

sent

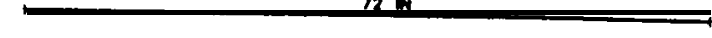

- 1

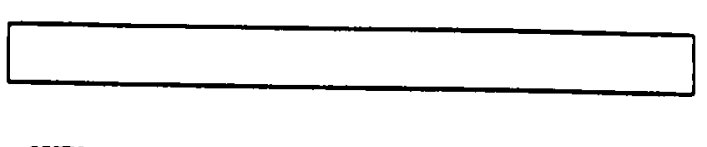

scenow

scher "x"

.

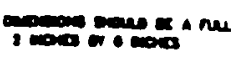

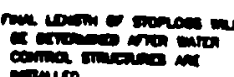

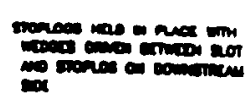

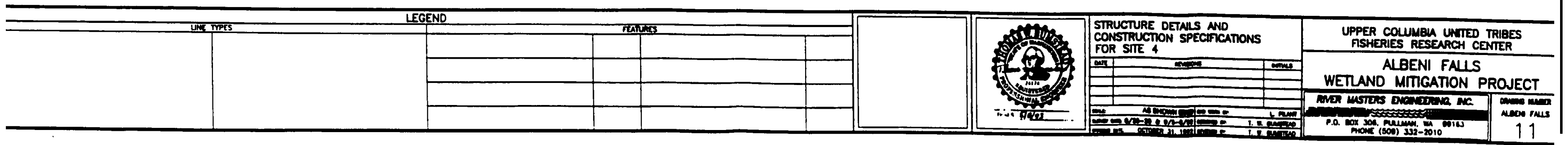




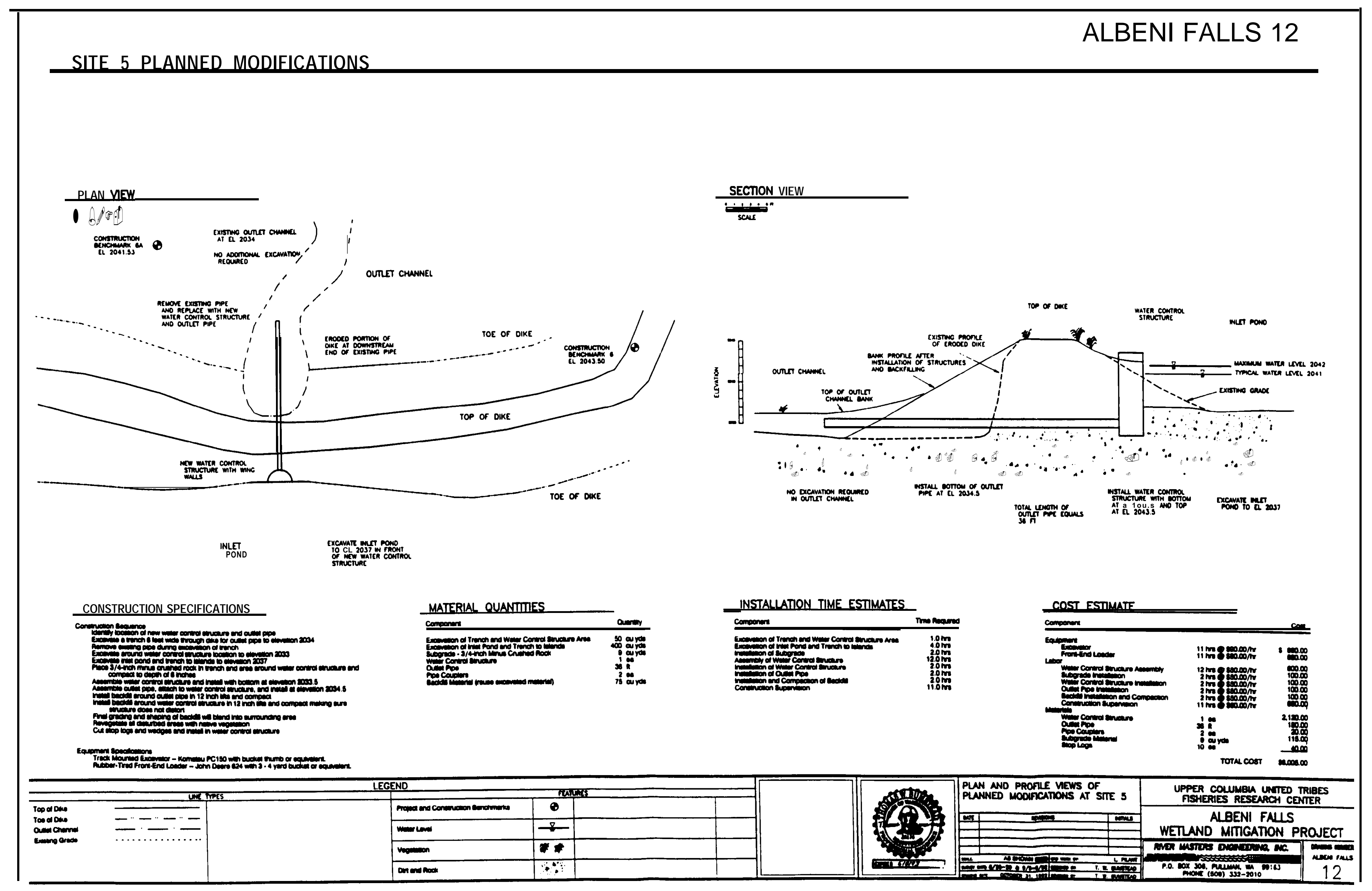




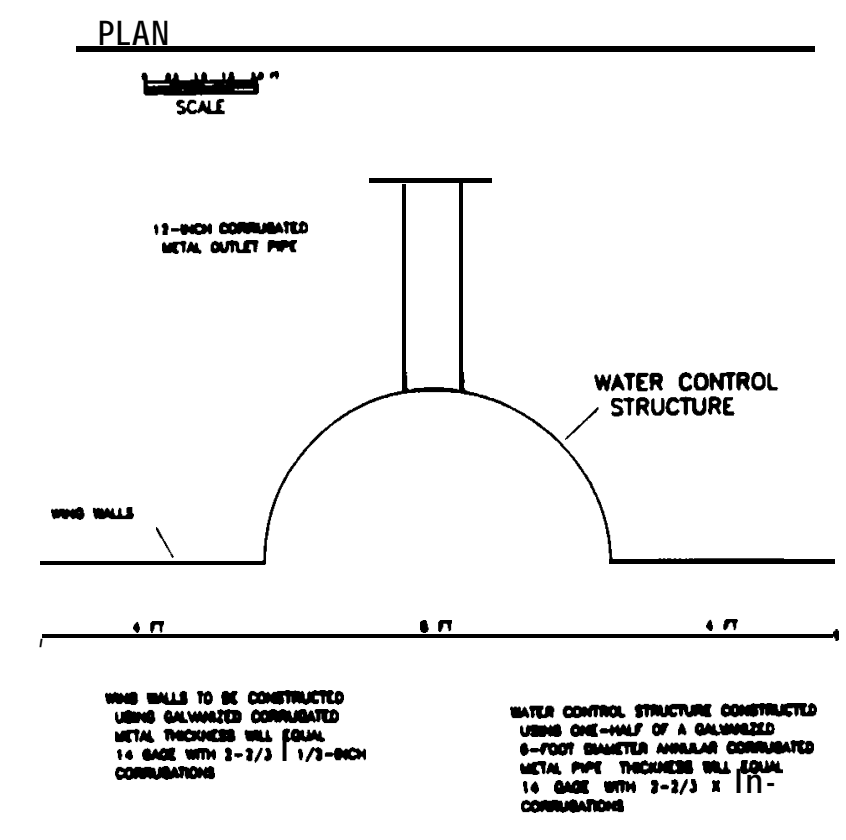

DETAII B STOPLOG S L O T INSTALLATION $\frac{1}{\mathrm{sut}}$

|cher
FRONT ELEVATION

scisen"

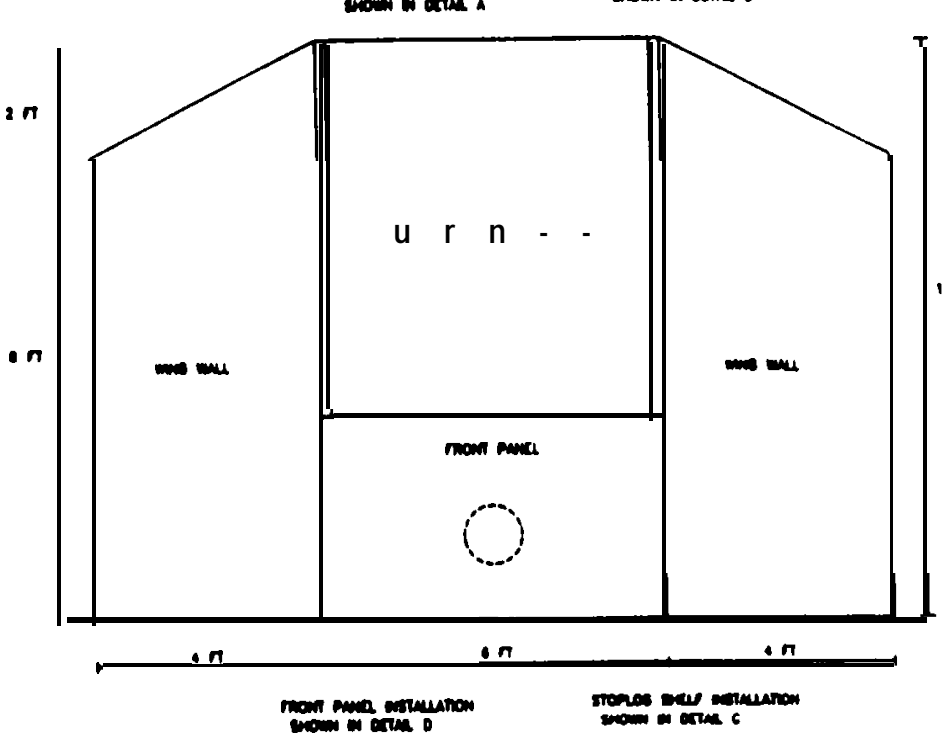

DETALL C STOPLOG SHELF INSTALATON
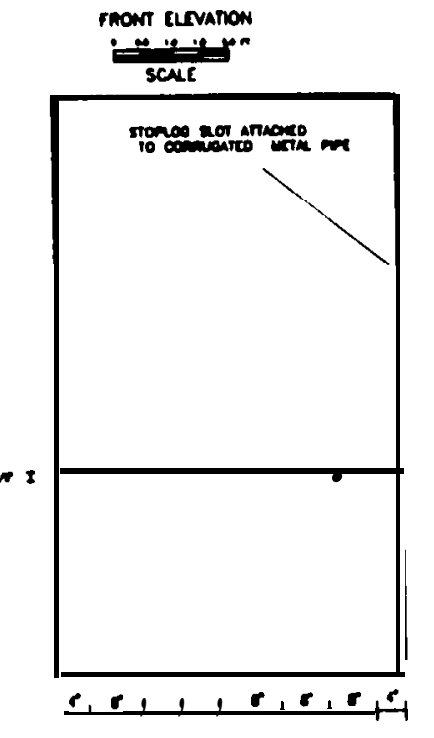

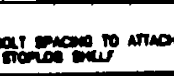
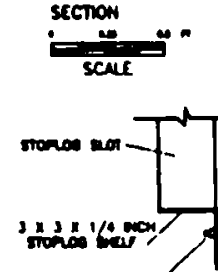

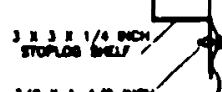

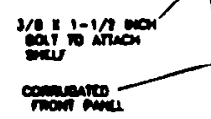

\}

monom The

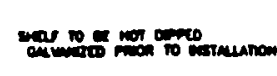

CENTERLINE SECTION

$$
\text { Hentenc" }
$$

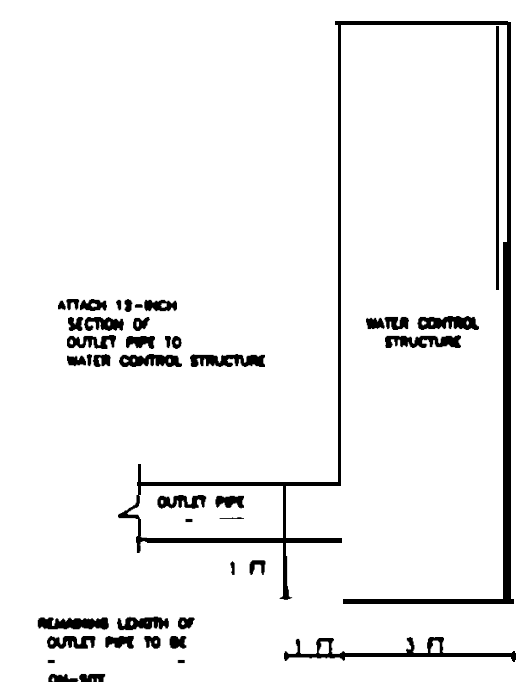

DEAALL D ERONL PANEL INSTALLATION frome curator

תبع.r.

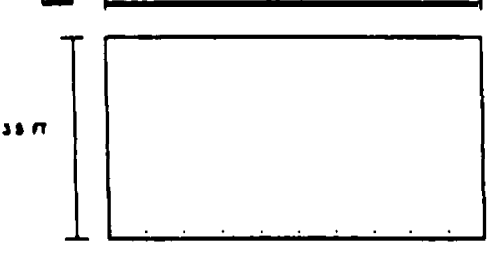

ir monai a monima

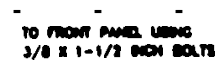
mancen

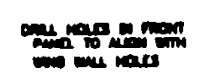
mand

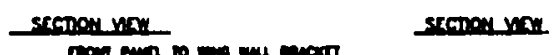

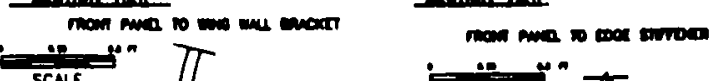

scir -
DETAL A WING WALL INSTALLATION

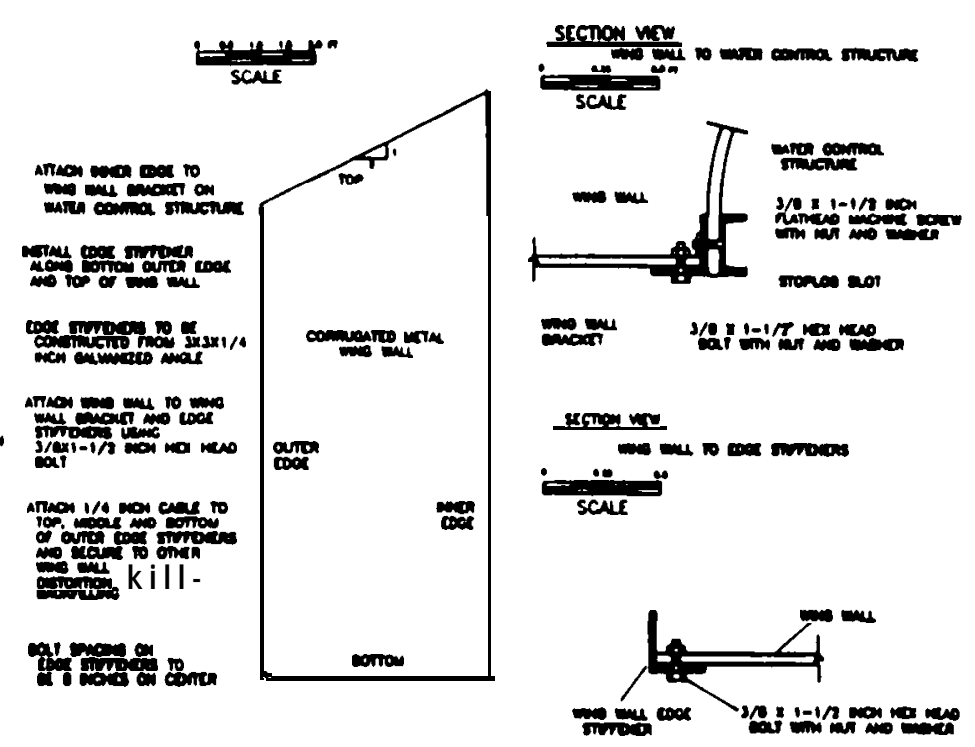

DETAL E STOPLOG SPECIFICATIONS seriran

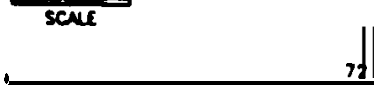

*

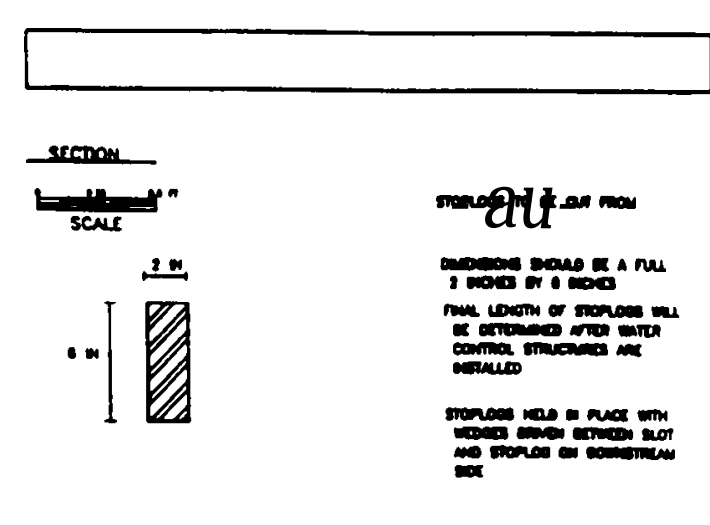

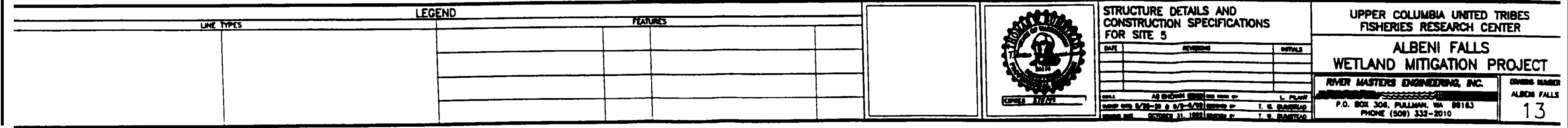




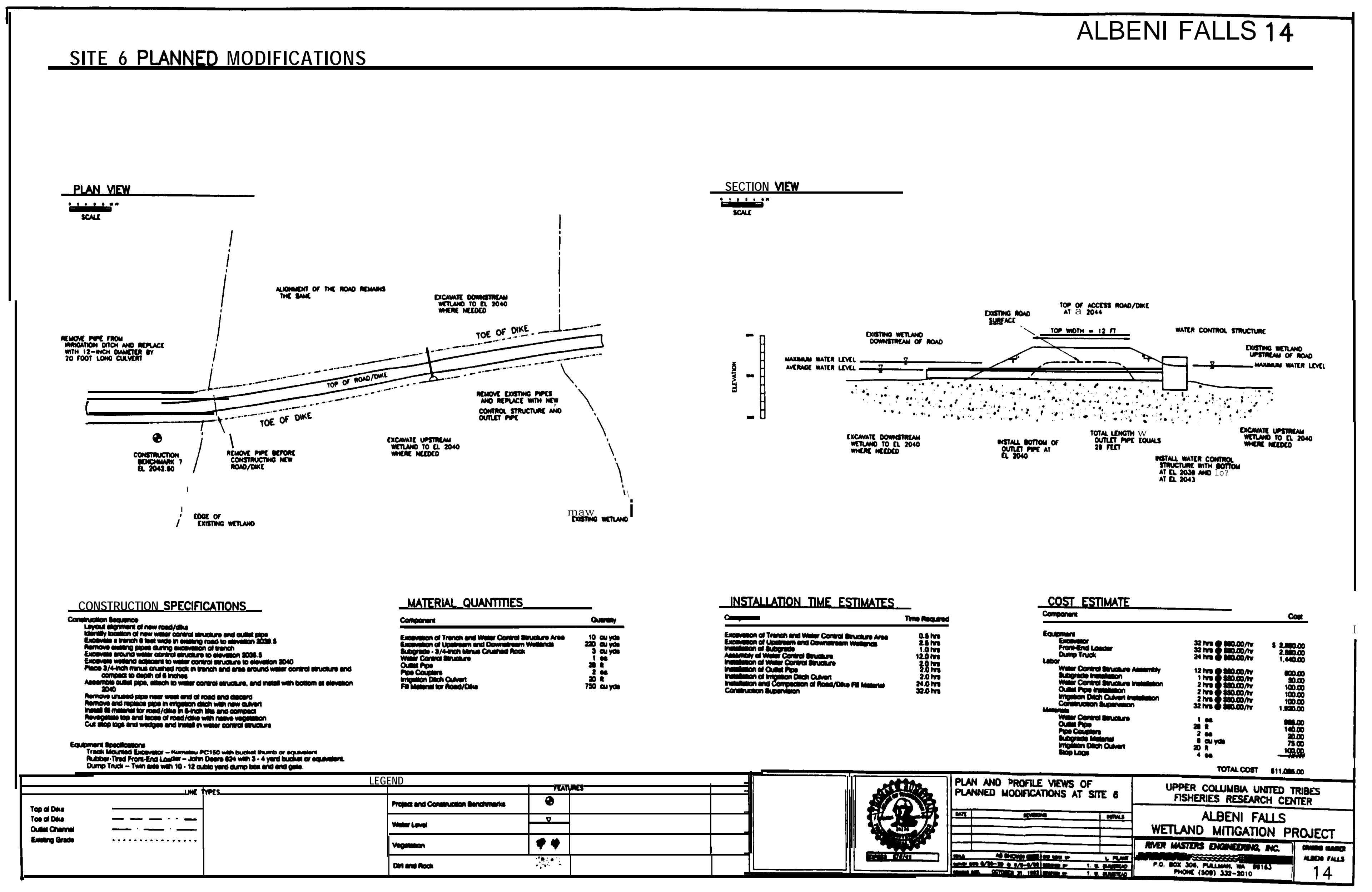



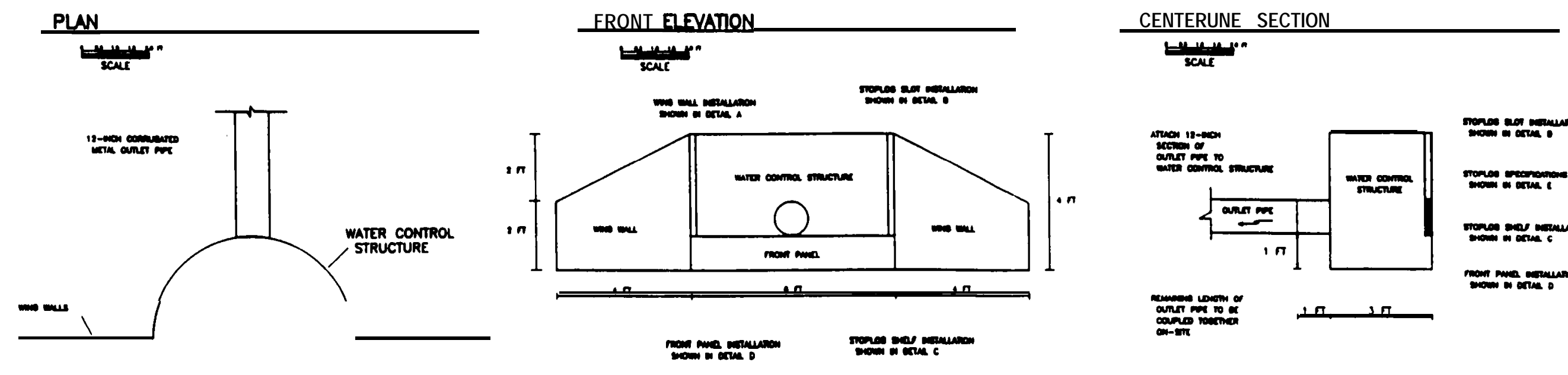

DETAL A WING WALL INSTALLATION
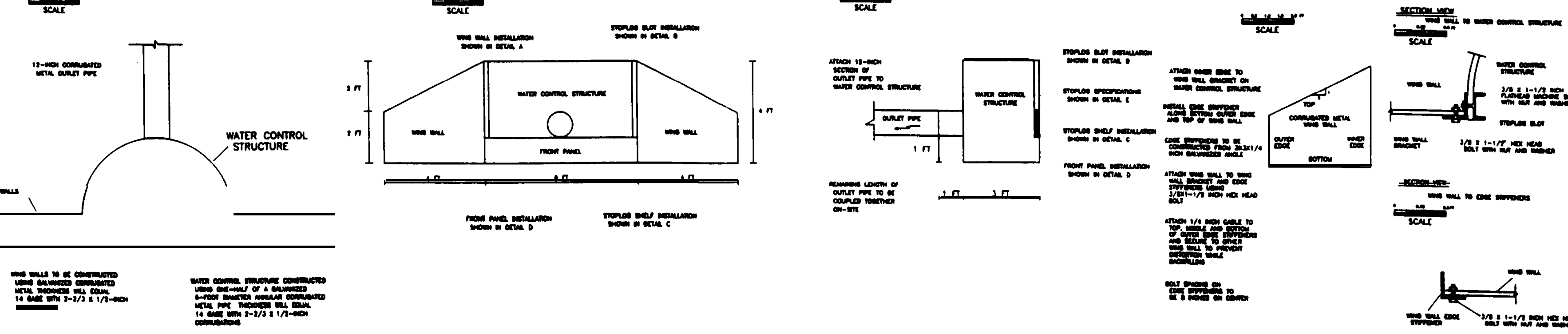

DETAL B STOPLOG_SLOT INSTALLATON

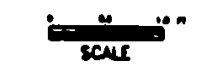

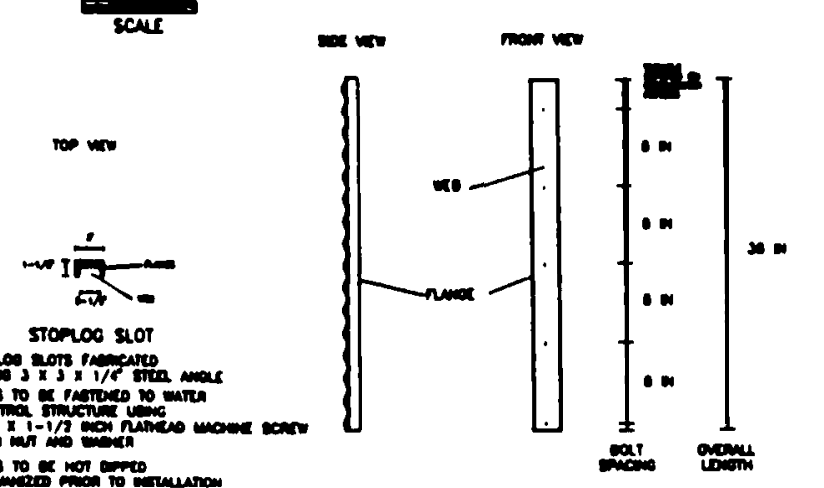

DETALC STOPLOG SHELF INSTAUATON
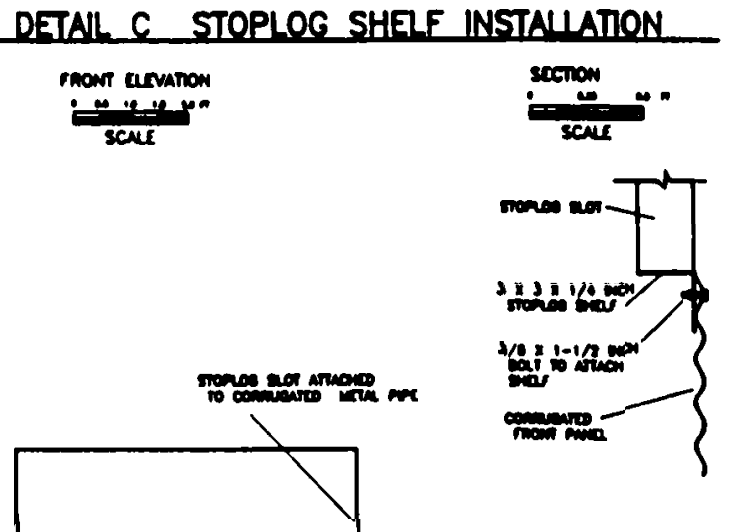

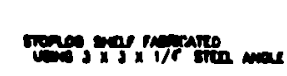

cos on comoes io

mines

DEALL O FRONT PANEL INSTALLATON

\section{rmascoumos}

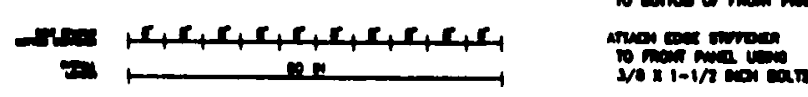

$\mathrm{N} \mid \mathrm{T}$.

$\lim _{x \rightarrow \infty}$

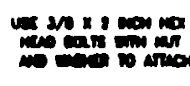

Secen iny

sche

Clil $=\min _{2}$

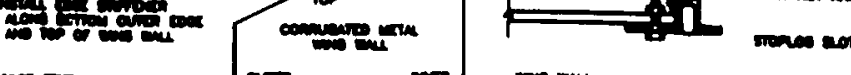
我 and

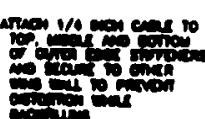

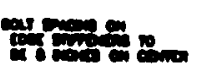
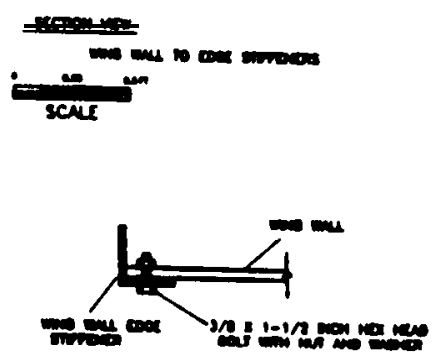

DETAL E STOPLOG SPECIFCATONS

$$
\text { andien }
$$

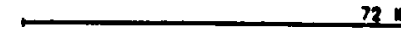

inT
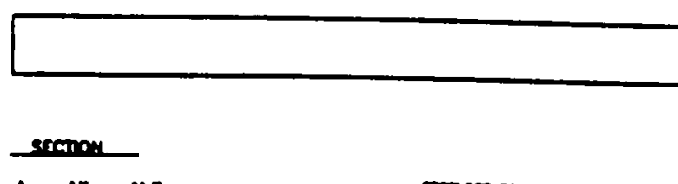

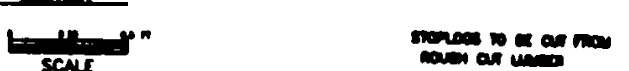

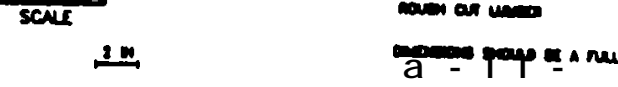

..

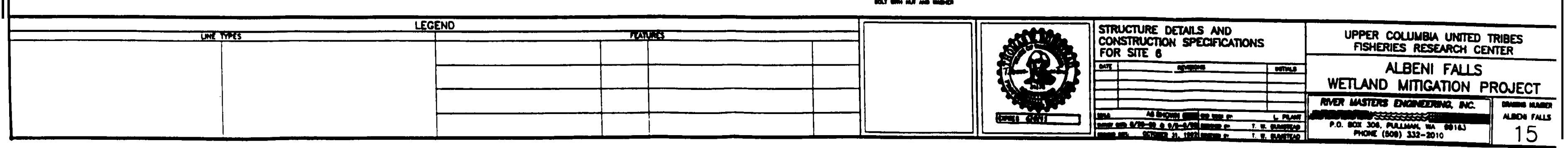

